\title{
O trabalho do enfermeiro na Saúde Indígena: desenvolvendo competências para a atuação no contexto intercultural
}

\author{
Versão Original
}

Dissertação apresentada ao Programa de pós graduação em Saúde pública da Faculdade de Saúde Pública da Universidade de São Paulo para obtenção do título de Mestre em Ciências.

Área de concentração: Saúde Pública

Orientador: Profa. Dra. Cleide Lavieri Martins

São Paulo 
Autorizo a reprodução e divulgação total ou parcial deste trabalho, por qualquer meio convencional ou eletrônico, para fins de estudo e pesquisa, desde que citada a fonte.

Catalogação da Publicação

Biblioteca/CIR: Centro de Informação e Referência em Saúde Pública

Faculdade de Saúde Pública da Universidade de São Paulo

Dados fornecidos pelo(a) autor(a)

Martins, Juliana Cláudia Leal

o trabalho do enfermeiro na Saúde Indígena:

desenvolvendo competências para a atuação no contexto

intercultural / Juliana Cláudia Leal Martins;

orientadora Cleide Lavieri Martins. -- São Paulo, 2017. $174 \mathrm{p}$.

Dissertação (Mestrado) -- Faculdade de Saúde Pública da Universidade de São Paulo, 2017.

1. Enfermagem. 2. Trabalho. 3. Saúde indígena. 4. Competência profissional. 5. Interculturalidade. I. Lavieri Martins, Cleide, orient. II. Título. 


\section{AGRADECIMENTOS}

Agradeço à minha família pelo apoio, incentivo e compreensão nos momentos em que estive mais distante envolvida com esta empreitada tão sedutora.

Aos indígenas, em especial os povos do Xingu, que tanto têm me ensinado e que, com tanta tranquilidade e sutileza, me colocam em um desassossego necessário para refletir sobre minha forma de ser e estar neste mundo.

Aos coordenadores do Projeto Xingu Sofia, Douglas e Lavínia que me proporcionaram a experiência de contato com a diferença de forma tão intensa e gratificante.

Aos amigos do Projeto Xingu pela convivência, amizade e a oportunidade de dividir momentos tão singulares, marcados por sentimentos diversos.

À querida professora Cleide, minha orientadora, pela acolhida, compreensão, ensino e, sobretudo, pelo respeito com as particularidades do meu processo de aprendizado e produção.

Aos profissionais, companheiros enfermeiros da saúde indígena, que colaboraram com a pesquisa e se dispuseram a compartilhar parte de suas vivências com tanto entusiasmo e satisfação. 


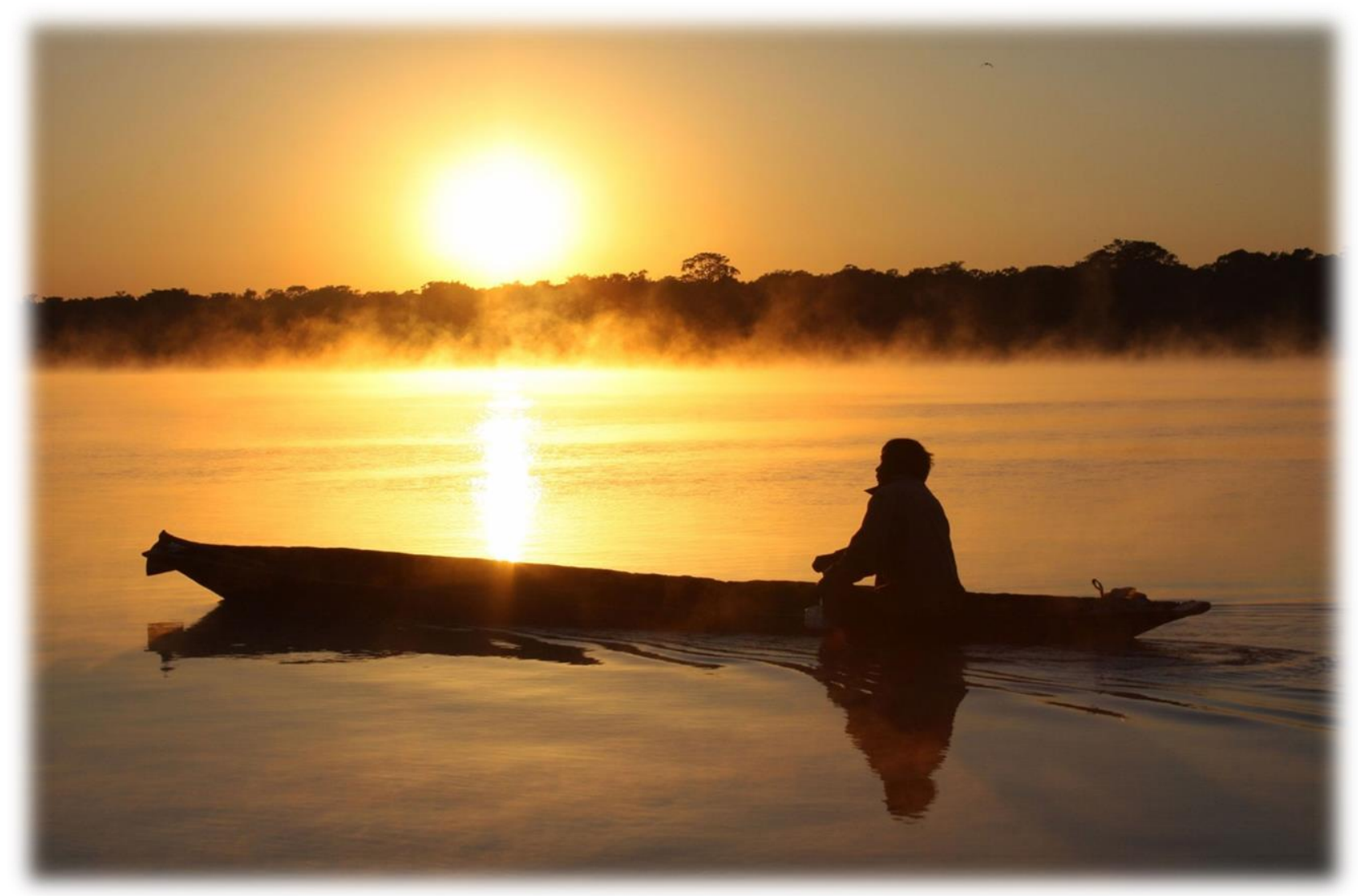

Foto: Hélio Mello.

"Aceitando a existência do Outro, nós vamos aprendendo a reconhecer no mundo um lugar de muitos povos. A nossa casa comum. Onde alguns chegaram primeiro."

Aílton Krenak 
Martins, J. C. L. O trabalho do enfermeiro na Saúde Indígena: desenvolvendo competências para a atuação no contexto intercultural. 2017. Dissertação Faculdade de Saúde Pública da Universidade de São Paulo, 2017.

\section{RESUMO}

Introdução: $O$ trabalho em saúde indígena tem como característica marcante a interculturalidade. O locus da prática dos profissionais é o contexto intercultural. A atuação nesse espaço de trabalho exige conhecimentos e competências que, muitas vezes, não são abordados durante a formação acadêmica. É também escassa a oferta de cursos após a graduação. $O$ foco deste estudo foi a compreensão e a análise das possibilidades de aprendizagem do enfermeiro a partir da vivência do trabalho no interior das áreas indígenas. Para isso, considerou-se a realidade concreta do trabalho como um potencial espaço de aprendizado, fortemente marcado pela interculturalidade. Objetivo: Analisar a vivência do trabalho de saúde dentro do território indígena como um espaço potencial de aprendizagem para que 0 enfermeiro qualifique a sua prática profissional voltada para a atuação neste contexto intercultural. Método: Trata-se de um estudo descritivo de abordagem qualitativa do tipo estudo de caso. O campo do estudo foi o Distrito Sanitário Especial Indígena (DSEI) Xingu e os sujeitos da pesquisa foram os enfermeiros que nele atuam. Os dados primários foram obtidos por meio de entrevistas semiestruturadas que abordaram a prática profissional e 0 processo de aprendizagem tendo como referência o trabalho no interior da terra indígena. A análise do material empírico foi realizada através da técnica de análise de conteúdo e com o apoio de conceitos do campo da antropologia e da educação tais como: competência profissional, aprendizagem significativa e interculturalidade. Resultados: A partir da inserção no serviço, os enfermeiros iniciam um processo de aprendizado que segue impulsionado cotidianamente pelas situações vivenciadas no trabalho e que tem os indígenas como principais mediadores. Aos poucos, os profissionais aprendem a identificar e mobilizar os recursos necessários para uma atuação profissional mais competente que atenda às demandas do contexto. A reprodução de práticas e atitudes é a principal estratégia utilizada pelos profissionais para lidar com as dificuldades. Dentre os elementos que compõem a competência para o trabalho nesse campo, se destacam as atitudes na relação com os indígenas e suas práticas. As representações e concepções trazidas pelos profissionais interferem na atuação profissional. A interculturalidade se mostra como fator inerente que caracteriza o contexto e as demandas que são colocadas aos profissionais que nele atuam. O distanciamento da gestão do DSEI faz com que tanto o processo de aprendizado quanto o desenvolvimento de competências ocorram de maneira autodirigida. Conclusões: $O$ perfil da atuação profissional do enfermeiro ganha forma, quase que exclusivamente, a partir de referências encontradas dentro da 
área indígena contribuindo para a consolidação de um modelo de atenção distante do proposto nas diretrizes políticas.

Palavras chave: Enfermagem. Trabalho. Saúde Indígena. Atenção Básica em Saúde. Competência Profissional. Interculturalidade. 
Martins, J. C. L. The work of nurses in Indigenous Health: developing competencies for action in the intercultural context. 2017. Dissertation - Faculdade de Saúde Pública, USP, São Paulo, 2017.

\section{ABSTRACT}

Introduction: The work in Indigenous Health is characterized by interculturality. The locus of practitioners' practice is the intercultural context. Acting in this workspace requires knowledge and skills that are often not addressed during academic education. The offer of courses after graduation is also scarce. The focus of this study was the understanding and analysis of nurses' learning possibilities based on the experience of work within indigenous areas. For this, the concrete reality of work was considered as a potential learning space, strongly marked by interculturality. Objective: To analyze the experience of health work within indigenous lands as a potential learning space for nurses to qualify their professional practice geared towards acting in this intercultural context. Method: This is a descriptive study of a qualitative approach of the case study type. The field of study was the Indigenous Special Sanitary District (DSEI) Xingu and the research subjects were the nurses who work in it. The primary data were obtained through a semi structured interview that approached the professional practice and the learning process having as reference the work in indigenous land. The analysis of the empirical material was carried out through the technique of content analysis and with the support of concepts of the field of anthropology and education, such as: professional competence, meaningful learning and interculturality. Results: As from the insertion in the service, the nurses begin a learning process that continues driven daily by the situations experienced in the work and that has the indigenous people as main mediators. Professionals are gradually learning to identify and mobilize the resources needed for more competent professional action that meets the demands of the context. Reproduction of practices and attitudes is the main strategy used by practitioners to deal with difficulties. Among the elements that compose the competence for the work in this field, the attitudes in relation with the natives and their practices stand out. The representations and conceptions brought by the professionals interfere in the professional performance. Interculturality shows itself as an inherent factor that characterizes the context and the demands that are presented to the professionals who work in it. The distance from the DSEI management makes both the learning process and the development of competencies occur in a selfdirected way. Conclusions: The profile of nurses' professional performance is shaped, almost exclusively, from references found within the indigenous area, contributing to the consolidation of a model of attention that is far from that proposed in the political guidelines.

Keywords: Nursing. Work. Health of Indigenous Peoples. Primary Health Care. Professional Competence. Interculturality. 


\section{APRESENTAÇÃO}

As motivações para o desenvolvimento deste trabalho vêm da minha experiência pessoal de atuação na saúde indígena, que se iniciou há pouco mais de onze anos. Durante a maior parte deste período, atuei como enfermeira integrante das Equipes Multidisciplinares de Saúde Indígena do Distrito Sanitário Especial Indígena Xingu. O apoio de profissionais experientes e o aporte teórico sobre temas importantes relacionados à antropologia, epidemiologia e educação foram decisivos para amenizar as estranhezas e conflitos vivenciados em minha inserção neste campo de trabalho tão específico além de permitir que eu prosseguisse atuando de forma mais qualificada e reflexiva.

A experiência de trabalho na saúde indígena me aproximou da formação profissional em saúde. Dentro de área indígena, além de desenvolver atividades características da atenção básica à saúde, atuei como educadora na formação de profissionais indígenas para o trabalho em saúde. Realizei também a inserção e acompanhamento em serviço de profissionais de enfermagem recém-ingressados no trabalho. Estas atividades de formação reforçaram a viabilidade e a necessidade de reflexão sobre o cotidiano do trabalho nas áreas indígenas como um espaço de formação.

Nos últimos cinco anos, minha atuação dentro das áreas indígenas se restringiu à participação em ações de apoio matricial e em atividades de formação de diferentes modalidades voltadas para os profissionais que atuam na saúde indígena, especialmente os que trabalham dentro das terras indígenas. Também tenho intensificado e qualificado minha participação na formação acadêmica de profissionais através das atividades: tutoria e docência no Curso de Especialização em Saúde Indígena à distância, ofertado pela Universidade Aberta do SUS (UNASUS), e preceptoria dos alunos do $5^{\circ}$ ano de medicina e do $3^{\circ}$ ano de enfermagem da Universidade Federal de são Paulo no módulo de Saúde Indígena da disciplina de Saúde Coletiva. As atividades de tutoria no curso de especialização têm me colocado em contato com uma diversidade de realidades de trabalho da saúde indígena. Através das atividades de tutoria, em especial o acompanhamento sistemático da participação dos alunos, pude perceber que muitos deles 
desenvolvem uma prática profissional pouco reflexiva e pouco sistematizada. São profissionais de saúde de diversas categorias, em geral, pouco preparados evidenciando as lacunas da formação acadêmica e o desafio da formação de profissionais já inseridos no Subsistema de Saúde Indígena. Nas atividades com os alunos de graduação ficou perceptível o quanto o universo indígena ainda é pouco abordado na formação acadêmica.

Estas experiências alimentaram o minha vontade e necessidade de aprofundar conhecimentos e amadurecer reflexões sobre a articulação entre formação profissional e realidade do trabalho em saúde dentro de área indígena. O olhar direcionado aos enfermeiros que compõem as equipes de campo decorre de minha formação profissional e experiência pessoal nesse espaço de trabalho.

O estudo foi pensado e desenhado a partir de interrogações que permeavam minhas reflexões e me instigaram a pesquisar:

$\checkmark$ O que leva o enfermeiro a atuar na saúde indígena? Qual o sentido do trabalho na saúde indígena?

$\checkmark$ Quais são os principais estranhamentos e conflitos que o enfermeiro vivencia quando inicia a sua atuação?

$\checkmark$ O que o enfermeiro que atua na saúde indígena considera importante aprender para atuar neste contexto?

$\checkmark$ Quais as alternativas que o profissional encontra para sanar as lacunas de sua formação quando está na prática? Quais atores se fazem presentes nesse processo?

$\checkmark$ Considerando a vivência do trabalho nas terras indígenas, quais os caminhos para a construção de novos conhecimentos e para 0 desenvolvimento de competências?

Ao longo do desenvolvimento do estudo, as questões foram amadurecendo. Algumas foram respondidas e outras se desdobraram em novas inquietações cujas elucidações demandariam uma maior aproximação expondo os limites de alcance do presente estudo. As reflexões suscitadas neste percurso geraram aprendizados também enquanto formação profissional da própria pesquisadora. 
O objeto central do estudo foi o processo de aprendizagem dos enfermeiros que atuam nas áreas indígenas a partir da prática. $\mathrm{O}$ material coletado encerrou uma riqueza de informações que tornou possível traçar e analisar o caminho percorrido por esses profissionais rumo à qualificação a partir da vivência do trabalho.

A análise dos dados foi apoiada por conceitos do campo da educação e da antropologia. Ao final, foram levantadas informações que podem contribuir para o desenvolvimento de estratégias de qualificação voltadas para o trabalho neste contexto e em contextos similares.

$\mathrm{Na}$ Introdução são apresentados conteúdos considerados relevantes dentro do tema e que contribuem para uma melhor contextualização do objeto do estudo. A abordagem sobre os povos indígenas no Brasil na atualidade implica em revisitar alguns temas importantes inscritos na história. É sob essa perspectiva de resgate histórico que são apresentadas a relação entre os povos indígenas, o Estado e a sociedade brasileira, a organização da assistência à saúde desses povos na atualidade e a presença da enfermagem neste campo de atuação.

A Introdução também foi considerada o espaço mais adequado para uma apresentação mais detalhada do campo de estudo, o Parque Indígena do Xingu (PIX). O ponto de partida é um breve histórico da atenção à saúde nesta terra indígena marcada fortemente pela atuação da Universidade Federal de São Paulo (UNIFESP). Em seguida são apresentadas a estrutura e a organização da atenção à saúde no PIX nos dias de hoje, com o foco no trabalho dentro da terra indígena. $A$ descrição do contexto do trabalho e da atuação da equipe tem como propósito aproximar o leitor com esta realidade tão singular.

O perfil dos participantes da pesquisa é apresentado no início da seção Resultados e Discussão. Optou-se por uma apresentação descritiva com o objetivo de organizar melhor as informações sobre o itinerário formativo e profissional de cada um com foco na experiência de trabalho na saúde indígena.

Os resultados da análise são organizados em tópicos e subtópicos que tratam de cinco temas centrais: 1 - os motivos que levam o profissional a trabalhar na saúde indígena; 2- a realidade do trabalho no contexto intercultural; 3- os caminhos para 
construção de competências; 4- as concepções a partir da experiência e 5- o imperativo da interculturalidade. 


\section{SUMÁRIO}

1 - INTRODUÇÃO

1.1 - A SINGULARIDADE DO TRABALHO NA SAÚDE INDÍGENA ..................................... 17

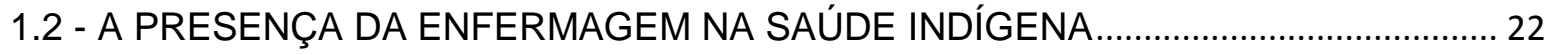

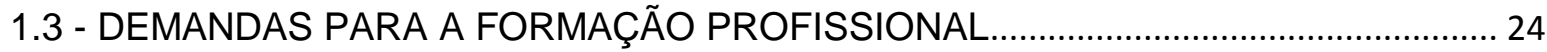

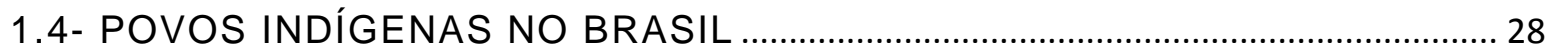

1.5- A ATENÇÃO À SAÚDE DOS POVOS INDÍGENAS NO BRASIL E O

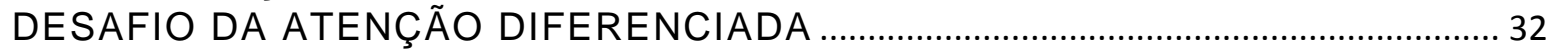

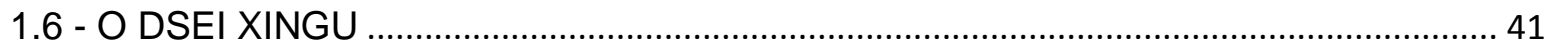

1.6.1 - Histórico da Assistência à Saúde no Parque Indígena do Xingu ............................ 41

1.6.2 - Estrutura e Organização do Serviço no DSEI Xingu ................................................. 44

1.6.3 - O Trabalho Dentro da Área Indígena e a Atuação da Universidade ...................... 50

1.7 - A NOÇÃO DE COMPETÊNCIA E A APRENDIZAGEM SIGNIFICATIVA NA SAÚDE

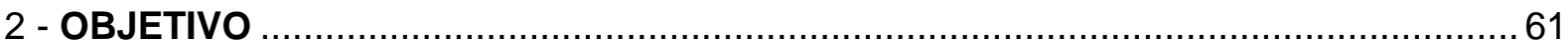

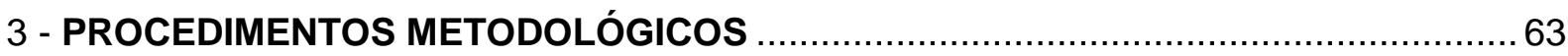

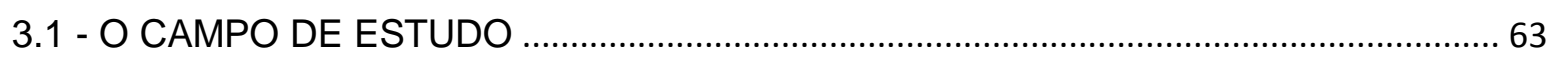

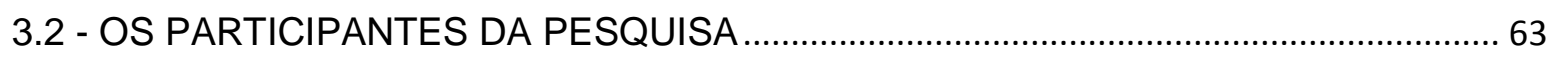

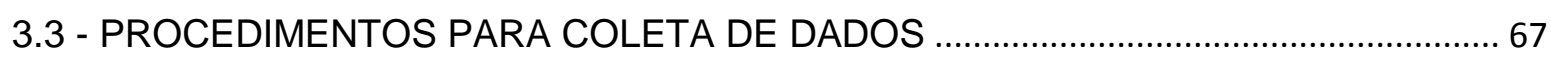

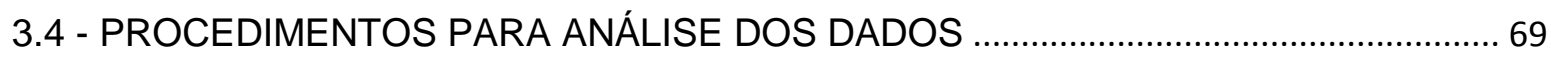

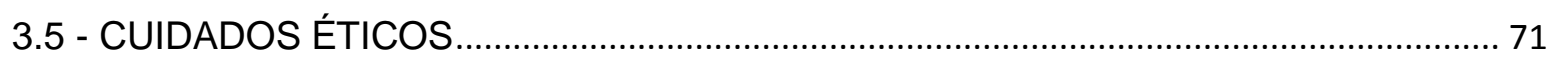

4 - RESULTADOS E DISCUSSÃO

4.1 - OS PARTICIPANTES E SUAS TRAJETÓRIAS ATÉ O TRABALHO NA SAÚDE INDÍGENA

4.2 - PORQUE EU VENHO E O QUE TRAGO COMIGO: MOTIVAÇÕES, EXPECTATIVAS E CONCEPÇÕES NA CONSTRUÇÃO DE UM SENTIDO PARA O TRABALHO NA SAÚDE INDÍGENA.

4.3 - DAS SURPRESAS NO ENCONTRO COM A DIFERENÇA AOS DESAFIOS NA IMERSÃO NO CONTEXTO INTERCULTURAL.

4.3.1 - Surpresas no Contato com a Realidade: Ajustes Entre o Imaginário e o Real.... 92

4.3.2 - A Imersão na Área Indígena 99

4.4 - RUPTURAS, PERMANÊNCIAS E NOVAS CONSTRUÇÕES: CONCEPÇÕES DOS PROFISSIONAIS A PARTIR DA EXPERIÊNCIA.

4.4.1 - O Trabalho Dentro de Área e a Atuação dos Enfermeiros ...................................... 107

4.4.2 - Quem são os indígenas sob o ponto de vista dos profissionais ........................... 114

4.5 - OS CAMINHOS PARA CONSTRUÇÃO DE COMPETÊNCIA ..................................... 115 
4.5.1 - Como, Com Quem e O Que se Aprende: Saber Fazer e Saber Ser 116

4.5.2 - O Espaço e o Tempo do Aprendizado

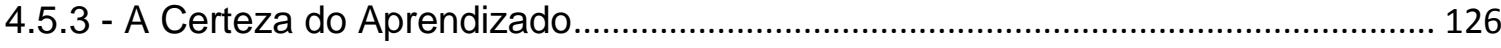

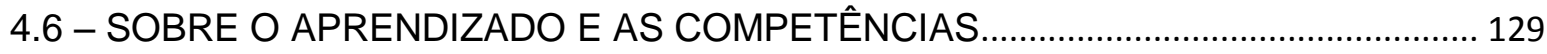

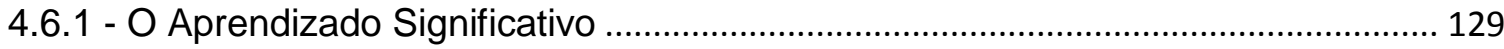

4.6.2 - Os Elementos que Compõem a Competência Profissional no Trabalho em Saúde no Xingu 130

4.6.3 - O Papel da Gestão do DSEI na Formação 134

4.7 - O IMPERATIVO DA INTERCULTURALIDADE E OS LIMITES DO DIÁLOGO INTERCULTURAL 137

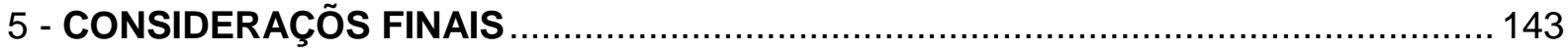

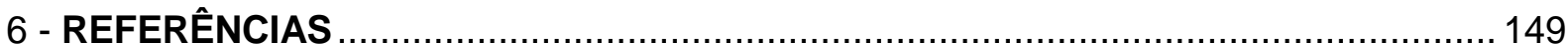

ANEXOS

Anexo A - Roteiro para entrevista semiestruturada …................................................... 165

Anexo B - Percurso adotado para a definição dos temas de análise ................................. 168

Anexo C - Termo de anuência do Conselho Distrital de Saúde Indígena do DSEI Xingu .. 169

Anexo D - Termo de Consentimento Livre e Esclarecido ................................................. 170

Anexo E - Autorização para uso de dados do DSEI Xingu ........................................... 173

Anexo F - Autorização para utilização de dados do Projeto Xingu/ UNIFESP .................. 174 


\section{LISTA DE MAPAS}

Mapa 1 - Distribuição dos 34 Distritos Sanitários Especiais Indígenas. .36

Mapa 2 - Abrangência do DSEI* Xingu, 2016.

Mapa 3 - Distribuição dos enfermeiros do DSEI* Xingu segundo local de atuação, 2016.

Mapa 4 - Distribuição dos participantes da pesquisa segundo local de atuação, DSEI* Xingu 2016. 66

\section{LISTA DE TABELAS}

Tabela 1 - Distribuição da população da abrangência do DSEI* Xingu, dezembro de 2016.

\section{LISTA DE QUADROS}

Quadro 1 - Força de trabalho no DSEI* Xingu, 2016 .48

Quadro 2 - Definições dos elementos que compõem a competência profissional....57 


\section{LISTA DE SIGLAS}

AIS Agente Indígena de Saúde

AEI Auxiliar de enfermagem Indígena

CASAI Casa de Saúde do Índio

CIMI Conselho Indigenista Missionário

CISI Comissão Intersetorial de Saúde Indígena

CNS Conselho Nacional de Saúde

CNSI Conferência Nacional de Saúde Indígena

CONDISI Conselho Distrital de Saúde Indígena

DSEI Distrito Sanitário Especial Indígena

EMSI Equipe Multidisciplinar de Saúde Indígena

EPM Escola Paulista de Medicina

EVS Equipes Volantes de Saúde

FUNAl Fundação Nacional do Índio

FUNASA Fundação Nacional de Saúde

IBGE Instituto Brasileiro de Geografia e Estatística

ISA Instituto Socioambiental

NASF Núcleo de Apoio à Saúde da Família

NASI Núcleo de Apoio à Saúde Indígena

OIT Organização Internacional do Trabalho

OMS Organização Mundial da Saúde

PIX Parque Indígena do Xingu

PMMB Programa Mais Médicos para o Brasil

PSF Programa de Saúde da Família

SASI-SUS Subsistema de Atenção à Saúde Indígena-SUS

SESAl Secretaria Especial da Saúde Indígena

SGTES Secretaria de Gestão do Trabalho e Educação na Saúde

SIASI Sistema de Informação da Atenção à Saúde Indígena

SPDM Associação Paulista para o Desenvolvimento da Medicina

SPI Serviço de Proteção ao Índio

SUS Sistema Único de Saúde 
SUSA Serviço de Unidades Sanitárias Aéreas

UBS Unidade Básica de Saúde

UNIFESP Universidade Federal de São Paulo 
INTRODUÇÃO

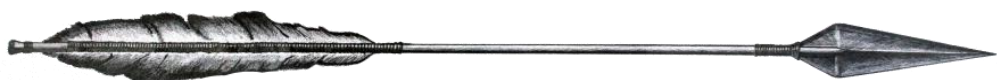




\section{1 - INTRODUÇÃO}

\section{1 - A SINGULARIDADE DO TRABALHO NA SAÚDE INDÍGENA}

Mexer com culturas exige artes e competências refinadas.

Miguel Arroyo

A saúde indígena tem se caracterizado como um campo de atuação específico dentro da saúde coletiva tendo como característica mais expressiva a interculturalidade. O locus da prática dos profissionais da saúde voltada a população indígena é o contexto intercultural, um espaço onde dois sistemas de cura com concepções e práticas diferentes são postos a dialogar. De um lado o sistema médico ocidental com seus saberes e práticas ancorados no paradigma da racionalidade científica. Do outro, os sistemas indígenas de saúde com suas práticas de cuidado e cura representantes de um saber não validado e inscritas num universo cultural distinto. (NOVO, 2011). Neste espaço de interlocução, "o que se encontra é a coexistência de duas sociedades, de dois sistemas médicos distintos e em franca desigualdade de poder" (MENDONÇA, 2005, p.240).

O reducionismo do adoecimento em sua dimensão biológica e individual, traço marcante do modelo biomédico, se contrapõe ao paradigma indígena, no qual o processo de adoecimento e cura é pensado como sendo sociocultural. Nas concepções indígenas, o adoecimento é um evento que incide sobre a vida das pessoas em relação íntima com o corpo social e tem determinações e implicações mais coletivas que individuais, extrapolando em muito a capacidade explicativa da biomedicina (LANGDON, 1999; GARNELO e BUCHILLET, 2006).

Neste contexto, o profissional de saúde, que é, ao mesmo tempo, produto e agente multiplicador do discurso biomédico, vivencia uma relação conflituosa. Em todos os momentos do seu cotidiano, o profissional é incitado a repensar suas práticas, concepções, valores éticos e morais. Para Fernandes (2010, p.36) "a decisão pelo trabalho na saúde indígena leva o trabalhador a pensar e refletir sobre a própria cultura". 
Nesse caminho, a antropologia parece ser o fio condutor. Ancorados na Teoria do Cuidado Cultural de Leininger, Vilelas e Janeiro (2012) apontam a Competência Cultural como indispensável aos enfermeiros frente a pluralidade étnico cultural estabelecida em Portugal a partir das alterações nos fluxos migratórios ocorrida nas últimas décadas. Nesta teoria, a competência cultural é entendida como "a capacidade de compreender as diferenças culturais, a fim de prestar cuidados de qualidade a uma diversidade de pessoas" (LEININGER, 2002 citado por VILELAS e JANEIRO, 2012, p.121).

[...] os enfermeiros com competência cultural melhoram a eficácia na capacidade de comunicação, apreciações culturais e aquisição de conhecimentos relacionados com as práticas de saúde de diferentes culturas. [...] a definição mais abrangente de competência cultural na prática de enfermagem é considerá-la um processo em curso com o objetivo de alcançar a capacidade de trabalhar efetivamente com pessoas culturalmente diferentes (VILELAS e JANEIRO, 2012, p.121).

Na saúde indígena, a sensibilidade cultural, os conhecimentos antropológicos, a postura política, a capacidade de escuta, diálogo e negociação são "ferramentas" indispensáveis à atuação dos profissionais (MENDONÇA, 2013). É de fundamental importância aos profissionais o conhecimento de conceitos antropológicos como "cultura' e "relativismo cultural", além do entendimento dos valores, representações e práticas que compõem o sistema simbólico de saúde de cada etnia em particular. Importante também conhecer as regras e as etiquetas sociais que devem ser seguidas. Este conhecimento ultrapassa a perspectiva simplificada do "respeito à diferença" tornando-se condição necessária par a constituição de uma relação respeitosa e produtiva com os indígenas e suas práticas, rumo a melhoria das condições de saúde (LANGDON, 1999, 2004; JUNQUEIRA, 2004; GARNELO e BUCHILLET, 2006; LORENZO, 2011).

O desenvolvimento desta competência cultural resulta da disposição dos profissionais de saúde para despirem-se de seus valores e entender a cultura indígena, relativizar seu conhecimento biomédico, desconstruir práticas etnocêntricas, demonstrar respeito à cultura indígena e interesse pela história do povo que irá atender (RODRIGUES et al., 2015, p.10). 
Para além da dimensão cultural, o contexto do trabalho em saúde indígena impõe aos profissionais outras demandas não menos importantes. O espaço onde se dá o encontro intercultural é o cotidiano de trabalho que, em muitas situações, torna-se também o cotidiano de vida do profissional. Em muitas regiões do país, nas áreas de mais difícil acesso como na região amazônica, os profissionais experimentam uma intensa imersão no trabalho, permanecendo por longos períodos dentro das terras indígenas, às vezes, mais de trinta dias. Dessa forma, passam a integrar as equipes e a atuar em um processo de trabalho com características muito particulares. Nesse mergulho, os profissionais são impelidos a experimentarem novas relações interpessoais e sociais, e adaptar-se a outros padrões de privacidade e conforto diferentes do ambiente urbano. Os longos períodos de afastamento do seu meio social e familiar podem gerar desgaste e o conflito experimentado no trabalho não é apenas de ordem cultural, mas, também laboral e emocional.

O processo de trabalho compreende a forma como este é realizado e pode ser entendido a partir de seus quatro elementos constitutivos principais: o objeto, a finalidade, os agentes e os meios. Com o objetivo de atingir uma finalidade, os agentes atuam sobre um objeto utilizando diversos meios. Esses elementos são constituintes de qualquer processo de trabalho ganhando uma conformação diferente no trabalho em saúde. No trabalho em saúde, o objeto são as necessidades de saúde, alvo da ação de uma pluralidade de agentes que fazem uso de instrumentos diversos, com a finalidade de modificar estas necessidades, de forma a satisfazer o usuário (GONÇALVES, 1992; SANNA, 2007).

Nogueira (2000) destaca que o trabalho em saúde é um serviço marcado por uma relação interpessoal intensa que se constitui como decisiva e necessária para a sua efetividade. Apesar de existir uma intencionalidade e uma direcionalidade, o processo será caracteriza como abstrato e singular, considerando as subjetividades envolvidas no encontro entre profissionais e usuários. $O$ autor também salienta a participação ativa do usuário, o consumidor final, como essencial para o sucesso da ação, fato que agrega um caráter singular ao ato.

Para Merhy (1997), essa dinâmica de produção e consumo acontece de forma muito peculiar na saúde suscitando um caráter dinâmico e permanentemente instituinte ao processo de trabalho. $O$ encontro entre usuário e profissional é o local de 
intercessão, onde se opera o trabalho em sua forma mais viva. É nesse espaço de encontro, do trabalho vivo em ato, conforme proposto por Merhy $(1997)^{1}$, que o profissional experimenta na saúde indígena a vivência da interlocução e do choque de saberes e fazeres.

Na saúde indígena, a finalidade do trabalho - produção de saúde - adquire novos contornos, sob a ótica das concepções e práticas tradicionais indígenas, perspectivas muito diferentes daquelas do modelo biomédico. As demandas de saúde são determinadas social, temporal e historicamente nas formas de contato com a sociedade nacional (BRASIL, 1986). Nesse sentido, não é aconselhável ao profissional ignorar a história de contato, bem como, o contexto social, político e econômico, que trazem implicações diretas sobre as condições de vida e de saúde desses povos. (IDS-SSL-CEBRAP, 2009; RODRIGUES et al., 2015).

Os profissionais também precisam aprender a dialogar e a atuar com outros atores e práticas reconhecendo a sua legitimidade. Dentro das equipes, o Agente Indígena de Saúde (AIS) é o principal representante desse grupo. Definido, com frequência, como o interlocutor entre a equipe de saúde (da qual é integrante) e a comunidade, - AIS ocupa uma posição muito singular nesse processo de trabalho. Ao mesmo tempo em que é um representante legítimo da cultura de seu povo, é também um profissional em formação num processo de apropriação de conhecimentos e práticas da medicina ocidental. É portanto representante e porta voz de duas racionalidades, precisa responder às demandas e expectativas de cada uma e, com frequência, é chamado a atuar na intermediação de conflitos entre ambas.

Parteiras, xamãs, rezadores, pajés e outros especialistas tradicionais ${ }^{2}$ são os detentores dos conhecimentos e práticas tradicionais de cuidado além de se constituírem como figuras sempre presentes no itinerário terapêutico dos pacientes. As práticas tradicionais também se fazem presentes no autocuidado desenvolvido no âmbito familiar.

\footnotetext{
${ }^{1}$ Merhy refere-se a Trabalho Vivo em Ato como o trabalho instituinte, que está em ação, dentro do processo de trabalho. Na saúde o trabalho vivo em ato corresponde ao trabalho do profissional no momento em que é realizado, na produção de cuidado.

${ }^{2}$ A expressão "especialistas tradicionais" está presente na Política Nacional de Atenção à Saúde dos Povos Indígenas (PNASPI) e é utilizada para se referir aos indígenas que realizam práticas de cuidado e cura tradicionais no universo cultural de seu povo.
} 
As situações de conflito ocorridas no trabalho estão associadas, em geral, à necessidade de diálogo e negociação com os especialistas tradicionais e com as famílias para tomada de decisões importantes, especialmente, nas situações de urgências e de emergência.

Dentro das áreas indígenas os profissionais também sentem o impacto do espaço físico para o trabalho. De forma geral, a infraestrutura para o trabalho é insuficiente, marcada pela falta de equipamentos e de materiais necessários. Nas aldeias, nem sempre é possível garantir espaço físico específico e adequado para a realização de procedimentos. Outro fator a ser considerado é a fragilidade dos limites legais da atuação profissional no trabalho dentro de área indígena, como apontada na III Conferência Nacional de Saúde Indígena (CNSI).

[...] as condições de trabalho na atenção à saúde nas aldeias levam, com certa frequência, à ruptura dos limites de atuação legalmente estabelecidos para cada categoria, tornando os profissionais vulneráveis a sanções dos conselhos que regulamentam as profissões (FUNASA, 2001, p.16).

Nesta interlocução entre os profissionais de saúde e as culturas indígenas, a subjetividade se faz presente de forma inevitável. Para além das concepções e valores agregados na formação acadêmica, o profissional carrega para sua prática convicções e princípios pessoais elaborados e adquiridos ao longo da vida. Tudo que vivencia e observa passa pelo crivo de seu código moral particular e de sua ética profissional. Dessa forma, não surpreende que a atuação profissional se desenvolva permeada por preconceito sobre os indígenas, fruto do senso comum. A partir dessa reflexão, torna-se pertinente interrogar: Quais concepções os profissionais carregam sobre os povos indígenas? Como entendem o seu trabalho neste campo de atuação? Por que, para que e como os profissionais se inserem neste espaço de trabalho tão específico? Como os profissionais enfrentam as demandas colocadas pelo trabalho no contexto intercultural? 


\section{2 - A PRESENÇA DA ENFERMAGEM NA SAÚDE INDÍGENA}

A presença sistemática dos profissionais de enfermagem na saúde indígena se inicia juntamente com a primeira tentativa de assistência estruturada dentro das áreas indígenas, na década de 1970, no contexto da criação do serviço de Equipes Volantes de Saúde (EVS). Em relatórios de trabalho das $E S^{3}$ é possível identificar que o trabalho dentro das terras indígenas era desenvolvido pelos atendentes de enfermagem que, em algumas situações, contavam também com o auxílio de agentes de saúde e indígenas colaborando na realização das atividades. A assistência dentro de área indígena caracterizava-se pela realização de atividades como curativos, assistência ao parto e dispensação de medicações básicas. A formação e a supervisão dos profissionais ocorriam durante as viagens das EVS a campo, podendo ser realizada por todos os profissionais integrantes da equipe. Ao profissional enfermeiro integrante das EVS cabia a participação nas viagens com a tarefa principal de realizar a imunização. Apesar de pouco descritivos, é possível encontrar em alguns desses documentos referências sobre questões importantes do trabalho, como as relações entre as equipes e os indígenas e a necessidade de permanência, dentro das áreas indígenas, de profissionais devidamente preparados.

Com a implantação do Subsistema de Atenção à Saúde Indígena (SASI-SUS) em 1999, o enfermeiro passa a estar mais presente nas áreas indígenas integrando as Equipes Multidisciplinares de Saúde Indígena (EMSI). Essa mudança na fixação de profissionais e na orientação do modelo assistencial vem acompanhada de uma nova proposta para atuação do enfermeiro, coerente com uma concepção mais ampliada da atenção à saúde que extrapola os limites do puro assistencialismo emergencial.

O que se constata é que o enfermeiro se estabeleceu como um profissional significativamente expressivo na saúde indígena espelhando o que já é observado

\footnotetext{
${ }^{3}$ Relatórios de Trabalho das Equipes Volantes de Saúde disponibilizados pelo Serviço de Gestão Documental (SEDOC) da FUNAI. Os documentos físicos foram consultados em novembro de 2015 na sede da FUNAI em Brasília e, posteriormente, disponibilizados pelo serviço em versão digitalizada.
} 
na saúde pública. Contudo, o perfil de atribuições do enfermeiro na saúde indígena ainda não foi apresentado em nenhum documento normativo.

A enfermagem é uma parcela do trabalho da saúde. Nesta perspectiva, como integrantes da EMSI, os profissionais de enfermagem são parte de um trabalho coletivo e colaborativo desenvolvido junto com os demais profissionais da equipe.

$\mathrm{Na}$ prática, reproduzindo o que é observado nos outros espaços de atuação, no trabalho dentro de área indígena o enfermeiro assume um papel gerenciador dentro da equipe se responsabilizando pela organização do serviço. Além disso, algumas atividades figuram quase como que exclusivas desse profissional, como a formação dos profissionais indígenas e a realização de atividades educativas.

É a partir das dimensões do processo de trabalho efetivadas em sua atuação no serviço, no trabalho vivo em ato, que o enfermeiro vivencia uma interação marcada pela interculturalidade e potencialmente conflituosa. Este contexto impõe a necessidade de aquisição competências que lhe permitam desenvolver a sua prática de forma mais qualificada.

Além das demandas colocadas pela interculturalidade, e as condições precárias de infraestrutura, muito comuns nas áreas indígenas, o enfermeiro também tem que enfrentar uma sobrecarga de trabalho, advinda da falta de profissionais médicos, especialmente nas regiões de mais difícil acesso. Nessas situações, com frequência o enfermeiro é demandado a realizar atividades que fogem a sua competência e para as quais não foi preparado como, por exemplo, elaborar diagnósticos clínicos, instituir tratamentos medicamentosos e assistir a partos com intercorrência. Silva (2014) observa que a competência cultural não é suficiente para o bom desempenho do trabalho do enfermeiro sendo também necessária a competência clínica. 


\section{3 - DEMANDAS PARA A FORMAÇÃO PROFISSIONAL}

Os profissionais de saúde precisam estar habilitados para reconhecer, refletir e dialogar com os modos de vida da comunidade indígena e respeitar as práticas de saúde tradicionais.

Esther Jean M Langdon

A formação de profissionais para o trabalho em saúde no Brasil tem sido tema de discussão desde a década de 1970. O movimento da Reforma Sanitária, na década de 1980, e a posterior criação do Sistema Único de Saúde (SUS), em 1990, reforçaram a demanda de reorientação da formação profissional. Tal demanda corresponde a um novo paradigma sobre as formas de pensar e produzir saúde, de acordo com o novo modelo assistencial e com a capacidade de promover a aproximação entre as instituições formadoras, as ações e os serviços.

Desde então, diferentes estratégias e políticas foram elaboradas com vistas a melhorar a formação profissional em nível acadêmico e a qualificação dos profissionais já inseridos no sistema de saúde. Programas de profissionalização, capacitação e qualificação profissional são iniciativas que compõe estas estratégias (BRASIL, 2004a).

$\mathrm{Na}$ última década, estas estratégias tomaram vigor com ações do Ministério da Saúde. Em 2003, foi criada a Secretaria de Gestão do Trabalho e da Educação na Saúde (SGTES) e no ano seguinte, em 2004, a Política de Educação Permanente em Saúde, entendida como a principal estratégia para a formação profissional para a atuação no SUS.

Enquanto política, a Educação Permanente tem por objetivo reordenar a formação profissional, de forma articulada às práticas dos serviços de saúde. Enquanto prática, a Educação Permanente é entendida como ensino/aprendizado, a partir de uma visão crítico-reflexiva sobre as vivências do cotidiano, apoiada nos conceitos de ensino problematizador e de aprendizagem significativa. $O$ trabalho é entendido como um espaço de aprendizagem (CECCIN e FERLA, 2008; BRASIL, 2007).

As demandas de formação profissional para o trabalho na saúde indígena são orientadas pelas especificidades deste campo de atuação, estando situadas no contexto maior da formação para o trabalho no SUS. 
A formação dos profissionais para o trabalho foi tema de discussão em todas as cinco Conferências Nacionais de Saúde Indígena. No que diz respeito aos não indígenas, é reconhecida a particularidade do contexto do trabalho, sendo defendida a necessidade de capacitação dos profissionais que compõe as EMSI visando a superação das lacunas da formação e a garantia de uma atuação profissional que atenda às demandas da atenção à saúde indígena em conformidade com a Política Nacional de Atenção à Saúde dos Povos Indígenas (PNASPI). As propostas e recomendações elaboradas nas conferências apontam a Educação Permanente como a principal estratégia para a formação (BRASIL, 1986; FUNASA, 1993, 2001, 2007; SESAI, 2014). Nelas, destacam-se aspectos como:

$\checkmark$ Programas de educação permanente voltados a todos os profissionais que atuam na saúde indígena, nos seus diversos serviços e níveis de atenção regionalizados e que contemplem as realidades locais;

\ecessidade e importância de articulação entre a gestão do Subsistema e entidades ou centros formadores;

\ Importância da capacitação inicial dos profissionais que ingressam no trabalho de campo;

$\checkmark$ Participação de especialistas tradicionais nos cursos de formação em especial os destinados aos profissionais de área;

$\checkmark$ Inclusão, nos programas de educação permanente, de temas como: antropologia, linguística, pedagogia e especificidades culturais.

As referências sobre a formação nas conferências vêm, com frequência, acompanhadas da discussão sobre o perfil profissional, necessidade de melhoria do vínculo trabalhista e a garantia de condições adequadas para o trabalho dentro de área.

Os critérios de admissão devem contemplar, além da habilitação técnica de cada categoria profissional, preocupações com: motivação, afinidade, e compromisso com a causa indígena, capacidade de se adaptar às condições de vida e trabalho na aldeia, de conviver e aceitar os costumes indígenas e se dispor ao aprendizado da língua indígena (FUNASA, 2001, P.15). 
O preparo dos profissionais é umas das diretrizes da PNASPI, sendo apontado como um ponto importante para a adequação das práticas sanitárias e efetivação da política, devendo, por isso, ser priorizado. Há destaque para a formação e capacitação dos Agentes Indígenas de Saúde (AIS), figura essencial no modelo de atenção. No processo de formação dos AIS, os profissionais não indígenas devem desempenhar o papel de instrutores/supervisores. Ao órgão gestor, cabe a responsabilidade pela capacitação de todos os profissionais, contando com a participação de instituições formadoras, de ensino e pesquisa. A PNASPI orienta também a formação em nível acadêmico e de profissionais que atuam nos diversos níveis de atenção. (FUNASA, 2002).

A formação profissional para atuação voltada à saúde indígena constitui ainda um desafio e a prática profissional tem sido reveladora das lacunas do processo formativo. O tema saúde indígena e conteúdos relacionados à antropologia são escassos nos currículos de graduação. Há também pouca oferta de cursos para os profissionais já formados (ATHIAS e MACHADO, 2001; LORENZO, 2011; OLIVEIRA, 2014).

Muitos profissionais de saúde são enviados para as terras indígenas sem orientações sobre o cotidiano em uma aldeia e sobre a prática no atendimento em saúde. São muito frequentes os relatos de vivências relacionadas aos estranhamentos e conflitos ocorridos neste espaço de trabalho tão específico.

A dinâmica do trabalho em campo também impossibilita a participação em cursos presenciais nos moldes e espaços formais de aprendizado. Isso faz com que a oportunidade de aprendizado se dê na prática, quando o profissional já se encontra inserido no trabalho, por meio da vivência.

No caso da saúde indígena, a formação de profissionais sempre ocorreu de modo espontâneo e autodidata. A maioria dos universitários buscava apoio teórico no campo da saúde coletiva e antropologia. A oferta de cursos formais de especialização e pósgraduação na área ainda é escassa, mas algumas universidades estão começando a incluir a temática em seus currículos de saúde coletiva (OLIVEIRA, 2014, p.5). 
Historicamente, as ações de formação e capacitação na saúde indígena não têm priorizado os trabalhadores não indígenas. Quando presentes, estas ações se caracterizaram pela descontinuidade, foco na biomedicina e nos programas de saúde e desconsideração pela diversidade sociocultural (DIHEL e PELLEGRINI, 2014).

Há um consenso sobre a importância da oferta de um aporte teórico prévio aos profissionais que ingressam no trabalho, contemplando especialmente conteúdos de antropologia. Contudo, não há um direcionamento sobre como isso pode ser feito. De forma geral, é comum o uso de termos como sensibilização, introdução, capacitação e treinamento para se referir à oferta de conteúdos teóricos e atividades práticas aos profissionais inseridos no trabalho.

Em estudo realizado no DSEI Manaus, Oliveira (2013) identificou, entre outras questões, que os conteúdos das capacitações destinadas aos enfermeiros das equipes de campo, correspondiam a adaptações de atividades desenvolvidas na realidade urbana, com enfoque na implantação e desenvolvimento de programas de saúde. Uma oferta muito distante das necessidades do trabalho com as populações indígenas e das especificidades locais.

A grande rotatividade nas equipes é outro fator que prejudica o processo de formação dos profissionais já inseridos no trabalho.

Pensar a formação para a atuação em saúde indígena implica em considerar uma variedade de atores, espaços e práticas que compõem este contexto de trabalho tão partícula e também a grande diversidade sociocultural dos povos indígenas em nosso país. Ao se considerar isso, decorrem as seguintes questões: É possível garantir uma formação prévia? Até que ponto o aporte de conhecimentos teóricos é suficiente? Quais as possibilidades de aprendizagem a partir da inserção no serviço? 


\section{4- POVOS INDÍGENAS NO BRASIL \\ A questão indígena nasceu com o descobrimento do Brasil, da América em geral, e
continuará a existir enquanto houver povos indígenas.}

Mércio Pereira Gomes

A visão sobre os indígenas como povos "inferiores" tem suas raízes no processo de colonização e na história da política escravocrata implantada no Brasil. Sob o olhar etnocêntrico dos portugueses, os indígenas foram classificados como social e culturalmente inferiores. Essa visão foi o gatilho que disparou um histórico de dominação e violência de todas as ordens. As epidemias, a escravização, as guerras de extermínio e espoliação de suas terras foram responsáveis pela depopulação e até a dizimação de alguns povos. Os indígenas nunca foram contemplados nos projetos nacionais, a não ser como força de trabalho ou um obstáculo a ser vencido. Sob essa ótica, o pertencimento dos indígenas à nossa sociedade, só poderia se dar pela via da dominação e assimilação. O ideário assimilacionista apoiava-se não nos argumentos que atribuíam condição de inferioridade a esses povos, como também, na certeza de que eles estariam condenados ao desaparecimento. Nesse caminho, o Estado em suas diferentes configurações e representações seguiu num esforço permanente de "captura" e dominação dos povos. De sua parte, os indígenas demonstraram sua capacidade de resistência, no constante e desigual embate travado com a nossa sociedade. Ocuparam, no entanto, o lugar menos privilegiado no desequilíbrio de forças (SANTOS et al., 2007; GOMES, 2012; CIMI, 2013b).

\footnotetext{
A relação que se estabeleceu entre os povos indígenas e os colonizadores, caracterizada pela profunda desigualdade de forças, gerou uma série de fatores que determinaram condições de subordinação e dependência. Entre esses fatores está o acesso à assistência à saúde (RODRIGUES, 2014, p.16).
}

Para Gomes (2012), a ambiguidade herdada das políticas indigenistas portuguesas, assim como os modelos econômicos adotados em nosso país desde a colonização, fizeram com que os órgãos responsáveis não dessem conta da missão de desenvolver políticas voltadas para a autonomia dos povos indígenas. Tampouco possibilitou garantias para a proteção desses povos frente às demandas dos 
grandes projetos políticos e econômicos nacionais e regionais, de caráter desenvolvimentista.

Na década de 1970, a questão indígena passou a ganhar espaço na cena nacional a partir da atuação de órgãos e organizações de apoio aos indígenas que passaram a questionar as políticas oficiais e práticas indigenistas da Fundação Nacional do Índio (FUNAI), órgão indigenista oficial do país criado na década anterior.

Nos anos de 1980 os povos indígenas organizaram-se politicamente, tanto regional quanto nacionalmente, fortalecendo-se e conquistando espaço na efervescência das mobilizações sociais daquela década. A grande ruptura de paradigmas se deu no bojo do processo de redemocratização do país, com a Constituição de 1988, que reconhece os indígenas como dotados de direitos, como os de cidadania, o de viver em seus territórios originários e de manterem sua organização social, línguas, hábitos e costumes. A chamada Constituição Cidadã garante também a legitimidade dos indígenas e de suas associações em juízo para defesa dos seus direitos. 0 reconhecimento da diferença e da capacidade jurídica rompe com o paradigma assimilacionista que estabelecia a necessidade de tutela, estabelecendo uma nova relação entre o Estado brasileiro e os povos indígenas (GARNELO, 2012; CIMI, 2013b).

Ainda no campo jurídico, a Declaração de Princípios Sobre a Tolerância, de 1995, a Convenção 169 da Organização Internacional do Trabalho (OIT), da qual o Brasil é signatário desde 2002, e a Declaração das Nações Unidas Sobre os Direitos dos Povos Indígenas, de 2007, reforçam os direitos fundamentais dos povos indígenas no plano internacional.

A partir da Constituição de 1988 foram elaboradas outras leis para a garantia de proteção e assistência aos povos indígenas como, por exemplo, as relacionadas a políticas específicas e diferenciadas de saúde e educação escolar.

Desde 1999 os povos indígenas contam com um Subsistema de Atenção à Saúde Indígena (SASI-SUS). Criado com o objetivo de garantir uma assistência à saúde de qualidade de acordo com os princípios do Sistema Único de Saúde (SUS). O SASISUS considera as especificidades socioculturais, epidemiológicas e demográficas deste grupo populacional (BRASIL, 1999). Apesar destes avanços, a saúde indígena 
ainda vive uma realidade difícil, as condições sanitárias continuam precárias e a assistência à saúde está encontra-se ainda bem distante do almejado (CARDOSO, 2015).

Os povos indígenas conquistaram também o direito à educação escolar específica, diferenciada, intercultural e bilíngue, hoje de competência do Ministério da Educação cuja execução compete aos estados e municípios (BRASIL, 1996). A educação formal, antes utilizada como instrumento de dominação e assimilação passou a ser instrumento de recuperação das memórias, de proteção cultural e de conhecimento do mundo externo colaborando na formação política e no fortalecimento da capacidade de diálogo e interlocução crítica com a nossa sociedade (GOMES, 2012). Contudo, as especificidades das escolas ainda não são satisfatoriamente acolhidas na estrutura dos sistemas de ensino e nos projetos dos dirigentes estaduais e municipais, comprometendo a execução da proposta (BANIWA, 2013).

A importância da terra para os povos indígenas vem da sua condição de elemento indispensável na garantia da reprodução dos modos de viver. Uma vez comprometida, há consequências diretas sobre a reprodução biológica e sociocultural, e ainda sobre as condições de vida e saúde (SANTOS et al., 2007). A demarcação de terras esteve constantemente na contramão dos projetos nacionais de crescimento e desenvolvimento econômico permanecendo até a atualidade como uma das principais causas dos conflitos entre indígenas e as sociedades do entorno de seus territórios.

O Estado, através da Constituição e dos acordos internacionais, reconheceu os indígenas como cidadãos dotados de direitos pertencentes à sociedade brasileira. No entanto, este reconhecimento não encontra eco social e político em toda a sociedade brasileira. O aparato jurídico e político deflagrado a partir da Constituição e a capacidade de resistência dos povos indígenas não foram ainda suficientes para romper com a contínua situação de invisibilidade social a que estão submetidos. Por vezes, essa invisibilidade é quebrada pela divulgação de eventos conflituosos, denúncias sobre a precariedade das condições sociais, de vida e de saúde ou pela divulgação dos rituais e práticas tradicionais indígenas, apresentados como excêntricos, exóticos, mágicos ou primitivos. A luta pela terra é, em geral, o principal motivador dos conflitos que, capturados pelos grandes veículos nacionais de 
comunicação, tendem a reforçar o estereótipo de selvageria e brutalidade dos indígenas, desqualificando a legitimidade de sua luta. Por outro lado, o distanciamento do estereótipo, pode também constituir uma forma de desqualificação. Uma vez não reconhecidos em sua identidade, erroneamente classificados como aculturados, os indígenas perdem a legitimidade de suas reivindicações.

A situação é de uma arena de conflitos em que a violência é uma constante. Segundo os relatórios publicados pelo Conselho Indigenista Missionário (CIMI, 2013a, 2014, 2015), casos de violência como como assassinatos, atropelamentos, espancamentos e ameaças de morte, cresceram de maneira preocupante. $O$ aumento de suicídios entre grupos indígenas também é preocupante. Além dos conflitos relacionados à terra, os relatórios citam ainda como fontes de violência, a exploração de recursos minerais, a degradação ambiental e os danos ao patrimônio.

Para Arruda (2012) a exploração dos povos indígenas é uma constante, travestida nos dias de hoje por um discurso oficial de respeito às diferenças, legitimado juridicamente, mas, que ainda não conseguiu garantir uma prática social coerente.

Os povos indígenas não foram assimilados ou integrados. Ao contrário, continuam crescendo, recriando e ressignificando suas práticas culturais. Não deixaram de ser índios e continuam buscando seu lugar na sociedade brasileira. Dão mostras de inegável capacidade política e de resistência ao paradigma ocidental, à hegemonia do capitalismo e aos planos e projetos de desenvolvimento do país. Segundo o IBGE (2010), há no Brasil 896.917 indígenas, representantes de 305 povos e falantes de 274 línguas, constituindo uma parcela de 0,44 \% da população brasileira. Este número é muito inferior aos cinco milhões estimados em 1500. O IBGE aponta ainda que a maior parte $(61,5 \%)$ reside dentro das terras indígenas distribuídas por todo o território nacional, com maior concentração nas regiões norte e centro oeste. O restante reside nas cidades. De acordo com a FUNAI [s.d.], há ainda 107 referências de índios isolados em toda Amazônia Legal e 19 terras indígenas com índios de recente contato. Alguns povos, considerados extintos até então, têm reaparecido no cenário nacional, como é o caso de etnias ressurgentes, principalmente nas regiões norte e nordeste. 
Falar de povos indígenas no Brasil, hoje, implica em reconhecer sua grande diversidade sociocultural, sua dispersão geográfica, muitas vezes em regiões de difícil acesso, e uma variedade de experiências de contato com a nossa sociedade. É necessário considerar ainda a extensão territorial e as condições de sustentabilidade ambiental das terras Indígenas, assim como os impactos socioambientais que essas populações enfrentam com projetos econômicos desenvolvidos no entorno e no interior de seus territórios.

\section{5- A ATENÇÃO À SAÚDE DOS POVOS INDÍGENAS NO BRASIL E O DESAFIO DA ATENÇÃO DIFERENCIADA}

Do ponto de vista teórico, a Política Nacional de Saúde Indígena e a concepção do SASISUS é inovadora e pioneira nas Américas. Mas, infelizmente, até o presente momento, a atenção à saúde indígena tem encontrado dificuldades em mudar as suas práticas.

Douglas Rodrigues

A atenção à saúde dos povos indígenas no Brasil está atualmente ancorada em uma política pública afirmativa, que salienta o respeito às especificidades socioculturais e práticas tradicionais destes povos, caracterizando-se como um subsistema de saúde dentro do SUS e seguindo seus princípios.

A criação do Subsistema de Atenção à Saúde Indígena (SASI-SUS) em 1999 teve suas bases no movimento político indígena apoiado por indigenistas e articulado com o movimento da reforma sanitária na década de 1980. A principal reivindicação dos indígenas era uma atenção à saúde diferenciada e de qualidade pautada no reconhecimento e respeito às suas especificidades socioculturais. A I Conferência Nacional de Proteção à Saúde do Índio ocorreu em 1986, concomitante à VIII Conferência Nacional de Saúde, e recomendou que a atenção à saúde fosse coordenada diretamente pelo Ministério da Saúde e operacionalizada por meio de um subsistema integrado ao SUS. Até então, a assistência à saúde dos indígenas esteve caracterizada por ações descontínuas, assistemáticas e de foco emergencial, além de ter sido pouco priorizada dentro das políticas indigenistas oficiais que surgiram a partir de 1910, com a criação do Serviço de Proteção ao Índio (SPI) (FUNASA, 2002). 
Vinculado ao Ministério da Agricultura e com inspirações positivistas, o SPI tinha como missão proteger e integrar os indígenas à sociedade nacional. No que diz respeito à saúde, prevaleceram ações emergenciais esporádicas e assistemáticas, inseridas no contexto de pacificação e de integração (FUNASA, 2002; CIMI, 2013b; ISA, [s.d.b]).

A primeira tentativa mais sistematizada no campo da saúde voltada aos povos indígenas foram as ações do Serviço de Unidades Sanitárias Aéreas (SUSA) criado em 1956. Este serviço foi instituído pelo recém-criado Ministério da Saúde, estava vinculado ao Serviço Nacional de Tuberculose e tinha a sua frente o médico sanitarista Noel Nutels. O SUSA executava ações de vacinação, atendimento odontológico e controle de doenças infecciosas endêmicas, com ênfase para a tuberculose. As ações estavam direcionadas à população rural e indígena. Apesar dos esforços e do impacto positivo de suas ações, principalmente nas situações de epidemia, o SUSA não conseguiu modificar o quadro sanitário dos indígenas (COSTA, 1987; CARDOSO et al., 2007).

O SPI não impediu o avanço sobre as terras e os ataques contra os indígenas suscitados pelo projeto de expansão nacional. Sua ineficiência foi explicitada em meio a uma crise institucional marcada por denúncias de corrupção, genocídio e escravização. Em substituição ao SPI, a Fundação Nacional do Índio (FUNAI) foi criada em 1967. Vinculada ao Ministério da Justiça, a fundação nasceu com o objetivo de solucionar definitivamente a questão indígena no país, por meio de um projeto de assimilação e integração dos indígenas à sociedade nacional. A criação da FUNAI estava em sintonia com o projeto de expansão das fronteiras agrícolas para o interior do país, em especial na região amazônica (ISA, [s.d.a]).

Foi a partir da criação da FUNAI que os primeiros profissionais de saúde passaram a se fixar e desenvolver ações dentro das áreas indígenas. Eram, em sua maioria, profissionais de enfermagem com pouca qualificação para o trabalho, sem formação específica e atuando em condições precárias ${ }^{4}$.

\footnotetext{
${ }^{4}$ Tal situação era reflexo do que ocorria no cenário nacional, com o expressivo aumento da força de trabalho na saúde decorrente da reformulação no setor, ocorrida a partir da segunda metade da década de 60 e que teve a expansão da cobertura assistencial como uma de suas características. $\mathrm{O}$ aumento da força de trabalho privilegiou os profissionais de nível técnico e não foi acompanhado de qualificação necessária. (MÉDICI, 1985; 1986).
} 
A supervisão desses profissionais era realizada pelas Equipes Volantes de Saúde (EVS), serviço criado com o objetivo de prestar assistência médica, odontológica, e ações de saúde e de assistência social dentro dos territórios indígenas. O modelo de atenção campanhista das EVS, clássico do sanitarismo, caracterizou-se por uma atenção à saúde curativa e medicalizante, carente de planejamento, infraestrutura e articulação como os demais serviços de atenção. Nas décadas de 1980 e 1990, a FUNAI enfrentou uma crise política e a atenção à saúde tornou-se cada vez mais desorganizada. Com o tempo, os profissionais foram se afastando do trabalho em $a^{2} a^{5}$. No início da década de 1980, a presença de profissionais - em sua maioria atendentes e técnicos de enfermagem - estava restrita a poucas áreas indígenas (CONFALONIERI,1989; VERANI, 1999; CARDOSO et al., 2007; RODRIGUES, 2014; CARDOSO, 2015).

A responsabilidade pela atenção à saúde dos indígenas permaneceu na FUNAl até 1991, quando foi transferida para o Ministério da Saúde. Para realizar a gestão do trabalho, foi criada a Fundação Nacional de Saúde (FUNASA), órgão que ficou responsável pela saúde indígena a partir de então. A falta de experiência com as políticas e ações de saúde e a estrutura burocrática impediram que a recém-criada FUNASA conseguisse atender as demandas da saúde indígena em sua totalidade justificando, a partir daí, um convênio com a FUNAI, no qual a responsabilidade pela gestão da saúde passou a ser compartilhada entre os dois órgãos. A FUNASA só assumiu a totalidade da responsabilidade pela saúde indígena em 1999, com o estabelecimento do Subsistema de Atenção à Saúde Indígena (SASI-SUS) (GARNELO, 2012; RODRIGUES e MENDONÇA, 2015).

A criação do SASI-SUS representou uma conquista de direitos pelo movimento indígena. Até então, "[...] as iniciativas de atenção à saúde indígena geralmente ignoravam os sistemas de representações, valores e práticas relativas ao adoecer e buscar tratamento dos povos indígenas, bem como seus próprios especialistas" (FUNASA, 2002, p.8).

\footnotetext{
5 As expressões "em campo" e "de campo" derivam da expressão "trabalho de campo", utilizada pela antropologia para se referir ao levantamento de dados no contexto do estudo, utilizando-se metodologias adequadas. Neste estudo, as expressões "em campo" e "em área" serão utilizadas para se referir ao espaço geográfico do interior das áreas indígenas.
} 
Os principais marcos históricos e legais deste processo são: as I e II Conferências Nacionais de Saúde Indígena (CNSI), espaços legítimos de discussão nos quais foram propostas as bases para o Subsistema; a lei 9836/99 (Lei Arouca) que estabelece o Subsistema de Atenção Saúde Indígena no âmbito do SUS e a Política Nacional de Atenção à Saúde dos Povos Indígenas (PNASPI portaria 254 de 2002 MS), que integra a Política Nacional de Saúde e orienta a assistência à saúde dos povos indígenas em todo o país.

O Subsistema deve garantir uma atenção à saúde de acordo com os princípios doutrinários do SUS. Além disso, a assistência deve ser pautada pelo respeito às práticas e costumes tradicionais e deve considerar todas as especificidades relacionadas aos povos indígenas estabelecendo uma diferenciação na qualidade dos serviços por meio do princípio da atenção diferenciada (FUNASA, 2002; LANGDON e DIEHL, 2007; FERREIRA, 2013).

A organização do Subsistema se dá a partir de 34 Distritos Sanitários Especiais Indígenas (DSEI), distribuídos em todo o território nacional (Mapa 1). Os DSEI são unidades gestoras de um espaço territorial, definido a partir de critérios geográficos, populacionais e etnoculturais, dotadas de autonomia política e financeira e responsáveis pelas atividades de promoção, prevenção e controle de agravos com base no perfil epidemiológico e especificidades culturais locais (FUNASA, 2002). Grande parte dos DSEI estão localizados na região amazônica, onde se concentra a maior parte das terras indígenas brasileiras. Geograficamente, os territórios dos DSEI não obedecem à organização político-administrativa do país, com limites que tangenciam mais de um município ou estado. Há também situações como a do povo Yanomami, cuja terra indígena se estende até a Venezuela, e a dos Guarani Kaiowá da região sul, cujo território originário se localiza na região da tríplice fronteira entre Brasil, Paraguai e Argentina. 
Mapa 1 - Distribuição dos 34 Distritos Sanitários Especiais Indígenas.

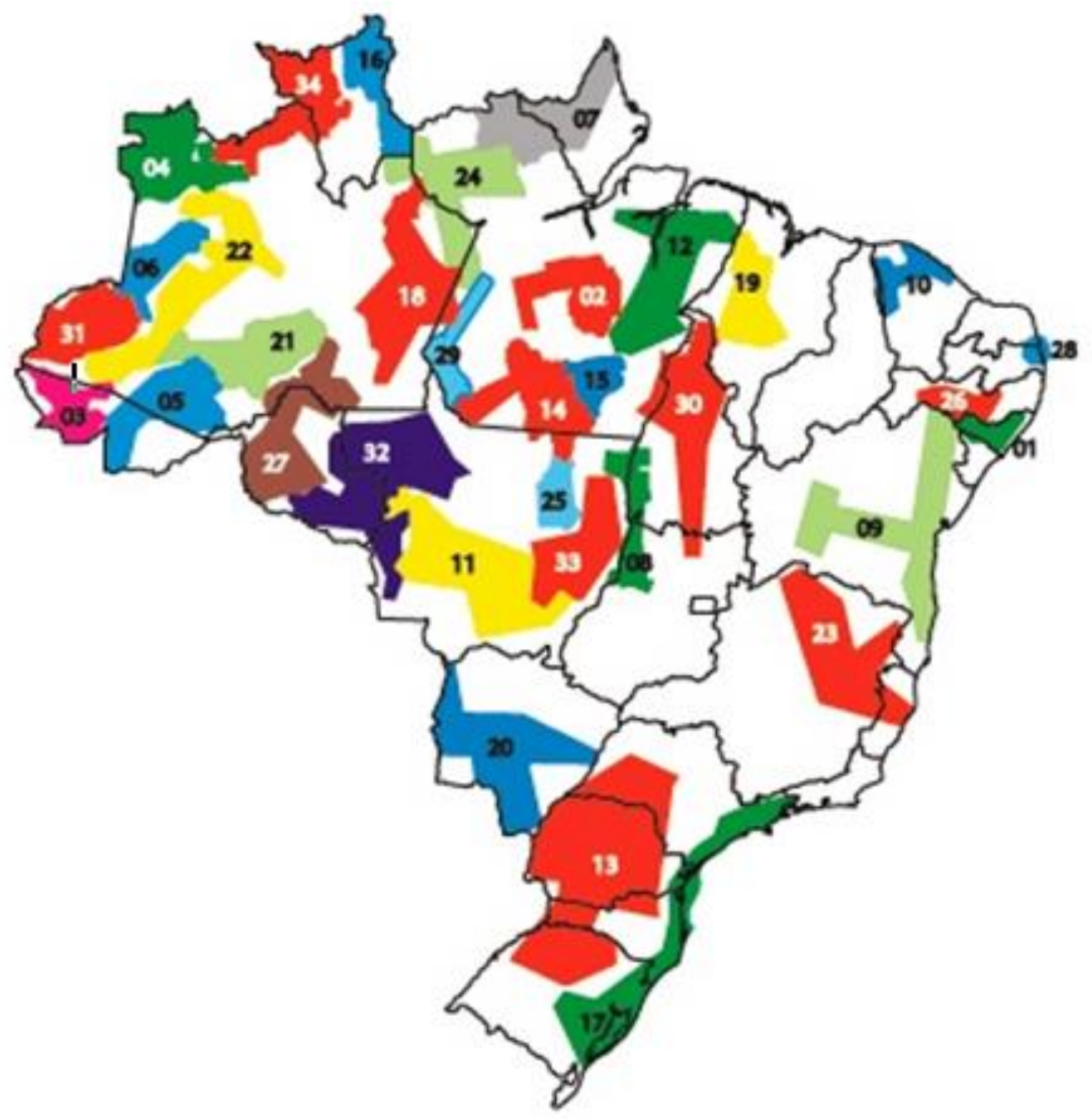

\begin{tabular}{|c|c|}
\hline 01-Alagoss e Sergipe - AL/SE & 18-Mangus-AM \\
\hline 02 - Altamira - PA & 19-Maranhåo - MA \\
\hline 03-Alto Rio Juruǵ - AC & 20-Mato Grosso do Sul - MS \\
\hline 04-Alto Rio Negro - AM & 21-Médio Rio Purus - AM \\
\hline 05- Alto Rio Purus - ACIAMRO & 22-Médio Rio Solimőes e afluentes - AM \\
\hline 06- Alto Rio Solimōes - AM & 23- Minas Gerais e Espírito Santo - MG/ES \\
\hline 07-Amspá e Norte do Pará - AM PA & 24-Parintis - AMVPA \\
\hline 08- Araguaia - GO/MT/TO & 25- Parque Indigena do Xingu -MT \\
\hline 09-Bghig - BA & 26-Pernambuco-PE \\
\hline 10-Ceará-CE & 27-Porto velho - AMMT/RO \\
\hline 11- Cuisbá - MT & 28-Potiguara - PB \\
\hline 12- Guamá Tocantins - MA/PA & 29-Rio Tapajós-PA \\
\hline 13-Interior Sul - PR/RS/SCISP & 30-Tocantins - TO \\
\hline 14- Caispó do Mato Grosso - MT/PA & 31- Vale do rio Javari - AM \\
\hline 15- Caiapó do Pará - PA & 32-Vilhens - MT/RO \\
\hline 16- Leste de Roraima - RR & 33- Xavante-MT \\
\hline 17- LitorglSul - PR/RJ/RS/SC/SP & 34- lanomámi- AM/RR \\
\hline
\end{tabular}

Fonte: FUNASA, 2003. 
Dentro do território são realizadas ações de atenção básica a saúde por Equipes Multidisciplinares de Saúde Indígenas (EMSI), compostas por profissionais indígenas e não indígenas. A composição das EMSI deve ser orientada pelas particularidades locais, como o perfil epidemiológico, a dispersão territorial e a população de cada DSEI. O modelo de atenção proposto é o da vigilância em saúde. Cabem ainda aos DSEI, a interlocução e a articulação com os serviços locais e regionais da rede SUS, para o atendimento das demandas de maior complexidade, garantindo a integralidade da atenção à saúde. Também faz parte da estrutura dos DSEI as Casas de Saúde do Índio (CASAI), que tem por finalidade garantir a remoção e o acolhimento dos indígenas que forem referenciados para os serviços de atenção de média e alta complexidade nas áreas urbanas (FUNASA, 2002).

O planejamento das ações ocorre na elaboração dos Planos Distritais de Saúde Indígena a cada quatro anos. A participação dos indígenas na gestão se faz através do controle social. No âmbito nacional, há a Comissão Intersetorial de Saúde Indígena (CISI), um comitê que tem função consultiva e assessora do Conselho Nacional de Saúde. No plano local, o controle está organizado por meio dos conselhos local e distrital de saúde indígena. O Conselho Distrital de Saúde Indígena (CONDISI) tem caráter deliberativo e, entre outras funções, acompanha o planejamento, a execução e a avaliação das ações de saúde.

Desde sua criação, o SASI-SUS vem se consolidando. A gestão da FUNASA foi marcada pela dificuldade operacional e pela compra de serviços. A FUNASA terceirizou a assistência dentro das aldeias, por meio da celebração de convênios com diversas instituições e serviços com distintas formas de atuação e interesses (CARDOSO et al., 2007; GARNELO, 2012; FERREIRA et al., 2013).

Em 2010, dando início a uma nova fase da Política Nacional de Saúde Indígena, a gestão passou a ser responsabilidade da então recém-criada Secretaria Especial de Saúde Indígena (SESAI), diretamente ligada ao Ministério da Saúde (BRASIL, 2010). Tratava-se de uma antiga reivindicação dos povos indígenas expressa na $1^{\text {a }}$ CNSI. Com a criação da SESAI, os DSEI passaram a gozar de autonomia política e financeira, atuando, a partir daí, como unidades gestoras. Isso provocou uma ruptura 
com o modelo de gestão altamente burocrático desenvolvido até então pela FUNASA (BRASIL, 2010; CIMI, 2013b).

Dentre as ações mais imediatas, ocorreu um expressivo aumento da força de trabalho e uma melhora nas relações trabalhistas. A contratação de profissionais ainda continua terceirizada. Em 2012, havia 12.184 profissionais atuando na saúde indígena, representando um aumento de $43 \%$ da força de trabalho desde a criação da SESAI ${ }^{6}$. Metade desta força de trabalho é composta por profissionais indígenas e a outra metade formada por profissionais de várias áreas da saúde ${ }^{7}$. Dados mais atualizados sobre a força de trabalho não estão disponíveis no site oficial da SESAI, e as solicitações de informações a esse respeito não foram atendidas.

Avaliada pelo seu conteúdo textual, a PNASPI é afirmativa de direitos e propositora de uma atenção à saúde diferenciada. O respeito às concepções e valores indígenas sobre o processo saúde doença é o princípio que norteia um conjunto de diretrizes que se relacionam de forma articulada e complementar.

O propósito desta política é garantir aos povos indígenas o acesso à atenção integral à saúde, de acordo com os princípios e diretrizes do Sistema Único de Saúde, contemplando a diversidade social, cultural, geográfica, histórica e política, de modo a favorecer a superação dos fatores que tornam essa população mais vulnerável aos agravos à saúde de maior magnitude e transcendência entre os brasileiros, reconhecendo a eficácia de sua medicina e o direito desses povos à sua cultura (FUNASA, 2002, p.13).

Apesar de fundamentais, as diretrizes por si só não são suficientes para garantir a efetivação dos DSEI como um modelo assistencial. Na prática, os dispositivos oferecidos para a sua efetivação são ora insuficientes, ora conflitantes e até mesmo contraditórios aos seus propósitos.

\footnotetext{
6 Notícia veiculada no site do Ministério da Saúde, disponível em: $<$ http://www.blog.saude.gov.br/servicos/29703-forca-de-trabalho-em-saude-indigenaaumenta-43>. Acesso em: 15 nov. 2015.

${ }^{7}$ Apresentação do Departamento de Atenção à Saúde da SESAI na Oficina Nacional de Proteção à Saúde e Promoção de Direitos de Índios Isolados e de Recente Contato, Brasília, 2013.
} 
O processo de criação e consolidação dos DSEI se deu de forma bastante heterogênea nas várias regiões, o que fez com que cada uma dessas unidades se estabelecesse de forma bastante peculiar, a partir das especificidades locais. Apesar disso, os DSEI compartilham de dificuldades semelhantes, que apontam para os desafios de sua efetivação como modelo assistencial. Ao contrário, tem se firmado como um espaço geográfico, populacional e administrativo de organização de ações e serviços, reduzindo-se assim a um modelo organizacional. De forma geral, não há uma adequabilidade das práticas de saúde, que permanecem pautadas pelo paradigma médico curativo e ainda muito distantes dos propósitos do modelo de vigilância da saúde. Observa-se também falta a de infraestrutura para o trabalho, a alta rotatividade e o despreparo profissional, a articulação insuficiente com os serviços de referência do SUS e a carência de dados epidemiológicos e demográficos fidedignos (IDS-SSL-CEBRAP, 2009; FERREIRA et al., 2013; CARDOSO, 2015).

A assistência à saúde de forma contínua se constituiu como um desafio antigo que passou a ser enfrentado com instituição das Equipes Multidisciplinares de Saúde Indígena (EMSI). Contudo, o provimento e a fixação de profissionais em área persistem como uma dificuldade, principalmente quando se trata de profissional médico.

Em 2015, pela primeira vez na história, todos os 34 DSEl passaram a contar com médico na composição de suas equipes, uma das contribuições do Programa Mais Médicos para o Brasil (BRASIL, 2015a).

A burocratização e a institucionalização características dos espaços de controle social, não correspondem aos modelos tradicionais de organização social e de representatividade dos indígenas. Isso tem comprometido a participação efetiva deles na gestão da saúde (LANGDON e DIEHL, 2007; RODRIGUES e MENDONÇA, 2015).

Para Coimbra Jr e Santos $(2000,2003)$ apesar da carência de dados demográficos e epidemiológicos fidedignos sobre os povos indígenas no Brasil, "[...] restam poucas dúvidas que as condições de saúde dos povos indígenas são precárias, colocandoos em uma posição de desvantagem em relação a outros segmentos da sociedade nacional" (COIMBRA JR e SANTOS, 2000, p.129). 
Indicadores de saúde importantes como, por exemplo, coeficiente de mortalidade geral e a mortalidade infantil, apresentam índices muito superiores aos da população geral e estão muito acima do considerado aceitável pela Organização Mundial de Saúde (OMS). As doenças infecciosas, parasitárias e do aparelho respiratório constituem agravos muito frequentes e estão relacionadas especialmente com a morte entre crianças. A tuberculose, um dos fatores responsáveis pela depopulação no passado, atualmente é uma das principais endemias que acometem os povos indígenas, especialmente crianças. A incidência e a morte por tuberculose é também mais alta entre os indígenas, com relação aos demais segmentos da população. A malária sempre foi expressiva no perfil epidemiológico e ainda é um problema importante em algumas regiões (COIMBRA JR et al., 2007; FUNASA, 2010; BRASIL, 2015b). Entre 2008 e 2009, foi realizado o I Inquérito Nacional de Saúde e Nutrição dos Povos Indígenas, envolvendo crianças e mulheres entre 14 e 49 anos, de várias regiões do país. Nele foram identificados problemas importantes, como a precariedade do saneamento básico nas aldeias e altas prevalências de desnutrição, anemia, diarreia e doenças respiratórias agudas, entre crianças menores de cinco anos. Entre as mulheres foi identificada alta emergência de obesidade, hipertensão arterial e diabetes (COIMBRA JR., 2014).

Somado aos velhos problemas de saúde já muito conhecidos, e ainda não superados, como a alta prevalência de doenças infectocontagiosas e parasitárias, observa-se o impacto de novos agravos à saúde ainda pouco estudados nesta população e frequentemente associados às mudanças do modo de viver, intensificação do contato com a sociedade envolvente e mudanças ambientais (SANTOS e COIMBRA JR., 2003; GIMENO et al., 2007). A emergência de doenças crônicas não transmissíveis, o consumo de álcool, a violência e o suicídio tornaramse atualmente problemas socialmente significativos reveladores da vulnerabilidade social e de saúde em que vivem muitos grupos indígenas.

O princípio da atenção diferenciada é o elemento de destaque do Subsistema de Atenção à Saúde Indígena (SASI-SUS). A proposta de uma atenção diferenciada expressa, na Política Nacional Saúde Povos Indígenas está diretamente relacionada com o princípio da equidade, e reforça o reconhecimento da especificidade sociocultural dos povos indígenas e suas implicações para o campo da saúde. Entre as diretrizes da política, a formação profissional e a articulação com os sistemas 
tradicionais indígenas se destacam como instrumentos para efetivação da proposta. Contudo, nos documentos oficiais não há uma descrição clara do que caracterizaria essa prática. O termo "atenção diferenciada" carece de um entendimento mais amplo, e isso tem levado ao uso simplificado, reducionista e incorreto da expressão, em geral associada ao acesso a ações e serviços de saúde, que deixam de ser entendidos como um direito e passam a ser interpretados, equivocadamente, como um privilégio (LANGDON e DIEHL, 2007; FERREIRA, 2013, 2015; RODRIGUES et al., 2015).

Em estudo realizado sobre as práticas sanitárias no DSEI Alto Rio Negro, Rocha (2007) identificou um entendimento equivocado, por parte dos profissionais das equipes de campo, sobre o que seria atenção diferenciada e promoção à saúde. Nas colocações dos participantes da pesquisa, tais práticas são exemplificadas pela presença das equipes dentro das áreas indígenas e realização de ações como os atendimentos domiciliares.

Da mesma forma, a recomendação sobre a articulação com as práticas tradicionais de cura não esclarece os caminhos pelos quais esta articulação poder ser efetivada e sob qual perspectiva ela é engendrada (FERREIRA, 2015).

\section{6 - O DSEI XINGU}

1.6.1 - Histórico da Assistência à Saúde no Parque Indígena do Xingu

Criado em 1961, o Parque Indígena do Xingu foi a primeira grande terra Indígena reconhecida no Brasil, com a finalidade de preservar a terra, os indígenas que ali habitavam ou que haviam sido transferidos para lá porque estavam ameaçados pelo avanço da colonização. Atualmente possui uma extensão de 2.642 .004 hectares, bastante inferior ao projeto inicial, e abriga 6.475 indígenas $^{8}$ pertencentes a 16

${ }^{8}$ Informação extraída do censo populacional de dezembro de 2016 disponibilizado pelo DSEI Xingu em janeiro de 2017. 
etnias, falantes de línguas dos troncos Jê e Tupi e das famílias linguísticas Karib e Aruak, além da língua Trumai, que é uma língua isolada (ISA, [s.d.c]).

A assistência à saúde aos indígenas teve início antes da criação do PIX, por meio de atividades desenvolvidas pelo sanitarista Noel Nutels, criador do Serviço de Unidades Sanitárias Aéreas (SUSA) em 1956, e com colaboração dos médicos da Força Aérea Brasileira. Como visto anteriormente, Tais atividades tinham caráter campanhista e estavam voltadas a populações de área de difícil acesso.

A Escola Paulista de Medicina (EPM), atualmente denominada Universidade Federal de São Paulo (UNIFESP) iniciou suas atividades no PIX em 1965 por meio de um acordo de colaboração mútua entre a direção do Parque e o Departamento de Medicina Preventiva da EPM. Esta parceria tinha como objetivo a assistência médica aos indígenas do PIX no contexto do cumprimento de uma das atribuições do Parque, que consistia na garantida da sobrevivência dos povos que ali habitavam. Nesse contexto, foi criado no mesmo ano o Projeto Xingu, um projeto de extensão universitária também vinculado ao Departamento de Medicina Preventiva da EPM. Naquele momento, o trabalho se caracterizou por viagens periódicas ao PIX para realização de ações de saúde, desenvolvidas por uma equipe multidisciplinar, com a participação de alunos e residentes de medicina e enfermagem. Assistência, ensino e pesquisa formam definidos como os eixos norteadores do trabalho, que também priorizou a valorização e a interlocução com as práticas tradicionais de saúde e o protagonismo dos indígenas, configurando uma proposta inovadora e bem diferente da realidade assistencial de outras áreas indígenas do país. Dentre as ações desenvolvidas, a imunização se destacou por sua colaboração decisiva na recuperação e aumento da população, por meio do controle de epidemias importantes, como a do sarampo (COSTA, 1987; BARUZZI, 2005, 2007; VILLAS BÔAS, 2005; ISA, 2011).

Esta colaboração se estende até os dias de hoje. Ao longo de mais de 50 anos, o trabalho foi sofrendo modificações, acompanhando as mudanças ocorridas tanto no PIX quanto na configuração da assistência à saúde dos indígenas no Brasil. Durante este período, foram realizados diversos arranjos com a gestão responsável pela assistência à saúde no PIX. Durante a gestão da FUNAI (criada em 1967), a parceria foi estabelecida por meio de um convênio no qual a EPM manteve o papel 
de colaboradora na assistência à saúde, cabendo ao órgão gestor garantir toda a infraestrutura e recursos necessários dentro da área indígena. Em 1999, a gestão passou a ser realizada pela FUNASA que manteve o convênio com a EPM, agora Universidade Federal de São Paulo (UNIFESP), acrescentando, porém, outras características para além da prestação da assistência à saúde. Neste convênio, coube à UNIFESP toda a gestão da assistência no DSEI Xingu, incluindo entre suas atribuições: encargos administrativos, controle de verbas, compra de insumos, controle dos meios de transporte, contratação de pessoal e formação de recursos humanos (BARUZZI, 2007).

Um dos frutos desse trabalho é a experiência acumulada pela UNIFESP na formação de profissionais que atuam na saúde indígena. No processo de formação de indígenas e não indígenas, o cotidiano do trabalho em saúde foi explorado como locus fundamental do aprendizado, considerando o princípio educativo do trabalho. A metodologia problematizadora, a pedagogia histórico-crítica, a aprendizagem reflexiva, o diálogo intercultural e a valorização das práticas tradicionais indígenas também compõem os eixos do processo de formação. Outra característica importante desta experiência, é a interlocução com a educação escolar indígena, que se dá por meio da participação ativa dos professores indígenas nas etapas do curso de formação de profissionais indígenas e na produção de livros didáticos junto com os alunos. A formação de Agentes Indígenas de Saúde, de auxiliares de enfermagem indígenas e a preparação de profissionais técnicos para atuação em campo são produtos desta experiência muito particular desenvolvida com ares artesanais (MENDONÇA, 2005; OLIVEIRA, 2005b).

Para os profissionais não indígenas era destinada uma atenção particular, que se iniciava no processo seletivo criterioso, passando por uma cuidadosa inserção no trabalho e se estendia por meio de um acompanhamento sistemático durante 0 período em que estes profissionais atuavam em campo. Esse acompanhamento consistia em fornecimento de aporte teórico de conteúdos diversos de antropologia, política, história e sobre os povos que residem no PIX, reuniões técnicas e oferta de cursos e capacitações técnicas (RECH, 2008).

Com a criação da SESAI, em 2010, toda a gestão passou a ser realizada pelo DSEI. A partir daí, as atividades de seleção e inserção de profissionais no trabalho dentro 
de área foram realizadas pela UNIFESP em caráter colaborativo, por solicitação do DSEI Xingu, até o ano de 2012.

Atualmente, atendendo à vontade manifesta dos indígenas, por meio de um termo de colaboração, a UNIFESP, através do Projeto Xingu, realiza atividades de apoio, assistência e gestão, ancoradas ainda no tripé assistência, ensino e pesquisa.

\subsection{2 - Estrutura e Organização do Serviço no DSEI Xingu}

Para organização do trabalho, a área geográfica do DSEI é dividida em quatro regiões de saúde, os polos base: Leonardo, Pavuru, Wawi e Diauarum. A cada um dos polos base corresponde um território de abrangência, no qual reside uma população distribuída em aldeias (Tabela 1).

Tabela 1- Distribuição da população da abrangência do DSEl* Xingu, dezembro de 2016.

\begin{tabular}{lcc}
\multicolumn{1}{c}{ Polo Base } & $\mathbf{N}^{\circ}$ de aldeias & População \\
\hline Leonardo & 37 & 3.246 \\
Pavuru & 14 & 911 \\
Wawi & 11 & 662 \\
Diauarum & 30 & 1.656 \\
\hline Total & $\mathbf{9 2}$ & $\mathbf{6 . 4 5 7}$ \\
\hline
\end{tabular}

Fonte: Censo populacional DSEI Xingu, dezembro de 2016.

*Distrito Sanitário Especial Indígena

Nas aldeias, a atenção básica é realizada por profissionais indígenas e a estrutura para o serviço varia bastante. É possível encontrar tanto aldeias com pequenas Unidades Básicas de Saúde (UBS) equipadas com materiais e equipamentos, quanto aldeias sem nenhuma estrutura específica para o trabalho. Nestas, os atendimentos e as atividades de saúde são realizados, em geral, em domicílio ou nas escolas. Em quase todas as aldeias há a atuação de profissionais de saúde indígenas. Em algumas, há também técnicos de enfermagem e enfermeiros não indígenas atuando continuamente. 
Os Polos Base constituem a primeira referência para o atendimento de demandas que não são resolvidas nas aldeias incluindo pequenos procedimentos cirúrgicos. Após avaliação e intervenção pela equipe no Polo Base, as demandas podem ter três desfechos: o paciente retorna para sua aldeia, ou pode permanecer no polo em tratamento, sob o acompanhamento da equipe o tempo que for necessário, ou é referenciado para uma CASAI.

A estrutura física e os recursos disponíveis variam nos quatro polos base. Em cada um deles há uma UBS, geralmente feita de alvenaria, estruturada e equipada para atender as demandas que não são resolvidas nas aldeias.

Nas abrangências dos polos base Leonardo e Diauarum, há também os chamados pontos de apoio. Tratam-se de aldeias maiores onde há presença constante de profissional de saúde não indígena e que, a exemplo dos Polos Base, funcionam como referência para outras aldeias da região. Os pontos de apoio não fazem parte da estrutura oficinal do SASI-SUS (FUNASA, 2002). Contudo, a autonomia administrativa garantida ao DSEI, permitiu que eles fossem criados como uma estratégia frente às dificuldades advindas da grande dispersão geográfica e o grande número de aldeias na abrangência destes dois respectivos Polos Base.

É também nos Polos Base que residem os profissionais não indígenas. As moradias coletivas comumente chamadas de "casa da equipe", variam em estrutura e tamanho e, geralmente, são feitas de madeira e revestidas com palha. Atualmente, é possível encontrar eletrodomésticos, como freezer, geladeira e televisor, que funcionam na dependência do gerador que fornece energia elétrica ao local.

Dentro do PIX o deslocamento se dá por via terrestre e fluvial. O acesso aos municípios do entorno se dá por via terrestre, fluvial e aérea, a depender da localização, necessidade e disponibilidade do meio de transporte.

A radiofonia ainda é a principal forma de comunicação entre os indígenas dentro de área. Para o serviço de saúde, ela ainda é bastante utilizada pelos profissionais, tanto para contato entre as equipes de campo, quanto para a comunicação com as Casas de Saúde Indígena (CASAI) e com o DSEI. Ao longo dos anos vem crescendo a disponibilidade do acesso à internet e também à telefonia fixa. 
Fora da terra indígena, o DSEI conta com uma sede física localizada no município de Canarana, que abriga toda a estrutura administrativa. A sede do DSEI também é o espaço de trabalho dos profissionais que integram o Núcleo de Apoio a Saúde Indígena (NASI), que tem por finalidade dar apoio às equipes de campo, cumprindo um papel semelhante ao Núcleo de Apoio à Saúde da Família (NASF).

Também faz parte da estrutura do DSEI quatro CASAI nomeadas a partir dos municípios onde estão localizadas: Canarana, Sinop, Querência e Gaúcha do Norte. Esta última é a mais recente, em funcionamento desde 2012. 
Mapa 2 - Abrangência do DSEI Xingu, 2016.
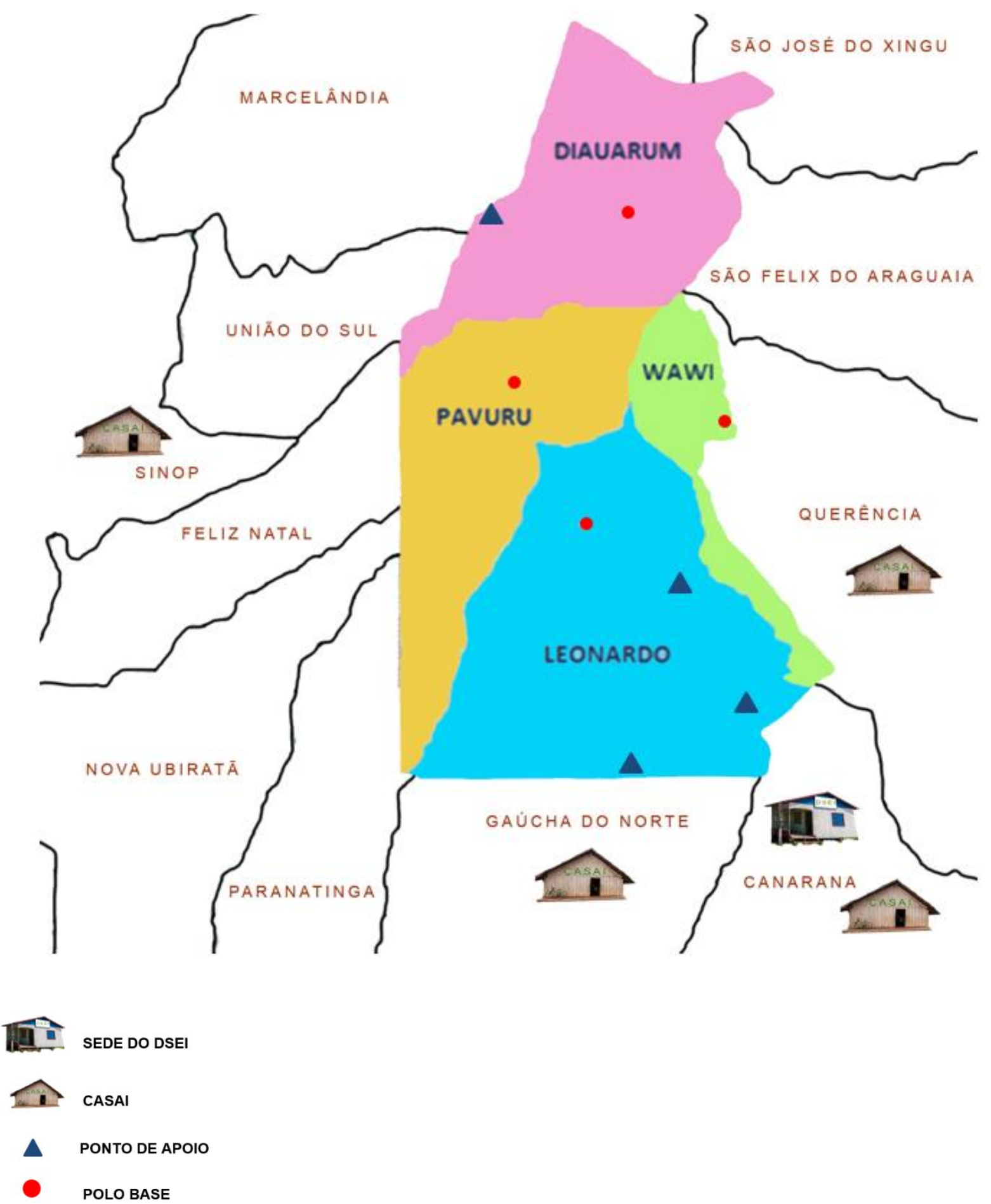

Fonte: Adaptado de ISA, 2011.

*Distrito Sanitário Especial Indígena. 
No momento da realização do estudo, em 2016, no DSEI Xingu, atuavam 264 profissionais de saúde indígenas e não indígenas de diversas áreas. Estes profissionais compunham as EMSI, atuavam nas CASAI e nos demais setores do DSEI (Quadro1). Havia também cinco profissionais médicos intercambistas, vinculados ao Programa Mais Médicos para o Brasil (PMMB) atuando desde 2013. Os enfermeiros representavam aproximadamente 14\% (38) dos profissionais de saúde do DSEI (Mapa 3) ${ }^{9}$.

Quadro 1 - Força de trabalho no DSEl* Xingu, 2016.

\begin{tabular}{|c|c|c|c|}
\hline \multicolumn{2}{|r|}{ Profissionais } & Quantidade & Total \\
\hline \multirow{5}{*}{$\begin{array}{l}\text { Profissionais } \\
\text { indígenas }\end{array}$} & Agente Indígena de Saúde & 77 & \multirow{5}{*}{158} \\
\hline & Agente indígena de saneamento & 61 & \\
\hline & Agente de combate a endemias & 2 & \\
\hline & Auxiliar de saúde bucal & 6 & \\
\hline & Auxiliar de enfermagem indígena & 12 & \\
\hline \multirow{10}{*}{$\begin{array}{l}\text { Profissionais não } \\
\text { indígenas }\end{array}$} & Enfermeiro & 38 & \multirow{10}{*}{111} \\
\hline & Técnico de enfermagem & 48 & \\
\hline & Cirurgião dentista & 5 & \\
\hline & Nutricionista & 3 & \\
\hline & Assistente social & 4 & \\
\hline & Psicólogo & 1 & \\
\hline & Farmacêutico & 3 & \\
\hline & Médicos & 5 & \\
\hline & Engenheiro & 3 & \\
\hline & Apoiador técnico & 1 & \\
\hline
\end{tabular}

Fonte: Associação Paulista para o Desenvolvimento da Medicina (SPDM), janeiro, 2016. *Distrito Sanitário Especial Indígena.

${ }^{9}$ Dados fornecidos pelo DSEI Xingu e pela Associação Paulista para o Desenvolvimetno da Medicina (SPDM), instituição conveniada responsável pela contratação de profissionais, em janeiro de 2016. 
Mapa 3 - Distribuição dos enfermeiros do DSEI* Xingu segundo local de atuação, 2016.
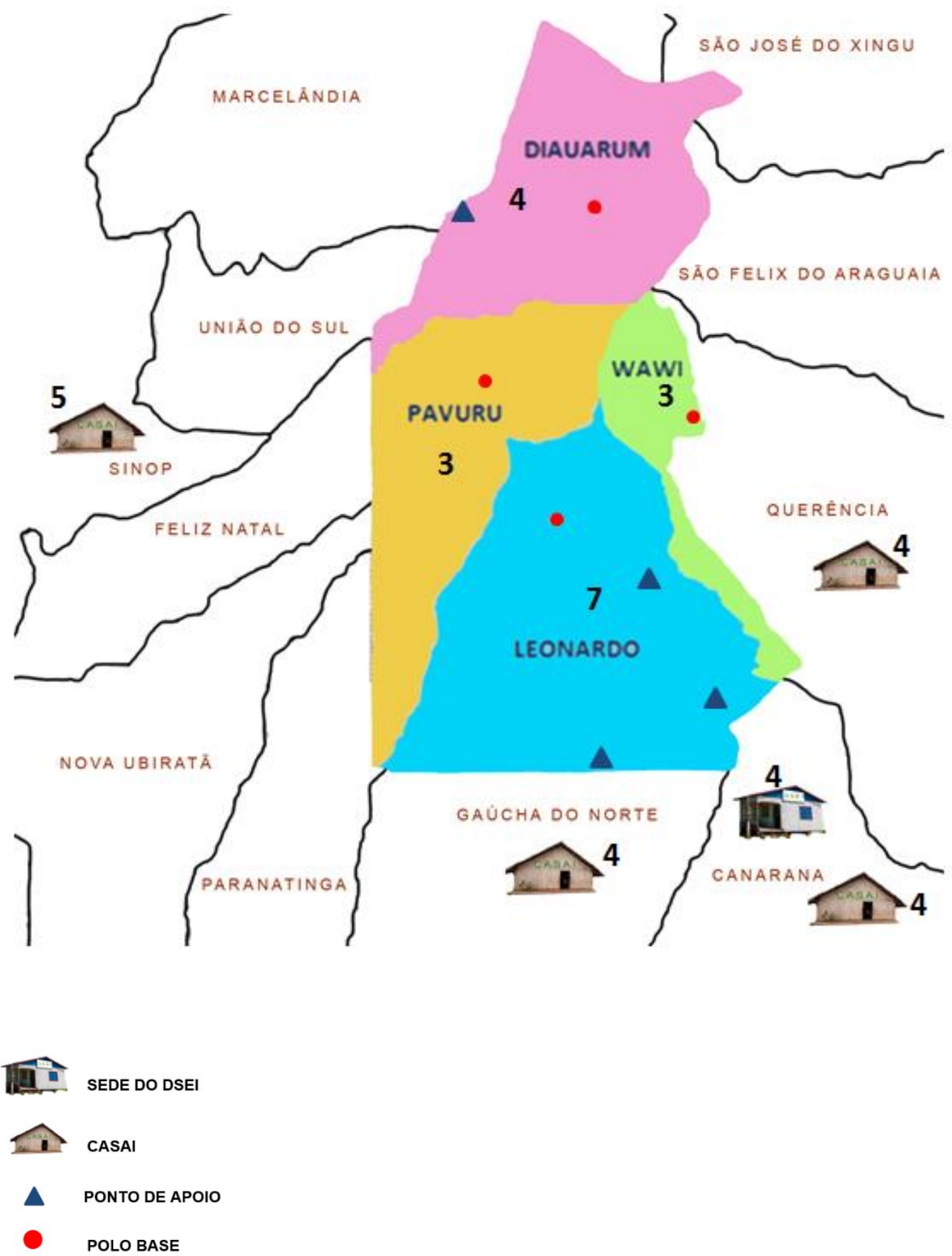

Fonte: Adaptado de ISA, 2011.

*Distrito Sanitário Especial Indígena. 
No DSEI Xingu, com exceção dos médicos, todos os demais profissionais não indígenas que integram as EMSI cumprem uma escala de trabalho na qual permanecem aproximadamente trinta dias no interior da terra indígena, intercalados por quinze dias de descanso fora de área. Por determinação do Programa Mais Médicos para o Brasil, os médicos intercambistas realizam escala de trabalho de quinze dias, seguidos de igual período de folga. Já os profissionais indígenas atuam nas aldeias onde residem e, em situações especiais, precisam desenvolver atividades em outras aldeias ou no Polo Base. Folgas ou ausências dos profissionais indígenas são negociadas diretamente entre a equipe. A presença constante de pelo menos um profissional não indígena em todos os Polos Base é uma cobrança permanente nas comunidades.

Também faz parte da organização do trabalho que os profissionais compareçam ao DSEI antes e depois de entrarem na terra indígena. Essa passagem pela sede do DSEI tem por objetivo discutir questões relacionadas ao trabalho. É comum que alguns profissionais da equipe permaneçam no município de Canarana por alguns dias durante os períodos de folga, no início ou no final da escala de trabalho. Durante este tempo, eles permanecem em moradias coletivas, compartilhadas com outros profissionais.

\subsection{3 - O Trabalho Dentro da Área Indígena e a Atuação da} Universidade

Em cada DSEI, a estrutura, a organização e a prática do trabalho de saúde são determinadas pelas particularidades locais, guardando uma relação estreita com o histórico da assistência à saúde prestada aos povos indígenas, as instituições envolvidas nesse processo, o histórico de contato com as sociedades envolventes e também com a capacidade gestora.

Dentro dos territórios, as EMSI realizam ações e atividades de atenção básica à saúde. Muitas das atividades do trabalho estão relacionadas a protocolos e programas de saúde aplicados nacionalmente, alguns deles adaptados à realidade 
indígena, como, por exemplo, o calendário vacinal e o programa de controle da tuberculose (IDS-SSL-CEBRAP, 2009).

No Parque Indígena do Xingu muitas características do trabalho desenvolvido pelas EMSI guardam uma relação com a atuação pretérita da UNIFESP neste território. No início da atuação da universidade, em 1965, a população do PIX tinha pouco convívio com a sociedade do entorno, e estando muito vulnerável às doenças com as quais ainda não tinha contato. O trabalho consistia no cadastramento e na avaliação periódica das condições de saúde da população, nos atendimentos emergenciais e na imunização. Com o tempo, a atuação da universidade foi se ampliando rumo à implantação de um Sistema Local de Saúde (SILO). Com base no modelo da Vigilância da Saúde e considerando a rápida modificação do modo de vida que já impactava o perfil epidemiológico local a implantação deste sistema teve por objetivo garantir uma assistência à saúde com qualidade, superando as dificuldades inerentes ao trabalho em área de difícil acesso. Para isso, foram elaboradas atividades e ações específicas para o enfrentamento dos principais agravos de saúde, a atenção à saúde bucal e um programa de imunização. Territorialidade e Vigilância são as perspectivas que alicerçam o modelo de atenção proposto, que também privilegiou o protagonismo indígena e a interlocução com as práticas tradicionais. Daí o investimento na formação de profissionais de saúde indígenas, a valorização dos especialistas tradicionais e no envolvimento com as comunidades (EPM, 1983, 1987, 1994; MENDONÇA, 1996).

A estratégia de trabalhar nas aldeias e postos com agentes
indígenas de saúde mostrou-se adequada, tanto para se conseguir
aumento significativo da cobertura assistencial, como para uma
maior compreensão por parte da comunidade a respeito das práticas
da medicina ocidental e da educação em saúde. Significa também,
um passo importante na construção da autogestão indígena em
saúde (EPM,1996, p. 27-28).

Alguns dos instrumentos de organização do trabalho implantados pela UNIFESP são utilizados até hoje. Exemplos disso são as fichas individuais de cadastro médico (com número de registro, dados de identificação e fotografia), os protocolos clínicoassistenciais e um sistema local de informações. O número de registro é a principal 
fonte de identificação dos pacientes, consistindo em uma estratégia para evitar erros decorrentes dos homônimos e das trocas frequentes de nome ao longo da vida, uma prática comum entre os indígenas. Os cadastros médicos continuam sendo atualizados em cada etapa de imunização e são a base para atualização do censo populacional. O sistema local de informação foi criado com o objetivo de garantir informações sobre morbimortalidade por etnia, grupo de doenças e faixas etárias, sendo alimentado com informações oriundas da atuação de todos os profissionais. Atualmente, este sistema local de informação ajuda a suprir as deficiências do Sistema de Informações da Saúde Indígena (SIASI), que se encontra ainda em implantação e com grandes dificuldades de operacionalização. Os protocolos clinicoassistenciais foram elaborados a partir dos referenciais do Ministério da Saúde, e orientam a abordagem dos problemas de saúde mais frequentes dentro do perfil epidemiológico local.

O Polo Base é o ponto de apoio dos profissionais da equipe. Durante o tempo em que permanecem em área, os profissionais da EMSI desempenham trabalho nos Polos Base e nas aldeias.

A organização e planejamento local do trabalho são realizados por cada EMSI, considerando as necessidades e especificidades dos territórios de abrangência de cada Polo Base. Algumas atividades do trabalho são comuns, contudo estão incorporadas na organização e na rotina de trabalho de cada Polo Base de maneiras diferentes, sob influência das particularidades de cada território de abrangência.

No dia a dia no Polo Base, o trabalho é realizado na UBS e nos domicílios. Faz parte também da organização do trabalho o contato diário via rádio com as aldeias e com as CASAI. O contato com as aldeias visa dar suporte aos profissionais que lá atuam e acompanhar a evolução dos casos à distância. O contato com a CASAI tem como propósito comunicar demandas de remoção e receber notícias de pacientes que já foram referenciados.

As equipes de campo também realizam viagens para o trabalho nas aldeias, comumente chamadas pelos profissionais de "viagem de vigilância" ou simplesmente "vigilância". Essa denominação é uma referência à vigilância da saúde, modelo de atenção proposto na PNASPI em 2002 sendo praticado no Xingu pela UNIFESP desde o início dos anos 1990. Estas viagens também são tributárias 
do sistema local de saúde implantado pela UNIFESP e tinham como objetivos iniciais o acompanhamento e a supervisão do trabalho dos profissionais indígenas e a realização de atividades de educação em saúde.

As viagens de trabalho nas aldeias têm tempo de duração variável, dependendo dos objetivos, das demandas locais e do grau de dificuldade de acesso. Nas aldeias, a equipe realiza atendimentos de demanda espontânea e de segmentos específicos como idosos, gestantes, crianças menores de cinco anos e portadores de doenças crônicas. Nestes momentos também são realizadas atividades de educação em saúde e supervisão da atuação dos profissionais indígenas que também participam do trabalho. As viagens para aldeia também podem ocorrer de forma mais pontual, motivadas para o atendimento de demandas emergenciais ou outras atividades específicas. O trabalho na aldeia segue um ritmo e tempo diferentes do trabalho no polo. Em geral, no polo a demanda por atendimentos é maior e os casos são mais complexos. O tempo do trabalho é regido pelas atividades na UBS, nos domicílios e no atendimento de chamadas via rádio. Já nas aldeias, mesmo nas maiores, o trabalho costuma seguir um ritmo mais calmo e é interrompido antes do anoitecer.

Atualmente, a UNIFESP atua de forma cooperativa com os indígenas e com o DSEI, apoiando atividades de assistência, formação e gestão por meio de ações específicas e pontuais, e por outras mais contínuas, como a imunização e o apoio matricial no rastreamento do câncer de colo uterino. Recentemente, com a solicitação e apoio das comunidades, a UNIFESP tem investido em ações voltadas ao melhor entendimento e abordagem dos novos agravos à saúde, em especial as doenças crônicas não transmissíveis que tem impactado cada vez mais o perfil epidemiológico local.

\section{7 - A NOÇÃO DE COMPETÊNCIA E A APRENDIZAGEM SIGNIFICATIVA NA SAÚDE}

No senso comum, a palavra competência é associada a uma qualidade pessoal, sendo utilizada para se referir a uma pessoa qualificada ou capacitada para a realização de alguma tarefa ou para a resolução de alguma situação sendo 
comumente utilizada como sinônimo de habilidade. No entanto, o termo competência tem caráter polissêmico, guardando relação semântica com outros termos como autoridade, sabedoria e competição. Assim, competência pode ser definida de diferentes formas e de acordo com diferentes enfoques teórico-conceituais refletindo uma disputa ideológica nos seus diferentes campos de aplicação. Trata-se assim de um conceito multifacetado, plástico e sujeito a ambiguidades. (DELUIZ, 2001a, 2001b; FLEURY e FLEURY, 2001; LIMA, 2005; PEREZ, 2005; MACHADO, 2006; ARAÚJO, 2007; CAMELO e ANGERAMI, 2013).

O enfoque sobre competência profissional surgiu na Europa nos anos 1980, no contexto das modificações no mundo do trabalho e da crise estrutural do capitalismo iniciada nos anos 1970, sendo incorporado pelo meio empresarial no campo de gerenciamento de pessoas. Competência veio substituir o conceito de qualificação, que até então era o referencial do paradigma produtivo e econômico dos modelos fordista/taylorista. Na educação, a noção de competência passou a ser incorporada em meio às demandas de modificação da prática educativa tradicional aplicada na formação profissional, frente às novas exigências e mudanças no setor produtivo. Explicita-se a íntima relação entre os campos do trabalho e da educação. A noção de competência veio substituir a noção de saberes, norteadora da educação tradicional (DELUIZ 2001a, 2001b; FLEURY e FLEURY, 2001; PEREZ, 2005; FELIX e NAVARRO, 2009).

A noção de competência tem sido construída e aplicada em diferentes países a partir de várias linhas teórico-conceituais. ${ }^{10} \mathrm{~A}$ abordagem denominada dialógica trata a noção de competência sob uma perspectiva mais ampla, reconhecendo que ela se dá pela combinação de capacidades e atributos de maneira pessoal, para a realização de ações de uma prática profissional. Esta abordagem também considera a influência do contexto, da cultura, da história e dos valores éticos na construção do conhecimento (DELUIZ, 2001a, 2001b; LIMA, 2005; PEREZ, 2005; CHIESA et al., 2007; ARAÚJO, 2007; KAWATA et al., 2011).

\footnotetext{
${ }^{10}$ As quatro principais correntes são: condutivista, funcionalista, construtivista e a dialógica. Em cada uma delas a noção de competência profissional é trabalhada sob várias perspectivas e com diferentes enfoques. Todas guardam uma relação com o processo produtivo (DELUIZ, 2001a; ARAÚJO, 2007; KAWATA et al., 2011; FRAGELLI E SHIMIZU, 2012).
} 
A concepção dialógica de competência trabalha com 0 desenvolvimento de capacidades ou atributos (cognitivos, psicomotores e afetivos) que, combinados, conformam distintas maneiras de realizar, com sucesso, as ações essenciais e características de uma determinada prática profissional. Assim, diferentes combinações podem responder aos padrões de excelência que regem essa prática profissional, permitindo que as pessoas desenvolvam um estilo próprio, adequado e eficaz para enfrentar situações profissionais familiares ou não familiares. Essa abordagem, considerada holística, precisa ser construída no diálogo entre a formação e o mundo do trabalho, na qual as práticas profissionais são desenvolvidas. (LIMA, 2005, p.372)

A abordagem dialógica de competência reconhece e considera a história das pessoas e das sociedades nos seus processos de reprodução ou de transformação dos saberes e valores que legitimam os atributos e os resultados esperados numa determinada área profissional (LIMA, 2005, p.371).

É nessa perspectiva dialógica que se encontra o conceito de competência defendido por diversos teóricos da educação, entre eles, Philippe Perrenoud. Ele define competência como "a faculdade de mobilizar um conjunto de recursos cognitivos (saberes, capacidades, informações etc.) para solucionar com pertinência e eficácia uma série de situações." (PERRENOUD, 2000, p.1, negrito meu).

Para Perrenoud a noção de competência está vinculada a situações que exigem tomada de decisões. O desenvolvimento de competências é uma consequência adaptativa individual dos sujeitos em seus contextos social, cultural e profissional. Dessa forma, cada sujeito desenvolve de forma bastante particular, competências para resolução de problemas enfrentados ao longo da vida tendo como base os saberes teóricos e práticos adquiridos na vida escolar e cotidianamente por meio das relações sociais (PERRENOUD, 1999, 2000).

Ainda segundo Perrenoud (1999):

$\checkmark$ A competência manifesta-se na ação, na prática reflexiva;

$\checkmark$ Não há competência sem saberes, entretanto, possuir conhecimentos não significa ser competente;

$\checkmark$ Se faltam recursos a serem mobilizados, não há competência; 
$\checkmark$ Se há recursos, mas não podem se mobilizados de maneira adequada, é como se eles não existissem e, assim, não há competência.

Machado (2006) aponta que a noção de competência é composta por seis elementos fundamentais:

Seis são os elementos fundamentais para constituir tal noção: pessoalidade, âmbito, mobilização, conteúdo, abstração e integridade. Em uma frase: a competência é um atributo das pessoas, exerce-se em um âmbito bem delimitado, está associada a uma capacidade de mobilização de recursos, realiza-se necessariamente junto com os outros, exige capacidade de abstração e pressupõe conhecimento de conteúdos. Complementarmente: animais ou objetos não são competentes, não existe uma competência para todos os âmbitos possíveis, é impossível a competência sem uma ação efetiva, a falta de conhecimento é o primeiro sintoma de incompetência, a incapacidade de abstrair o contexto é uma forma de incompetência, e não se pode ser competente sem integrar-se com os outros, sem levar em consideração os outros (Machado, 2006, p.1-2, negrito meu).

A competência profissional pode ser definida como a mobilização de um conjunto de recursos (cognitivos, psicomotores e afetivos) de forma individual pelo profissional, com a finalidade de atuar de forma ativa frente às situações no trabalho em contextos diversos, gerando resultados reconhecidos individual e coletivamente (BARRENNE e ZUÑIGA, 2004; CAMELO e ANGERAMI, 2013).

Competência profissional é a capacidade de articular e mobilizar conhecimentos, habilidades e atitudes, colocando-os em ação para resolver problemas e enfrentar soluções de imprevisibilidade em uma dada situação concreta de trabalho e em um determinado contexto cultural (DELUIZ, 2001b, p.11).

A competência profissional é composta por três elementos: habilidades, conhecimentos e atitudes (BARRENNE e ZUÑIGA, 2004; SAUP et al., 2006; CAMELO e ANGERAMI, 2013) que podem ser assim definidos: 
Quadro 2 - Definições dos elementos que compõem a competência profissional

\begin{tabular}{|l|l|}
\hline \multicolumn{1}{|c|}{ Elemento } & \multicolumn{1}{|c|}{ Definição } \\
\hline Conhecimento & $\begin{array}{l}\text { "Conjunto de conteúdos obtidos predominantemente por meio de } \\
\text { exposição, leitura e reelaboração crítica que possibilitam ao profissional } \\
\text { o domínio cognitivo de um saber e a capacidade de tomar decisões e } \\
\text { resolver problemas em sua área de atuação (intervenção - entendida } \\
\text { como ação direta de cuidado ou educação em saúde)". }\end{array}$ \\
\hline Habilidade & $\begin{array}{l}\text { "Conjunto de práticas adquiridas sobretudo por demonstração, repetição } \\
\text { e reelaboração crítica que fornecem ao profissional o domínio } \\
\text { psicomotor, a perícia de um saber fazer e a capacidade de tomar }\end{array}$ \\
\hline Atitude & $\begin{array}{l}\text { "Conjunto de comportamentos adquiridos por intermédio de observação, } \\
\text { introjeção e reelaboração crítica que conferem ao profissional o domínio } \\
\text { ético e afetivo de um saber ser e saber conviver, além da capacidade } \\
\text { de tomar decisões e de solucionar problemas na sua área de atuação } \\
\text { (intervenção)". }\end{array}$ \\
\hline
\end{tabular}

Fonte: Adaptado de Saupe et al., 2006, p.33.

Quando mobilizados de forma integrada, pertinente e oportuna, conhecimentos, habilidades e atitudes levam à tomada de decisão frente a uma situação concreta.

No Brasil, a crítica ao modelo tradicional de formação foi incorporado à área da saúde no contexto das discussões sobre a reformulação do setor, no final da década de 1980. A inadequação da formação de recursos humanos foi questionada frente às novas demandas da área e às novas propostas de um modelo de atenção à saúde, que culminaram com a formulação do SUS, com princípios doutrinários de universalidade, integralidade, equidade e participação popular. A noção de competência passou a ser norteadora para as mudanças na formação dos profissionais da área da saúde, tornando-se um dos conceitos nucleadores de políticas e programas ${ }^{11}$ do Ministério da Saúde e Ministério da Educação num

${ }^{11}$ Entre as iniciativas mais recentes estão a Política Nacional de Educação Permanente em Saúde (PNEPS), Programa de Educação pelo Trabalho em Saúde (PET Saúde) e o Programa da Reorientação Profissional em Saúde (Pró Saúde) e o Programa de Incentivo 
esforço de reordenar o processo de formação de recursos humanos. Assim, no campo da saúde, o desenvolvimento de competência tem por objetivo uma atuação profissional eficaz, compromissada com a efetivação dos princípios do SUS e com modificação da realidade de saúde (PEREIRA e LAGES, 2013; SIQUEIRA-BATISTA et al., 2013; CONTERNO e LOPES, 2013).

O que se espera é formar profissionais habilitados para responder às necessidades da população brasileira e à operacionalização e à qualificação do SUS, buscando um egresso comprometido com seus princípios (SIQUEIRA-BATISTA et al., 2013, p.161).

O desenvolvimento de competências, no caso do trabalho em saúde, envolve a transmissão de informação, a construção do conhecimento, a aquisição do saber em cenários de prática, a aprendizagem em situações reais de trabalho e a capacidade de ser afetado pelos signos que informam o cotidiano e as necessidades sociais em saúde (CECCIN, 2012, p. 256).

Reconhecendo a insuficiência de treinamentos formais e teóricos e considerando que a aprendizagem se dá na interlocução com os cenários de prática a partir da vivência, reflexão e ação, as propostas de mudança na formação profissional buscaram estratégias que aproximam ensino e serviço. O objetivo foi que a formação fosse orientada pelas demandas do setor saúde e pelas reais necessidades da população. Para isso, foram efetivadas mudanças nas diretrizes curriculares dos cursos de graduação, utilizando novos referenciais pedagógicos. A Educação Permanente foi adotada como estratégia principal da reformulação das práticas educativas agora apoiadas em metodologias ativas de ensino, essencialmente a aprendizagem significativa (SAUPE et al., 2006; BATISTA e GONÇALVES, 2011; CECCIM, 2012; CONTERNO e LOPES, 2013; PEREIRA e LAGES, 2013; SIQUEIRA-BATISTA et al., 2013).

A aprendizagem significativa é uma teoria elaborada na década de 1960 pelo psicólogo Davi Ausubel. Ela se fundamenta no cognitivismo e baseia-se na premissa da existência de uma matriz cognitiva que comporta e organiza todos os conhecimentos e informações que o indivíduo possui e que está em constante 2013; PEREIRA e LAGES, 2013; CONTERNO e LOPES, 2013). 
transformação, servindo de sustentação para novos conhecimentos. A aprendizagem significativa tem como núcleo a interação cognitiva entre novos conhecimentos e os conhecimentos prévios ancorados na matriz cognitiva. Como resultado desse processo, o novo e o antigo sofrem modificações. O novo conhecimento adquire significado para quem aprende e o conhecimento prévio fica mais elaborado, mais estável cognitivamente (MITRE et al., 2008; MOREIRA, 2011; SILVA e SCHIRLO, 2014).

Para que a aprendizagem significativa se efetive são necessários dois requisitos: os novos conhecimentos devem ser potencialmente significativos para o aprendiz que, por sua vez, precisa apresentar uma atitude favorável ao aprendizado, de forma a efetivar uma conexão entre o novo conhecimento e a matriz que já possui (MITRE et al., 2008; MOREIRA, 2011).

\begin{abstract}
A aprendizagem significativa acontece quando aprender uma novidade faz sentido para nós. Geralmente isso ocorre quando a novidade responde a uma pergunta nossa e/ou quando 0 conhecimento novo é construído a partir de um diálogo com o que já sabíamos antes (BRASIL, 2005, p.12)
\end{abstract}

A aplicação da aprendizagem significativa na formação em saúde parte do princípio que o aprendizado se dá na vivência cotidiana do trabalho, na experimentação. $A$ aproximação com a realidade cotidiana confere significado ao aprendizado do profissional. 
OBJETIVO

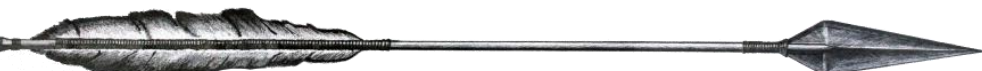




\section{2 - OBJETIVO}

O objetivo deste estudo é analisar a vivência do trabalho do enfermeiro dentro das terras indígenas como um espaço potencial de aprendizagem para que este profissional qualifique a sua prática voltada para a atuação no contexto intercultural.

São objetivos específicos:

$\checkmark$ Identificar a trajetória percorrida pelos profissionais enfermeiros tendo como ponto de partida a inserção no trabalho em saúde indígena com foco na atuação como integrante de EMSI.

$\checkmark$ Identificar os principais aspectos que caracterizam o trabalho do enfermeiro dentro da área indígena estudada e quais as demandas colocadas ao profissional.

$\checkmark$ Identificar e analisar os recursos disponíveis no cotidiano de trabalho que são utilizados pelos enfermeiros para qualificar a sua prática profissional e quais as estratégia utilizadas por esses profissionais para mobilizá-los.

$\checkmark$ Conhecer e analisar as concepções elaboradas pelos profissionais a partir da experiência.

$\checkmark$ Identificar e analisar como a interculturalidade se faz presente na vivência do trabalho de saúde dentro da terra indígena. 
PROCEDIMENTOS METODOLÓGICOS

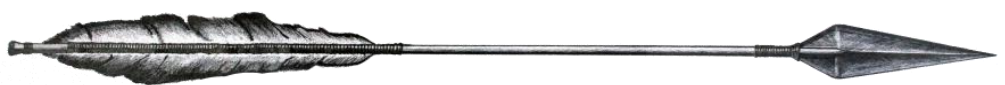




\section{3 - PROCEDIMENTOS METODOLÓGICOS}

O foco deste estudo é a compreensão e a análise das possibilidades de aprendizagem do enfermeiro a partir da vivência do trabalho no interior das áreas indígenas. Para isso, considerou-se a realidade concreta do trabalho como um potencial espaço de aprendizado, fortemente marcado pela interculturalidade. A temática está inserida no campo da Pesquisa Social em Saúde e para sua melhor apreensão, a abordagem qualitativa se fez mais pertinente. A análise demandou contribuições do campo da antropologia e da educação. Trata-se de um estudo exploratório-descritivo do tipo estudo de caso.

\section{1 - O CAMPO DE ESTUDO}

O estudo foi realizado no Parque Indígena do Xingu (PIX), localizado na região nordeste do estado do Mato Grosso, área geográfica do DSEI Xingu. A escolha desse território foi motivada pela facilidade de acesso e pelos conhecimentos que a pesquisadora tem sobre o trabalho em saúde nesta terra indígena, onde já atuou como profissional integrante da Equipe Multidisciplinar de Saúde Indígena (EMSI) durante seis anos.

\section{2 - OS PARTICIPANTES DA PESQUISA}

Os participantes da pesquisa foram enfermeiros que atuam no DSEI Xingu. Foram convidados a participar, voluntariamente, os enfermeiros que já haviam integrado ou estavam integrando as EMSI por um período mínimo de um ano, e que não tivessem participado do processo sistemático de inserção e formação no trabalho realizado pela UNIFESP. Não foram excluídos os profissionais com experiência anterior de trabalho em outros DSEI. 
Para definição destes critérios de seleção, a pesquisadora considerou a EMSI como espaço importante de atuação, e que coloca o profissional em contato permanente com a interculturalidade. O período de um ano foi adotado como tempo mínimo para que o profissional consiga sentir-se mais à vontade com o contexto do trabalho, apropriar-se de suas particularidades e acumular experiências. Isso colaboraria para uma reflexão mais consistente sobre a experiência de trabalho destes enfermeiros e sobre os temas destacados na pesquisa. A exclusão dos profissionais que haviam sido introduzidos no trabalho e formados pela UNIFESP se justifica pela singularidade da atuação desta universidade nesta terra indígena, uma experiência bastante singular, sem equivalentes em outros DSEI. Além disso, este critério buscou garantir um distanciamento da pesquisadora que, durante bastante tempo, esteve envolvida nas atividades de formação e participou ativamente da inserção e acompanhamento de novos profissionais no trabalho.

A partir de informações fornecidas pelo DSEI sobre a data de admissão no trabalho e o histórico de atuação (tempo e local) de cada um dos 38 enfermeiros, foram identificados 17 profissionais que atendiam aos critérios de seleção. Todos estes foram convidados a participar da pesquisa e, apesar de não haver recusa, ao final foram entrevistados 11 enfermeiros (Mapa 4). O limite do número de participantes foi determinado pela logística de deslocamento dentro da terra indígena associada à escala de trabalho dos profissionais. Dessa forma, não participaram os profissionais que estavam de folga ou se desencontraram da pesquisadora durante o período em que a mesma se deslocou pelo território ou permaneceu na sede do DSEI realizando o trabalho.

Para Minayo (2013), a amostra em pesquisas qualitativas não deve ser definida por critérios numéricos, uma vez que a relevância não está no número de participantes e sim nos conteúdos que eles fornecem para a compreensão do objeto do estudo. Segundo esta autora, abrangência, diversidade e profundidade devem ser perseguidas pelo pesquisador. Nesse sentido, apesar de não priorizar o critério numérico, a pesquisadora teve a preocupação de garantir a participação de profissionais que atuam em toda a abrangência do DSEI Xingu. Isso porque cada uma das regiões de saúde do DSEI possui características muito particulares, o que torna a experiência de trabalho em cada uma delas bastante singular. O conjunto de 11 participantes da pesquisa contemplou enfermeiros com experiência de atuação 
nas quatro regiões de saúde e com diferentes histórias de inserção e trajetórias no trabalho, podendo ser considerado satisfatório quanto à abrangência e diversidade. O número de participantes também foi suficiente para satisfazer o critério de saturação, uma vez que as informações obtidas nas entrevistas foram se tornando reincidentes e complementares, atendendo às demandas da pesquisa. 
Mapa 4 - Distribuição dos participantes da pesquisa segundo local de atuação, DSEl ${ }^{\star}$ Xingu 2016.
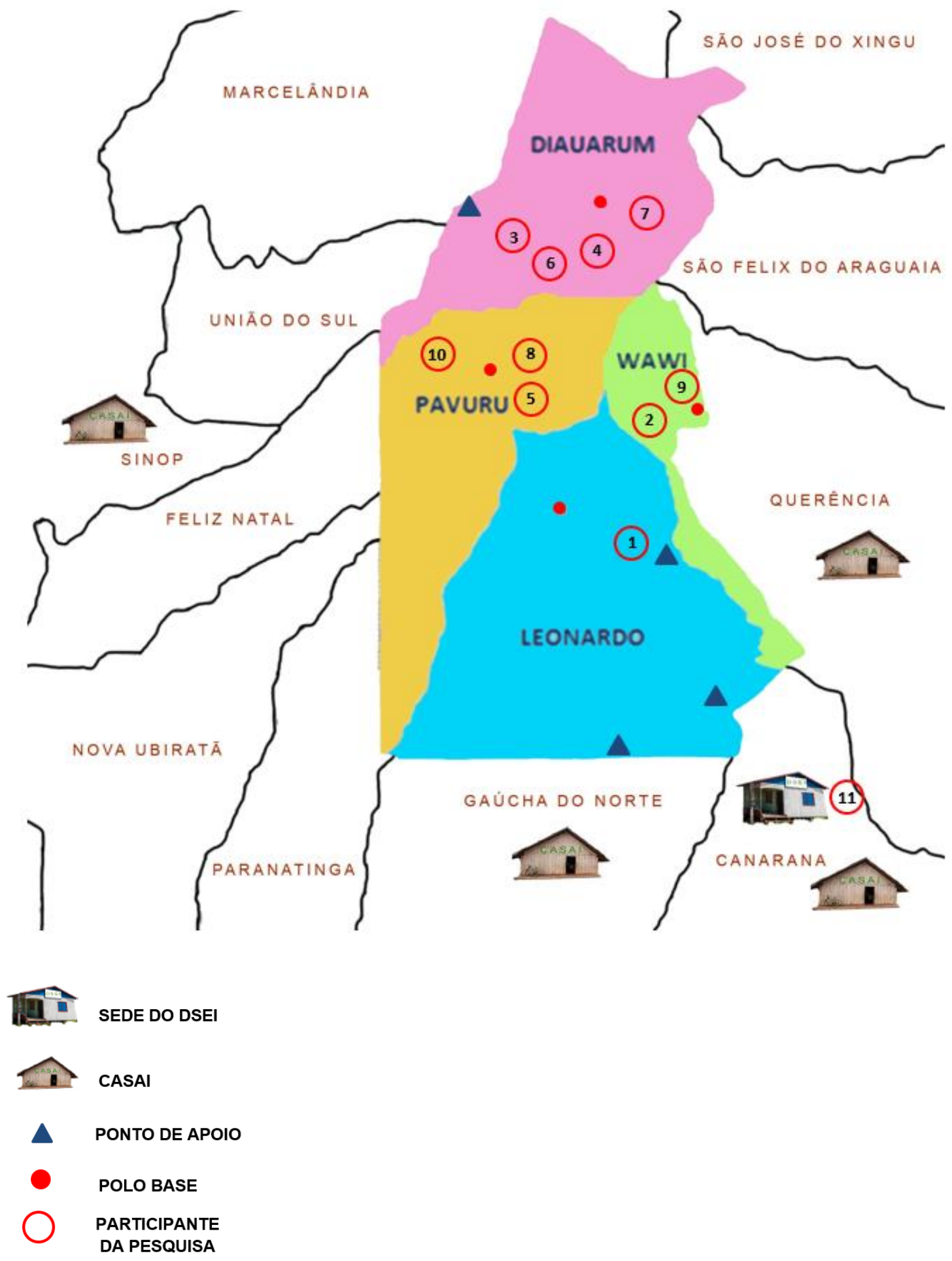

Fonte: Adaptado de ISA, 2011.

*Distrito Sanitário Especial Indígena 


\section{3 - PROCEDIMENTOS PARA COLETA DE DADOS}

Os dados primários foram obtidos a partir de entrevistas individuais semiestruturadas, realizadas pela pesquisadora durante viagem de trabalho ao Parque Indígena do Xingu no segundo semestre de 2016.

Esta técnica se mostra adequada para obtenção dos dados primários, considerando a possibilidade que dá aos participantes de discorrerem sobre o assunto de forma mais livre sendo menos capturados pelo enunciado das questões. Ao entrevistador, a entrevista semiestruturada permite uma maior liberdade para explorar ou direcionar as questões coordenando o diálogo a partir de seus objetivos. Além disso, esta técnica permite uma interação com o participante da pesquisa, o que contribui com a qualidade dos dados (MARCONI e LAKATOS, 2003; MINAYO, 2014).

Previamente à viagem ao campo do estudo, a pesquisadora realizou um primeiro contato por via eletrônica (e-mail) com os 17 profissionais que atendiam aos critérios de seleção com o objetivo de se apresentar, fornecer informações breves sobre a pesquisa e solicitar a colaboração com o estudo. Este primeiro contato foi sucedido de outros para tratar das datas e locais para a realização das entrevistas.

As entrevistas foram realizadas durante uma viagem de trabalho que durou trinta dias, período no qual a pesquisadora percorreu três das quatro regiões de saúde (Wawi, Diauarum e Pavuru) e também esteve na sede do DSEI Xingu. Nesta viagem foi realizada a segunda etapa de imunização. A imunização é uma das atividades nas quais a UNIFESP atua como colaboradora, participando do planejamento, da organização e também da execução do trabalho. Em cada uma das quatro etapas de imunização realizadas ao longo do ano, uma equipe formada por profissionais, alunos e residentes percorre as regiões de saúde. Neste trabalho, além da vacinação, também são realizadas outras atividades e ações de saúde oportunizando a presença dos profissionais nas aldeias, especialmente aquelas de mais difícil acesso. Os profissionais das EMSI são inseridos neste trabalho participando das atividades não apenas nas regiões em que atuam, mas também em outras abrangências. Essa dinâmica permitiu a aproximação prévia e um maior contato entre a pesquisadora e cada um dos participantes da pesquisa colaborando 
para que eles se sentissem menos ansiosos e envergonhados no momento da entrevista.

Nove entrevistas foram realizadas dentro da área indígena com data, local e horário escolhidos pelos participantes. A maioria ocorreu no período noturno, após o trabalho, em local silencioso e reservado, fora do espaço de acomodação da equipe. Duas entrevistas foram realizadas na sede do DSEI. Em geral, as entrevistas ocorreram de forma tranquila e espontânea, com duração média de quarenta e cinco minutos. Dois participantes esboçaram um pouco de nervosismo inicial. Todos demonstraram disponibilidade e satisfação em participar da pesquisa. Foi notável também que, para muitos, a entrevista serviu como um espaço de desabafo, de escuta e uma oportunidade rara de poderem falar sobre a vivência do trabalho e terem suas angústias e inquietações ouvidas.

As entrevistas abordaram a prática profissional e o processo de aprendizagem, tendo como referência o trabalho dentro da terra indígena. Todas as entrevistas foram gravadas e conduzidas a partir de um roteiro com questões fechadas e abertas (Anexo A). As questões fechadas visaram a caracterização dos participantes quanto a gênero, idade, formação e trajetória profissional. As dez questões abertas relacionam-se aos quatro aspectos centrais que circunscrevem o objeto da investigação: 1- como se deu a escolha pelo trabalho na saúde indígena; 2- quais os estranhamentos e conflitos vivenciados no trabalho; 3- o que é preciso aprender para desenvolver o trabalho; e 4- como a vivência do trabalho pode colaborar para a qualificação da prática profissional. Para cada uma das questões foram definidos tópicos sobre informações esperadas e temas a serem abordados, servindo de "ajuda memória" para a pesquisadora no momento da entrevista. O roteiro inicial foi modificado a partir da terceira entrevista, quando uma nova questão (número nove) relacionada ao processo de aprendizagem dos profissionais foi acrescentada. Todas as entrevistas foram gravadas com o consentimento dos participantes.

A primeira pergunta teve como intenção remeter o profissional às vivências iniciais do trabalho, bem como trazer de forma mais espontânea e indireta os primeiros impactos da atuação dentro da área indígena. Essa estratégia foi pensada a partir da experiência pessoal da pesquisadora, que considera que os primeiros dias de trabalho são, em geral, muito intensos e marcantes, e tem muito a dizer sobre esse 
primeiro contato com uma realidade tão diferente. A partir da fala dos participantes, as demais questões do roteiro foram abordadas.

Algumas perguntas precisaram ser melhor explicadas. A questão de número oito foi a mais difícil de ser entendida pelos participantes. Como estratégia, a partir da segunda entrevista, o enunciado da pergunta passou a ser feito de forma diferente sugerindo uma situação hipotética: "Considerando a experiência de trabalho na saúde indígena que você já tem, se eu te dissesse que na próxima semana dois novos enfermeiros, recém-formados, serão contratados para trabalhar dentro de área indígena aqui no Xingu, o que você considera que seria importante ser oferecido ou apresentado a esses profissionais?" Dessa forma, os participantes compreenderam melhor a pergunta. As respostas à pergunta número oito remeteram muito à experiência individual de cada um. Alguns participantes se emocionaram ao responder a questão número nove.

Documentos e informações fornecidos pelo DSEl Xingu e pelo Projeto Xingu/UNIFESP foram considerados dados secundários e utilizados de forma complementar aos dados primários.

A pesquisadora não contou com apoio financeiro de nenhuma instituição de apoio à pesquisa. Os gastos com o transporte para o trabalho de campo foram custeados pela ação de imunização.

\section{4 - PROCEDIMENTOS PARA ANÁLISE DOS DADOS}

A análise dos dados primários foi realizada por meio do método de análise de conteúdo, de acordo com o proposto por Bardin (2016) e Minayo (2014). A análise de conteúdo é definida por Bardin (2016, p.48) como "um conjunto de técnicas de análise das comunicações que utiliza procedimentos sistemáticos e objetivos de descrição do conteúdo das mensagens". Tem por objetivo ir além da compreensão imediata de conteúdos presentes em um texto, sendo capaz de inferir sobre a realidade trazida nas mensagens. Os conteúdos manifestos são o ponto de partida para a análise de conteúdo, rumo à produção de inferências ancoradas em pressupostos teóricos. 
Para proceder a este tipo de análise são propostas várias modalidades técnicas, nas quais os conteúdos do material trabalhado são explorados e analisados, de diferentes formas. No presente estudo foi adotada a análise temático-categorial que, segundo Minayo (2014), consiste em um conjunto de operações sistemáticas de recorte do texto em unidades, seguido do reagrupamento por critérios analógicos visando evidenciar os núcleos de sentido em uma comunicação.

Na prática, a análise foi desenvolvida em três etapas orientadas pelas propostas metodológicas de Bardin (2016) e Minayo (2014), denominadas: 1 - pré-análise; 2 exploração do material e 3 - tratamento dos resultados obtidos e interpretação.

A etapa de pré-análise consistiu em uma aproximação com o conteúdo por meio da transcrição integral das entrevistas. Em seguida foi realizada uma leitura intuitiva, acompanhada do registro assistemático das primeiras impressões e ideias apreendidas. Neste momento, atentou-se também para a ausência de colocações dos participantes sobre questões importantes relacionadas aos temas abordados na entrevista.

A exploração do material compreendeu o recorte dos conteúdos, extraindo unidades de registro compostas por temas comuns nas falas de todos os participantes e considerados relevantes dentro do estudo. Posteriormente, tais unidades de registro foram reagrupadas analogicamente dando origem a temas de análise primários, elencados a partir dos indícios apreendidos na fase de aproximação (emergiram do contexto das respostas), dos objetivos da pesquisa e dos conceitos que apoiam a análise.

Os temas primários foram novamente trabalhados e reagrupados, dando origem a cinco temas finais. São eles: 1- Motivos da escolha por trabalhar em área indígena; 2- A vivência da imersão na área indígena; 3- O caminho da construção de competência; 4- As concepções a partir da experiência e 5- O imperativo da interculturalidade (Anexo B).

Para efeito da organização, o conteúdo da análise destes cinco temas é apresentado em tópicos e subtópicos na sessão resultados e discussão. Apesar de apresentados separadamente, os temas mantém clara articulação entre si e esboçam o percurso percorrido pelos participantes desde a inserção no serviço. 
Os conteúdos relativos ao processo de aprendizado, foco do estudo, foram analisados com apoio no conceito de competência profissional. Dessa forma, o aprendizado foi entendido como desenvolvimento de competências que qualificam o profissional enfermeiro para o exercício de sua prática no contexto do trabalho dentro da área indígena. A questão central colocada pela pesquisa foi a seguinte: quais os recursos mobilizados pelos profissionais enfermeiros para a qualificação de sua prática profissional? Como dito anteriormente, o conceito de competência utilizado no estudo está situado no campo da educação, elaborado na perspectiva de abordagem dialógica do termo. Elaborações de vários autores sobre a competência profissional no trabalho em saúde também foram utilizadas como apoio.

A análise também se ancorou em conceitos do campo da antropologia, entre eles o de interculturalidade, considerada como elemento fundamental que contextualiza o trabalho na saúde indígena.

\section{5 - CUIDADOS ÉTICOS}

Foram seguidas as recomendações para pesquisa envolvendo comunidades indígenas expressas na resolução n466/12 do Conselho Nacional de Saúde (CNS). Dessa forma, após a anuência do Conselho Distrital de Saúde Indígena (CONDISI) do DSEI Xingu (Anexo C), o projeto de pesquisa foi submetido ao Comitê de Ética em Pesquisa (COEP) da Faculdade de Saúde Pública da Universidade de São Paulo (CAAE n53783616.6.0000.5421), sendo aprovado em agosto de 2016.

As informações sobre a pesquisa e o caráter confidencial dos dados foram esclarecidos pela pesquisadora pessoalmente a cada participante, e a concordância em participar do estudo foi expressa por estes individualmente, por meio da assinatura do Termo de Consentimento Livre e Esclarecido (Anexo D).

A autorização para utilização dos dados secundários foi fornecida pelo coordenador do DSEI Xingu (Anexo E) e pelo coordenador da Unidade de Saúde e Meio Ambiente do Departamento de Medicina Preventiva UNIFESP, onde está inserido o Projeto Xingu (Anexo F). 
Os resultados da pesquisa serão disponibilizados ao DSEI Xingu, ao CONDISI do DSEI Xingu e aos participantes da pesquisa. 
RESULTADOS E DISCUSSÃO 


\section{4 - RESULTADOS E DISCUSSÃO}

\section{1 - OS PARTICIPANTES E SUAS TRAJETÓRIAS ATÉ O TRABALHO NA SAÚDE INDÍGENA}

Os participantes da pesquisa têm entre 26 e 39 anos e não há uma predominância relevante entre os sexos, sendo cinco enfermeiras e seis enfermeiros. Este equilíbrio não reflete a realidade do DSEI, onde $76 \%$ dos enfermeiros são do sexo feminino. Contraria também o perfil da enfermagem em nosso país, uma profissão que, como já foi colocado anteriormente, apesar de um crescente aumento do contingente masculino na categoria, ainda é predominantemente feminina.

O tempo de formação varia entre três e sete anos, sendo que apenas dois participantes graduaram em instituições públicas. Seis dos onze participantes foram formados em uma mesma instituição particular, localizada em Mato Grosso no limite com o estado de Goiás. Apenas dois não possuem especialização, enquanto que outros dois possuem especialização em Saúde Indígena. Para cinco deles, a saúde indígena foi o primeiro emprego.

Três residem no mesmo município onde se localiza a sede do DSEI, sendo que apenas um dos participantes reside fora do estado do Mato Grosso, na região de divisa com o estado de Goiás.

A predominância de profissionais que se formaram e residem na região pode ser explicada pela forma de admissão no trabalho. Desde 2011, o ingresso no trabalho no DSEI tem acontecido por meio de um processo seletivo coordenado pela instituição contratante, a Associação Paulista para o Desenvolvimento da Medicina (SPDM).

O processo se inicia com a divulgação do edital eletrônico. No momento da inscrição, os candidatos fornecem informações sobre formação e atuação profissional, que servirão de base para uma pré-seleção em que a experiência prévia com o trabalho na saúde indígena é valorizada. Para os candidatos préselecionados, as próximas etapas são a prova escrita e a entrevista presencial, 
ambas de caráter eliminatório e realizadas no município sede do DSEI. Acatando as disposições da Convenção 169 da OIT, sobre o direito de consulta e participação dos indígenas em decisões relacionadas ao uso, gestão e preservação de seus territórios, a SPDM tem garantido a participação do controle social indígena no processo de seleção, especialmente durante as entrevistas. Os processos seletivos têm validade de um ano e geram um banco de cadastros reserva, que consiste em uma lista de espera de candidatos aprovados que poderão ser chamados para o trabalho, ocupando futuras vagas. O banco de cadastros reserva possibilita maior rapidez no preenchimento das vagas, diminuindo o tempo de espera por um novo profissional, especialmente dentro de área, uma queixa frequente dos indígenas ${ }^{12}$.

A realização da prova escrita e da entrevista no município sede do DSEI, numa certa medida, favorece os candidatos que residem na região, uma vez que estes terão menores gastos financeiros com as viagens.

Sobre o tempo de trabalho no DSEI, a média do grupo é de dois anos e meio. Por falta de informações, não é possível afirmar se há ou não alta rotatividade de profissionais. Com exceção de dois participantes, todos os demais atuam no mesmo local desde o ingresso no trabalho.

Cada um dos participantes desenhou uma trajetória bastante singular, que se inicia com as motivações para o trabalho na saúde indígena e segue ao longo da experiência de atuação neste campo. Em comum, todos vivenciaram situações de surpresa, frustração, conflito, alegria e, sobretudo, de muito aprendizado.

\section{Participante 1}

É do sexo feminino, tem 30 anos, é casada e reside a $327 \mathrm{~km}$ da sede do DSEI. Graduou-se há três anos em uma instituição particular da região, onde também concluiu a especialização em Saúde Indígena (presencial, iniciada durante a graduação). A Saúde Indígena é o seu segundo emprego como enfermeira. Antes, trabalhou em um hospital particular de um pequeno município da região por seis meses. O primeiro contato com os indígenas ocorreu antes da graduação, quando

\footnotetext{
${ }^{12}$ Informações fornecidas pela SPDM, instituição conveniada responsável pela contratação de profissionais, em janeiro de 2017.
} 
atuava voluntariamente como técnica de enfermagem em um hospital público regional que atende aos indígenas. Durante a graduação, a temática da saúde indígena foi abordada na disciplina de nutrição. $O$ interesse por este campo de atuação ocorreu durante o curso de pós-graduação, cujos conteúdos, na maioria sobre a etnia Xavante, despertaram nela curiosidade sobre os modos de vida dos indígenas. Outra motivação para o trabalho foi a possibilidade de colaborar para que os indígenas tivessem uma atenção à saúde mais digna. A escolha pelo DSEI Xingu foi motivada pela presença de amigos (indígenas e não indígenas) que também trabalham no DSEI. Está no DSEI Xingu há dezoito meses, sempre como integrante de EMSI.

\section{Participante 2}

É do sexo feminino, tem 34 anos, é casada e reside a $326 \mathrm{Km}$ da sede do DSEI. Graduou-se há cinco anos em uma instituição particular da região. Antes da saúde indígena trabalhou por três anos em um hospital municipal, nos setores de vigilância epidemiológica e faturamento. Está no DSEI Xingu há pouco mais de dois anos como integrante de EMSI. O primeiro contato com a temática da saúde indígena ocorreu durante a graduação em uma disciplina específica. Após formada, trabalhou voluntariamente em um hospital regional onde teve contato com pacientes indígenas, em sua maioria Xavante, tendo vivenciado situações de conflito relacionadas à interculturalidade que Ihe despertaram curiosidade e reflexão. Além da curiosidade e do interesse, outra motivação para a atuação neste campo de trabalho foi por associá-lo à possibilidade de aprender mais e poder ajudar os indígenas, que são descritos por ela como pessoas que realmente precisam. Além disso, o trabalho dentro de área indígena representa também uma espécie de desafio pessoal e uma possiblidade de confrontar a realidade de trabalho no ambiente hospitalar. A escolha pelo DSEI Xingu não foi intencional, também participou de processo seletivo no DSEI Xavante, mas, não foi aprovada. 


\section{Participante 3}

É do sexo feminino, tem 26 anos, é solteira e reside a $326 \mathrm{Km}$ da sede do DSEI. Graduou-se há quatro anos em uma instituição particular da região. Possui especialização em Urgência e Emergência, Saúde Pública e Enfermagem do Trabalho, cursadas também em instituição particular (presenciais e realizadas simultaneamente). O primeiro contato com a temática da saúde indígena ocorreu na graduação em uma disciplina específica, cujo conteúdo abordou apenas história do indígena de antigamente, além do estágio curricular em aldeias Xavante. $\mathrm{O}$ desejo de trabalhar dentro de área indígena veio associado com a possibilidade de vivenciar uma experiência nova. A saúde indígena foi o primeiro emprego, sendo que atua no DSEI Xingu como integrante de EMSI. A escolha pelo DSEI Xingu não foi intencional, também participou de processo seletivo no DSEI Xavante, mas, não foi aprovada. Atualmente, afirma que não se vê trabalhado fora de área indígena.

\section{Participante 4}

É do sexo masculino, tem 24 anos, é solteiro e reside a $406 \mathrm{Km}$ da sede do DSEI. Graduou-se há cinco anos em uma instituição particular do estado de Goiás onde também concluiu a especialização em Saúde Pública (presencial, iniciada durante a graduação). $O$ interesse pela saúde indígena foi despertado pelo contato com indígenas que residiam no município onde ele trabalhava e também pelos relatos de amigos, que descreviam o trabalho em área indígena como muito bom, apesar das dificuldades. Havia também um interesse de conhecer uma outra forma de olhar a saúde, uma realidade de trabalho diferente da cidade, a qual classifica como burocrática. Antes do trabalho no DSEI Xingu, trabalhou no Programa de Saúde da Família (PSF) rural e no Centro de Atenção Psicossocial (CAPS) de um município da região, durante um ano. Está no DSEI Xingu há quase quatro anos atuando como integrante de EMSI. A escolha do DSEI Xingu não foi intencional, foi aprovado no primeiro processo seletivo que participou. 


\section{Participante 5}

É do sexo masculino, tem 39 anos, é solteiro e reside a $90 \mathrm{Km}$ da sede do DSEI. Graduado há quatro anos em uma instituição particular da região, tem especialização em Saúde Indígena e Saúde Pública também em instituição particular (presenciais, cursados simultaneamente e iniciados durante a graduação). O primeiro contato com a saúde indígena foi anterior à graduação, atuando como técnico de enfermagem em aldeias Xavante no Mato Grosso. Naquele momento, o trabalho surgiu como uma oportunidade de iniciar a vida profissional associado ao desafio pessoal de residir fora do ambiente urbano. Durante a graduação, a temática também foi abordada em disciplina específica. A saúde indígena foi o segundo emprego como enfermeiro, após um ano atuando como monitor na faculdade onde estudou. Decidiu retornar para o trabalho dentro de área indígena considerando que a experiência anterior havia sido positiva, além da oportunidade de emprego e remuneração satisfatória. Está há quase três anos no DSEI Xingu, como integrante de EMSI. Além do DSEI Xingu, participou de processos seletivos de dois outros DSEI da região amazônica motivado pela vontade de conhecer outras culturas. A escolha do DSEI Xingu não foi intencional e para a participação no processo seletivo, contou com ajuda financeira de um amigo. Atualmente, relembra as dificuldades e os contratempos que enfrentou quando ainda atuava como técnico de enfermagem, mas, considera que, apesar disso, não enfrentou grandes dificuldades de adaptação ao trabalho. A principal mudança advinda da atuação como enfermeiro, quando comparada a atuação como técnico de enfermagem, é o aumento da responsabilidade. Hoje, se considera mais preparado para o trabalho e entende melhor o seu papel como enfermeiro.

\section{Participante 6}

É do sexo feminino, é solteira, tem 28 anos e reside no município onde está localizada a sede do DSEI. Graduada há cinco anos em instituição particular no interior do estado de São Paulo. Tem especialização em Saúde Pública, também cursada em instituição particular (modalidade à distância). Iniciou curso de especialização em Saúde Indígena na mesma instituição, mas interrompeu porque não conseguiu conciliar com o trabalho em área indígena. Teve contato com a 
temática indígena através de uma disciplina na graduação cujo conteúdo, que considera superficial, abordou principalmente a cultura e a epidemiologia. A saúde indígena foi o primeiro emprego e as maiores motivações para este trabalho foram a curiosidade despertada pelo frequente contato com indígenas na cidade e os relatos de amigos que atuam dentro de áreas indígenas. A escolha do DSEI Xingu foi motivada pela possibilidade de permanecer perto da família. Buscou a vaga do trabalho por seis meses, período no qual participou de vários processos seletivos. Atua no DSEI Xingu há cinco anos, sendo os três últimos como integrante de EMSI. Já trabalhou em duas das quatro regiões de saúde do DSEI. Atuou também como Referência Técnica do programa de imunização.

\section{Participante 7}

É do sexo masculino, tem 36 anos, é casado e reside a $326 \mathrm{Km}$ da sede do DSEI. Graduado há sete anos em instituição particular em Mato Grosso. Concluiu especialização em Urgência e Emergência e Enfermagem do Trabalho também em instituição particular (presencial, cursados simultaneamente). Em nenhum momento do seu itinerário formativo acadêmico a temática indígena foi abordada. Antes da saúde indígena, trabalhou em Enfermagem do Trabalho, Atendimento Móvel de Urgência, PSF e foi diretor distrital de saúde. A principal motivação para a procura deste campo de trabalho foi a curiosidade, despertada pelos relatos de familiares e amigos que trabalham em áreas indígenas e pelos contatos esporádicos com indígenas em um município do Mato Grosso. A motivação para escolha do DSEI Xingu veio pela beleza da terra indígena retratada em um filme. Atua há quatorze meses no DSEI Xingu como integrante de EMSI.

\section{Participante 8}

É do sexo feminino, tem 31 anos, é solteira e reside a $607 \mathrm{Km}$ da sede do DSEl. Graduada há seis anos em instituição federal no estado do Mato Grosso. Tem especialização em Gestão de Redes e Serviços de Saúde, Urgência e Emergência e Saúde Indígena, as duas últimas na modalidade à distância. Antes do trabalho em saúde indígena, atuou em serviço de urgência e emergência e saúde mental 
assumindo cargos assistenciais, de coordenação e gerenciais. $O$ interesse pelo trabalho na saúde indígena foi despertado pelo contato com indígenas durante estágio curricular em um hospital regional na graduação. Durante o curso de pósgraduação, o interesse foi reforçado especialmente pelos os conteúdos sobre política de saúde, educação em saúde e a abordagem sobre vulnerabilidade das mulheres e crianças indígenas. $O$ trabalho também representou uma oportunidade de realizar um desejo pessoal de trabalhar com pessoas mais humildes. Trabalha no DSEI Xingu há pouco mais de dois anos como integrante de EMSI.

\section{Participante 9}

É do sexo masculino, tem 38 anos, é casado e reside a $176 \mathrm{Km}$ da sede do DSEI. Graduado há três anos em instituição particular da região, onde também iniciou curso de especialização em Saúde Indígena que não concluiu. O primeiro contato com a saúde indígena ocorreu quando ainda era técnico de enfermagem no DSEI Xavante onde trabalhou por nove anos e saiu devido a fatores políticos internos. Aquele era o seu segundo emprego após a saída do exército (onde fez o curso técnico), e após um ano de trabalho em PSF. A motivação para o trabalho em saúde indígena surgiu a partir dos relatos de colegas que também atuavam na área e discorriam sobre a satisfação com o trabalho e a boa remuneração. No DSEI Xavante iniciou o trabalho como integrante de EMSI, mas também atuou no setor de informações do DSEI e na CASAI, onde despenhou atividades assistenciais e administrativas. Durante a graduação, a saúde indígena foi abordada principalmente nos conteúdos sobre a cultura Xavante e sobre a organização da atenção à saúde. O primeiro emprego como enfermeiro foi no DSEI Xingu, após mais de um ano de graduação. Participou também de processo seletivo no DSEI Xavante, mas não foi selecionado. A escolha pelo DSEI Xingu foi motivada pela experiência positiva na saúde indígena, pela vontade de conhecer novas realidades e pela beleza do local retratada em um filme. Está no DSEI Xingu há vinte meses como integrante de EMSI. 


\section{Participante 10}

É do sexo masculino, tem 33 anos, é solteiro e reside no município onde está localizada a sede do DSEI. Graduado há quatro anos em instituição particular da região. Tem especialização em Urgência e Emergência, Enfermagem do Trabalho e Saúde da Família também em instituição particular (presenciais, cursadas simultaneamente e iniciadas durante a graduação). Está cursando especialização em Saúde Indígena, na modalidade à distância em instituição pública federal. Após a graduação, realizou trabalho voluntário em PSF e no hospital municipal por quase um ano. A saúde indígena foi seu primeiro trabalho. $O$ interesse pela área foi despertado na graduação quando teve contato com o tema, através de disciplina, e também com indígenas Xavante, no estágio curricular. Além disso, conhece pessoas que atuam na área e tem contato frequente com os indígenas no município onde reside. Outro fator motivador para o trabalho na terra indígena é a afinidade com a geografia local, com o ambiente e a possibilidade de uma interação mais próxima com os indígenas e com a cultura. Está no DSEI Xingu a pouco mais de dois anos atuando como integrante de EMSI.

\section{Participante 11}

É do sexo masculino, tem 31 anos, é solteiro e reside no município onde se localiza a sede do DSEI. Graduado há sete anos em instituição federal no estado do Mato Grosso. Tem especialização em Saúde Indígena em instituição particular (presencial). A primeira experiência profissional como enfermeiro ocorreu na saúde indígena, logo após a graduação em um trabalho temporário (de trinta dias), de caráter emergencial, dentro de área indígena no DSEI Araguaia. Define esta experiência de trabalho como confusa e sem objetivos claros. Depois disso, atuou em um hospital municipal da região por aproximadamente um ano. Posteriormente, iniciou o trabalho no DSEI Xingu após ser aprovado em processo seletivo. As dificuldades com a experiência anterior foram superadas e a motivação para o trabalho na saúde indígena veio da curiosidade a partir do contato com amigos e namorada que trabalhavam no DSEI Xingu. O fator financeiro também foi motivador. Está no DSEI Xingu há quase quatro anos. Já foi integrante de EMSI em duas 
regiões de saúde diferentes por mais de dois anos, já atuou na CASAI de Canarana e agora é o Responsável Técnico pelo programa de tuberculose.

\section{2 - PORQUE EU VENHO E O QUE TRAGO COMIGO:} MOTIVAÇÕES, EXPECTATIVAS E CONCEPÇÕES NA CONSTRUÇÃO DE UM SENTIDO PARA O TRABALHO NA SAÚDE INDÍGENA.

\section{Antes de conhecer isso tudo aqui, até aquele filme Xingu me inspirou muito para estar aqui também.}

(Participante 9)

Entre os participantes, foram identificadas diversas motivações que os levaram a se inserirem no trabalho na saúde indígena. Duas delas foram comuns a todos do grupo: a curiosidade e a vontade de conhecer mais sobre a cultura, o modo de vida dos povos indígenas e sobre o trabalho em saúde com este grupo populacional. Tal interesse tem suas origens no contato prévio com os indígenas ou com a temática da saúde indígena por meio da vivência pessoal, durante a formação acadêmica ou por intermédio de relatos de profissionais que já tinham experiência com o trabalho.

As informações recebidas durante a graduação ou pós-graduação variam entre os participantes, e, em geral, são relacionadas à organização da assistência à saúde, ao trabalho dentro de área, à situação de saúde, e à cultura indígena sendo carregadas de particularidades regionais. Dessa forma, a maioria dos participantes teve contato e recebeu informações sobre os indígenas Xavante (que residem na região) e sobre a organização do trabalho no respectivo DSEI. Apenas o participante cinco relatou ter recebido informações específicas sobre o trabalho do enfermeiro dentro da terra indígena. Agora, após o contato com o campo, todos qualificam as informações a que tiveram acesso como insuficientes, superficiais e, até mesmo, equivocadas.

Foi conversado mais mesmo sobre a cultura. As doenças que mais acometiam aqui na região. Só que era muito pouco o que eles estavam oferecendo para nós, até porque, eles não tinham conhecimento real (Participante 6). 
Na verdade, estudava mais a questão da CASAl, polos, aldeias. Mas, para quem conhecia já a saúde indígena, eu acho que era um conteúdo bem fraco. Professores não qualificados também. Mas, estudava mais a questão cultural, o que é polo, CASAl, essas coisas. [...] lá falavam mais do Xavante, a região de Paranatinga, o que era CASAI, o que era polo, polo Campinápolis, polo Água Boa. Essas coisas, só para entender mesmo a questão (Participante 9).

Os relatos de profissionais com experiência, além de fornecerem informações sobre o trabalho na saúde indígena, reforçaram a caracterização deste campo, avaliado positivamente, apesar das dificuldades.

Eu não conhecia o trabalho, mas, eu ouvia falar muito. O meu cunhado já trabalhou na saúde indígena. Ele é médico também. Trabalhou em Confresa. Ele trabalhou lá, ele me falava como era tudo. Aí eu fiquei interessado em conhecer (Participante 7).

Tinha vários amigos, colegas que trabalhavam na saúde indígena e eles sempre falavam, mas, eles falavam bem. Falavam das dificuldades, mas, no contexto geral, eles gostavam muito (Participante 4).

Apesar de muito mencionados pelos participantes, a curiosidade e o interesse não são os únicos componentes da motivação para o trabalho. O ganho financeiro, a proximidade geográfica da família, a oportunidade de emprego, e expectativa de realização profissional e pessoal, foram como fatores motivadores identificados neste grupo. Até mesmo as belezas do PIX, bem como a magia e misticismo dos rituais indígenas, retratados com frequência pela mídia, foram citados como um atrativo a mais.

E daí o que pesou mesmo para mim no poder de decisão foi o financeiro. Lá eu ainda ia ganhar um pouco menos, ainda estava me engajando, não tinha um salário fixo. Era tanto por hora aula, recém formado, aprendendo. E eu queria algo mais rápido e acabei vindo para o Xingu (Participante 5).

Quando eu assisti ao filme Xingu, e eu conheci mais sobre aqui, eu tive mais vontade de fazer o seletivo do DSEI Xingu. Quando eu vi o filme e vi o quanto aqui era bonito, eu falei: "Opa, (vou) fazer o seletivo para lá" (Participante 7). 
A presença do enfermeiro na saúde indígena pode ser entendida como um desdobramento das mudanças ocorridas na profissão em nosso país, no que diz respeito a oferta de formação, inserção no campo de trabalho e remuneração.

A expansão da oferta de cursos de graduação em enfermagem no Brasil nas duas últimas décadas tem ocorrido de maneira desordenada, com maior concentração no setor privado e de forma desigual nas diferentes regiões do país (DUMÊT FERNANDES et al., 2013). No estado do Mato grosso, o aumento significativo da oferta de cursos de graduação em enfermagem ocorreu de forma mais tardia, a partir de 2006. No período entre 2005 e 2010 o aumento foi de $320 \%$ e veio acompanhado da interiorização dos cursos e predominância de instituições privadas (DE MATTOS CORRÊA et al., 2014).

Uma recente pesquisa de abrangência nacional sobre o perfil da enfermagem ${ }^{13}$, apontou que essa categoria profissional representa $50 \%$ da força de trabalho da saúde no país, estando fortemente inserida no SUS com mais da metade dos bconstituem também outros aspectos do campo de trabalho deste profissional.

Nesse sentido, a Saúde Indígena tem se configurado como um campo de atuação atrativo por oferecer uma oportunidade de emprego com salários diferenciados.

Em estudos realizados com enfermeiros nos DSEI Manaus e Porto Velho, oportunidade efetiva de emprego, a melhor remuneração, o reconhecimento profissional e a aptidão para trabalhar em área, foram as motivações colocadas pelos enfermeiros para o trabalho na saúde indígena. Para os recém-formados, a saúde indígena representou uma oportunidade efetiva para o primeiro emprego. Para os que já tinham experiência de atuação em outras áreas, o salário foi apontado como principal motivador para o ingresso na saúde indígena (OLIVEIRA, 2013; MACKERTE e OTT, 2014).

Apenas os participantes cinco, seis, nove e onze falaram diretamente sobre a motivação financeira.

\footnotetext{
${ }^{13}$ Resultados da pesquisa Perfil da Enfermagem no Brasil, de iniciativa do Conselho Federal de Enfermagem (COFEN) e desenvolvida pela Fundação Oswaldo Cruz (FIOCRUZ). Disponível em: <https://portal.fiocruz.br/pt-br/content/pesquisa-inedita-traca-perfil-daenfermagem-no-brasil >. Acesso em: 15 NOV. 2015.
} 
Porque não e fácil vir para cá. Todo mundo que vem, vem porque precisa. Realmente está precisando. Um pai de família não vai deixar a família em Minas Gerais para vir para cá porque tem amor, não vai vir para cá por amor. Eu acho que é por necessidade também, na maioria das vezes (participante 6).

Financeiro, curiosidade em conhecer esse tipo de trabalho, eu acho que essas são as duas palavras que definem, financeiro e curiosidade (Participante 11).

Atualmente, os salários pagos aos enfermeiros que atuam dentro de área indígena, estão acima dos praticados no setor público em algumas regiões do país. No DSEI Xingu, em dezembro de 2016 o salário do enfermeiro de EMSI era de 7.410,21 reais $^{14}$. De acordo com a já citada pesquisa, no estado do Mato Grosso, menos de $50 \%$ dos enfermeiros que atuavam no setor público no ano de 2013 tinham rendimento mensal acima de $3.000,00$ reais. Destes apenas $14,1 \%$ recebiam mais que $5.000,00$ reais mensais ${ }^{15}$.

A falta de oportunidade de trabalho também não foi colocada de forma explícita pelos participantes. Apesar disso, a dificuldade com o primeiro emprego parece ser uma realidade. A necessidade se inserir no mercado de trabalho e de superar as dificuldades de oferta de emprego na região, junto com o desejo de manter a proximidade com sua família, levaram a participante seis a insistir em realizar diversos processos seletivos no DSEI Xingu, por pelo menos seis meses, até conseguir se inserir no trabalho. Os participantes dois e dez realizaram trabalho voluntário após a graduação com o objetivo de adquirir experiência profissional. 0 participante nove atuou como técnico de enfermagem por mais de um ano após a conclusão da graduação.

Para alguns participantes, o ingresso no trabalho na saúde indígena também representou uma oportunidade de realização e de satisfação de expectativas profissionais e pessoais diversas, que dialogam com a história particular de cada um

\footnotetext{
${ }^{14}$ Dados fornecidos pela SPDM, instituição conveniada responsável pela contratação de profissionais para o DSEI Xingu, em janeiro de 2017.

15 Pesquisa Perfil da Enfermagem no Brasil, de iniciativa do Conselho Federal de Enfermagem (COFEN) e desenvolvida pela Fundação Oswaldo Cruz (FIOCRUZ) dados regionais. Disponível em: <http://www.cofen.gov.br/perfilenfermagem/>. Acesso em: 20 ago. 2016.
} 
deles. Entre as expectativas, o desejo de atuar em um contexto que fizesse uma contraposição à experiência profissional prévia, de desenvolver um trabalho mais próximo ao paciente e de ter o trabalho reconhecido.

Eu vim com o intuito de que ia vir para uma aldeia, realizar um trabalho e eu ia conseguir fazer uma análise se estava tendo resultado ou não. Além de viver novas experiências, também aprender uma nova forma de olhar a saúde. Eu acho que tudo que vem para a gente acrescenta, e eu queria acrescentar algo mais, porque para mim eu não estava feliz da forma que estava (Participante 4).

Eu tinha o desejo de ser enfermeira assistencial mesmo. Saúde da família, botar a mão na massa mesmo. Porque a gente mexe mais com papel, estratégias para mudar. Eu queria ver diferença com a família, com as pessoas, pessoalmente. Eu tinha vontade de viver essa experiência e a saúde indígena veio como uma oportunidade (Participante 8).

Para os participantes dois e cinco os desafios impostos pelo trabalho na saúde indígena também foram um atrativo. O enfrentamento do diferente, do adverso, do difícil passou a ser um desafio profissional e pessoal.

Que eu tenho as minhas dificuldades, minhas limitações e eu só consigo aprender quando não tem ninguém para ajudar e eu sou obrigada a fazer. Então eu acho que lá (no ambiente hospitalar) eu tinha muita gente para ajudar, fazer as coisas por mim. E aqui não. Sou eu, só eu, e eu tenho que me virar. Então eu falei: "Para eu aprender mais, para eu tirar alguns medos que eu tinha, eu tinha que me desafiar" (Participante 2,).

E eu fiquei ali, tinha muita vontade de trabalhar porque eu tinha acabado de terminar o curso. E teve um desafio meio que pessoal porque toda vida eu fui uma pessoa muito urbana, da cidade e o meu pai falou assim para mim: "Você não vai ficar. Você é da cidade, você não vai conseguir" (Participante 5).

Foi possível identificar que o contato prévio com a temática indígena funciona não apenas como um gatilho que desperta o interesse em conhecer mais sobre este universo tão diferente, mas também como fonte para a construção de um imaginário que o profissional carrega consigo quando se insere no trabalho. Quase todos os participantes expressaram ter um imaginário prévio sobre o trabalho, a permanência 
dentro da terra indígena e sobre o convívio com os indígenas, marcado por um ponto em comum: a certeza de que seria uma experiência diferente e de que, provavelmente, enfrentariam dificuldades.

Eu só sabia que eu ia entrar em área e que o trabalho não é igual ao da cidade, é bem diferenciado mesmo (Participante 3).

Isolamento geográfico e falta de estrutura, em um cenário típico de aventuras, também fazem parte desse imaginário. A Saúde Indígena representa uma aventura? Um risco?

Eu imaginava que ia ser no meio de uma mata mesmo, que não atinha a estrutura de uma UBS, que não tinha nada disso aqui, que a gente ia ficar acampada, uma outra imaginação mesmo, completamente diferente da realidade que é aqui dentro (Participante 3).

[...] porque eu vim com um pensamento de que as condições eram piores. Mas, na verdade, eu me deparei com uma estrutura muito melhor do que eu pensava (Participante 4).

Apesar da certeza da diferença, no que diz respeito à organização do trabalho e à atuação profissional, os participantes descreveram um imaginário composto por elementos e características trazidos de suas experiências prévias. Ou seja, apesar de identificarem que o contexto seria diferente, de imediato, parecem não terem conseguido reconhecer as possíveis implicações dessa diferença na organização do trabalho e na atuação do enfermeiro. Dessa forma, imaginavam um cenário composto por vários elementos de suas práticas anteriores, traduzindo uma expectativa de atuação muito semelhante à que experimentaram em outros espaços de trabalho. As falas descrevem a expectativa de uma atuação do enfermeiro como integrante de uma equipe multiprofissional de saúde, composta predominantemente por médico e profissionais de enfermagem, em um processo de trabalho marcado pela hierarquia, subordinação e dependência do saber médico.

Eu imaginava o meu trabalho, eu, enfermeiro, um técnico de enfermagem, um médico, e que você estaria ali executando 
demanda que o médico te passasse. Não você estar tomando a frente, tomando conta de tudo aquilo, né? (Participante 2).

Não, não sabia que ia trabalhar com o profissional indígena. Eu achava que era uma equipe "branca". É... médico, enfermeiro, técnico de enfermagem, motorista branco, tudo branco. Não imaginava que os indígenas teriam essa participação na saúde (Participante 4).

Tal imagem remete ao modelo clínico de atenção caracterizado pela hegemonia da figura do profissional médico, cuja prática está pautada na captura do corpo doente e fragmentado com foco na recuperação individual. O modelo clínico de atenção trouxe implicações tanto para a atuação profissional quanto para a organização do trabalho em saúde. A Divisão Técnica do Trabalho em Saúde é uma marca persistente na organização do trabalho coletivo em saúde, possuindo, dentre outras características, a hierarquização, a padronização e a distribuição de atividades entre os diversos profissionais. Dessa forma o prestador de cuidado atua como um cumpridor de tarefas, sem nenhuma ligação e entendimento sobre a totalidade do processo. Neste contexto, a enfermagem assume um papel de executora de atividades complementares ao ato médico (ALMEIDA et al., 1991; LIMA e ALMEIDA, 1999; PAl et al., 2006; PIRES, 2008).

Além de carregarem as marcas das experiências profissionais prévias, as expectativas e fantasias acerca do trabalho também podem se entendidas como um reflexo da formação acadêmica. Nesse sentido, a comparação com o trabalho no ambiente hospitalar - primeira experiência de trabalho de muitos participantes - foi reiteradamente colocada.

O trabalho em terra indígena não é usual, tratando-se de uma especificidade. Em um grupo composto por profissionais que nunca tiveram uma experiência semelhante, é esperado e compreensível a comparação com o trabalho em outros espaços, independente do campo onde esta experiência tenha acontecido.

No que diz respeito aos indígenas, as colocações traduziram mais que um imaginário, evidenciando as representações que os participantes carregam sobre esses povos, seus costumes e práticas. 
[...] nem pensava esta questão do dinheiro. Mais mesmo o desejo pessoal de cuidar de pessoas mais humildes, de mato, sei lá... A minha expectativa era ainda encontrar pessoas que usam a natureza para viver mesmo (Participante 8).

Eu tinha vontade porque eu via que são pessoas que precisam mesmo, realmente, que estavam sempre agradecidas por você estar ali ajudando (Participante 2).

O profissional carrega e reproduz o pensamento da sociedade na qual está inserido. O ideário do índio puro, inocente, ignorante e que vive em harmonia com a natureza, prevalece no imaginário nacional, impedindo a percepção dos indígenas como povos históricos e autônomos. Trata-se de uma visão estereotipada, estabelecida profundamente desde o período colonial e reforçada historicamente ao longo dos anos. (LIMA, 1995; GOMES, 2012). Ramos (1995) define esta imagem como o "índio hiper-real", muito distanciada da realidade, dos "índios de carne e osso", constituindo um simulacro.

Os conceitos e as imagens sobre estes povos que nos são repassados e reforçados sutilmente, estão na base da construção de nossa compreensão sobre quem são os indígenas, interferindo na forma como nos relacionamos com eles (SILVA, 2013).

No trabalho em saúde isso traz implicações diretas sobre a forma como o profissional se comporta neste contexto, bem como suas atitudes frente às situações como, por exemplo, o maior ou menor respeito e a abertura para a interlocução com os indígenas e com as práticas tradicionais de cuidado e cura.

Para Bertolani e Leite (2009), há um conjunto de representações sociais próprias e consensuais entre alguns profissionais que atuam na saúde indígena. Como exemplo, citam a relação estabelecida entre a forma como os indígenas adoecem e seus modos de vida.

[...] cremos não ser precipitado inferir que as representações sociais do sistema de saúde e da cultura indígenas presentes entre tais profissionais podem ser ancoradas, quer em estereótipos disseminados durante mais de quinhentos anos de contato, quer em concepções ideológicas mais recentes, como aquela que estabelece sumariamente que os índios perderam a sua cultura - ou seja, já não seriam mais índios [...] (BERTOLANI e LEITE, 2009, p.297). 
A respeito dos profissionais de enfermagem, Silva (2014) coloca que a presença constante em campo leva a construção de uma atitude muito particular nesses profissionais, sustentada por um conjunto de percepções sobre os indígenas, seus modos e suas práticas. A autora argumenta que a prática dos profissionais de enfermagem está imbuída de uma lógica tutelar característica deste campo profissional e que compartilha discursos e valores comuns ao discurso sanitarista e indigenista como, por exemplo, a premência de salvar vidas.

Da mesma forma, os profissionais também carregam suas concepções sobre seu trabalho e sua profissão. O trabalho da enfermagem, enquanto prática social historicamente construída, tem suas origens no ato de cuidar dirigido aos pobres e exercido prevalentemente pelas mulheres. Benevolência e doação vocacional estão entre as marcas históricas que remetem às origens da profissão e se fazem presentes na forma como ela é vista socialmente. Isso pode exercer influência sobre o tipo de expectativa do profissional frente a sua atuação e ao seu trabalho (Del CURA e RODRIGUES, 1999; GOMES e OLIVEIRA, 2005a; TREZZA et al., 2008).

As falas de alguns dos participantes sinalizam para uma prática ancorada na benevolência.

Poder ajudar eles de um modo diferente, poder dar uma ajudinha melhor para eles, dar uma saúde mais digna (Participante 1).

Os motivos que levaram estes profissionais a atuarem na saúde indígena, mais que ilustrar a realidade deste campo de trabalho e as particularidades regionais sobre a oferta de emprego e remuneração, sugerem uma relação mais subjetiva entre os participantes e o que este espaço de atuação tem a oferecer para cada um, seja no plano pessoal ou profissional. Foi possível inferir que, além de uma oportunidade de emprego com uma remuneração acima do esperado na região, há outros fatores em jogo. Foge aos objetivos da pesquisa analisar o tipo de relação estabelecida entre esses fatores. No entanto, as colocações dos participantes apontam que ela parece estar mais próxima da interação e da somatória do que da hierarquia. Ou seja, para a maioria dos participantes, o ingresso na saúde indígena parece ser motivado por um conjunto de fatores que se inter-relacionam de forma complementar, cuja 
relevância não pode ser mensurada e deve variar com a história individual de cada um.

Um aspecto importante e comum na motivação para o ingresso neste espaço de trabalho parece ser o atrativo da diferença. Um primeiro contato mesmo que incipiente com a temática indígena, desperta uma curiosidade e um desejo de conhecer mais sobre o novo. A curiosidade de conhecer melhor a diferença vivenciála, enfrentar os possíveis desafios que ela impõe, superando assim os limites profissionais e pessoais, é um ponto em comum entre os participantes. $\mathrm{O}$ atrativo da diferença é o convite ao profissional para vivência da interculturalidade. Cada um leva para essa experiência uma bagagem pessoal onde estão armazenados conhecimentos, valores, expectativas, vontades e convicções que compõe o imaginário particular. Como esse imaginário se encaixa com a realidade que está por vir?

\section{3 - DAS SURPRESAS NO ENCONTRO COM A DIFERENÇA AOS DESAFIOS NA IMERSÃO NO CONTEXTO INTERCULTURAL.}

Foi identificado que todos os participantes seguem um itinerário comum, que se inicia com o impacto das surpresas causadas pelo contato com a realidade do contexto de trabalho durante as primeiras incursões dentro da terra indígena. A partir desse ponto, os profissionais prosseguem em um processo de apropriação e consequente adaptação a esta nova realidade, impulsionada por uma efetiva imersão no contexto de trabalho. Apesar das singularidades, todos parecem traçar um caminho muito semelhante, até mesmo aqueles que já tinham experiência com o trabalho em outras terras indígenas.

A permanência no trabalho parece ser um indicativo de sucesso no processo de adaptação. Apesar disso, mesmo os profissionais que já atuam há bastante tempo, que estão à vontade com o contexto e com 0 trabalho, são tomados por um desconforto permanente, um misto de insegurança, medo e desconfiança, que parece não poder ser suprimido nessa interlocução com o outro. 


\author{
4.3.1 - Surpresas no Contato com a Realidade: Ajustes Entre o \\ Imaginário e o Real.
}

O impactante é isso, você ver a organização social dele dentro de uma aldeia, o cotidiano deles ali, aquele tanto de criança.

(Participante 10)

Os participantes experimentaram distintas formas de inserção no trabalho. Alguns de maneira mais orientada e amparada e outros de forma bastante desordenada, sem recomendações e suporte mínimos. Em comum, todos vivenciaram situações de surpresa provocadas pelo encontro entre o imaginário e o real.

Os participantes trouxeram relatos detalhados sobre as primeiras experiências de trabalho dentro do território indígena, destacando as questões que mais os impactaram neste encontro com o novo e como algumas delas foram decisivas para a permanência no trabalho.

Para a maior parte do grupo, a primeira entrada na terra indígena ocorreu de forma planejada e sob acompanhamento de um enfermeiro mais experiente. No DSEI Xingu, em geral, essa primeira incursão ao território tem duração média de 20 dias e um caráter mais exploratório. Nesta primeira permanência em área, ao mesmo tempo em que foram apresentados ao serviço, os participantes desempenharam atividades sob supervisão e foram avaliados pelos profissionais que os acompanharam, e também pelos indígenas.

Mas, há quem passou por experiência menos sensível, permanecendo 40 dias em área, e quem passou as festas de final de ano dentro do território. Os participantes cinco e nove, que iniciaram a atuação na saúde indígena como técnicos de enfermagem em outro DSEI, também foram inseridos no trabalho dentro de área de forma pouco assistida sem nenhuma orientação prévia ou acompanhamento.

Foi difícil porque você não conhece índio. Naquele momento você não conhecia nada. Me ligaram, era umas duas horas da tarde e disseram: "oh, é para você arrumar as coisas". [...] só me falou que eu tinha que entrar em área, levar as comidas e minhas coisas. Eu arrumei as coisas, saí de noite de Barra do Garças, fui trabalhar no município de Campinápolis. Fiz o percurso praticamente todo à noite, 
sem conhecer nada e cheguei na aldeia umas três horas da manhã. Tudo novo, mato, você não conhecia nada. Aí, no outro dia, você se deparar com aquilo: cultura diferente, outras línguas (Participante 9).

Num balanço final, muitos dos participantes do grupo classificaram a primeira entrada em área indígena como positiva e prazerosa, apesar das dificuldades enfrentadas.

A gente teve na primeira entrada. Naquele momento a gente quase não participou muito do trabalho. Foi mais uma questão para ver, para olhar ver se dava conta. Essa primeira entrada foi muito longa, mas também foi muito difícil. A questão da logística, a questão da distância. Mas, como a gente estava só conhecendo, parecia tudo muito bonito, até o momento que a gente começou a ver as dificuldades que foram aparecendo. [...] Mas foi muito bacana, a primeira entrada foi bacana (Participante10).

Esta experiência do encontro entre o imaginário e o real foi marcada especialmente pela surpresa. Nesse caminho, não surpreende o estranhamento causado pelos hábitos e práticas dos indígenas, em especial aquelas relacionadas à higiene, e à alimentação.

Acho que foi mesmo a questão da família deles, dentro das casas, da alimentação. A primeira coisa que eles me oferecerem foi tracajá e eu não como tracajá. Então foi mais essa coisa mesmo, dos bichinhos que eu cuido, que eu cuidava e eles estavam comendo (Participante 6).

A questão que mais impactou para mim foi a questão da alimentação, a forma como eles comiam, o que eles comiam, a questão da própria higiene do ambiente e você já começa a pensar: "Isso tudo aqui é propício ao adoecimento, tecnicamente pensando" (Participante 11).

Os relatos demonstram que, já de início, o profissional assume a posição de observador participante, lançando seu olhar sobre as situações que presencia ou vivencia. Algumas delas parecem gerar mais incômodo quando julgadas, analisadas e interpretadas sob a sua ótica e sob os valores de seu próprio sistema cultural. A 
participante seis relatou sobre duas situações vivenciadas no início do trabalho e sua interpretação sobre elas:

O que mais me assustou é que a gente dá muita importância para os idosos, para as crianças. O que me espantou na época foi a questão da alimentação. Primeiro chegava, comia o homem. A mulher preparava, o homem da casa comia, depois as crianças, a mulher e, por último, os idosos. Pelo menos lá eles têm esse costume. Isso me chocou bastante (Participante 6).

Lá você percebe em algumas famílias o interesse não em cuidar do velho, mas pegar o dinheiro que vai receber da aposentadoria. No caso dela que não tinha, então, ela era isolada (Participante 6).

Langdon e Wiik (2010, p.177) alertam que "ao se deparar com os costumes presentes em outras culturas, deve-se tentar entender seu porquê. Dessa forma, evita-se a compreensão etnocêntrica a seu respeito [...]". Pereira (2012) entende essa leitura etnocêntrica como resultado da urgência do profissional, muitas vezes despreparado, em traduzir ou interpretar as situações vivenciadas e observadas no encontro com a diferença, utilizando para isso os seus próprios referenciais.

Em oposição a essa postura etnocêntrica, a capacidade de relativizar é apontada como atitude chave para a compreensão e reconhecimento da diferença, necessária ao alcance de relações mais respeitosas e menos conflituosas (ARRUDA, 2015; LANGDON e WIIK, 2010; MENDONÇA, 2010).

De forma curiosa, alguns participantes também relataram que, neste primeiro contato com o território, ficaram positivamente surpresos com a receptividade dos indígenas, marcada pela cordialidade, simpatia e acolhida. Para o participante nove, a boa acolhida dos indígenas foi determinante para que prosseguisse no trabalho, mesmo após ter vivenciado experiências negativas anteriormente.

Acho que um fator que fez eu continuar a trabalhar até hoje com os indígenas foi essa aldeia que eu fui. Indígenas atenciosos, a recepção lá foi muito boa, lá (DSEI Xavante) era bem tranquilo, eles foram me ensinando, eu fui aprendendo muitas coisas. Eu gostava. O período que eu chegava lá para trabalhar, eu me sentia bem (Participante 9). 
A recepção que eles têm com a gente, se preocupam como você está, se está precisando de alguma coisa, como está a sua família. Então, a receptividade aqui (DSEI Xingu) deles foi muito boa. É o que dá mais ânimo para gente trabalhar, mais ainda com eles aqui (Participante 9).

A estrutura para o trabalho $e$ as acomodações surpreenderam a muitos que esperavam encontrar um cenário menos organizado. Esse foi o caso dos profissionais que realizaram a primeira entrada de trabalho nos Polos Base onde, em geral, a estrutura é melhor. Para outros, como a participante seis, que iniciou o trabalho em um dos pontos de apoio, ficou a marca das dificuldades enfrentadas com a falta de estrutura.

Aí que senti esse baque por causa da questão de estrutura mesmo. A UBS ser junto com a casa do profissional, cheguei lá só tinha uns banquinhos, não tinha mesa na casa do profissional, não tinha nada (Participante 6).

A adaptação às novas condições de moradia e de alimentação foi relatada pela maior parte do grupo como tranquila, porém, não o suficiente para suprimir a tristeza causada pelo isolamento e pelo distanciamento da família.

No que diz respeito ao trabalho da Equipe Multidisciplinar de Saúde Indígena, um fato, digno de surpresa e de admiração, muito colocado pelos participantes, foi a presença e a atuação dos profissionais indígenas de saúde. Estes profissionais de saúde não fazem parte do imaginário elaborado sobre o campo, uma vez que a maior parte dos participantes desconhecia a existência desses profissionais. Os demais, apesar de conhecerem e até terem tido contato prévio com profissionais indígenas de saúde, ignoravam a dimensão efetiva de seu papel e de sua atuação. Com o desempenho de tarefas consideradas mais simples e rotineiras até as mais complexas tecnicamente, a atuação dos AIS e AEI causa surpresa e admiração. Dentre as características da atuação dos profissionais indígenas de saúde que mais chamaram atenção, destacam-se o desempenho técnico, o conhecimento sobre as práticas da biomedicina, o domínio sobre o processo de trabalho e as ações do cotidiano bem como o protagonismo dentro da equipe. 
Foi bem diferente, porque quando eu cheguei aqui me falaram que tinha o auxiliar de enfermagem, tinha a formação dos AIS, que eu não sabia que eles já estavam nessa... como posso dizer... nesse nível de instrução. De ser um AIS, um auxiliar de enfermagem. Porque aqui o auxiliar de enfermagem faz coisas que até eu mesma não fazia, e ele tinha o conhecimento. Isso também eu achei bem interessante deles. Também chamou muita atenção (Participante 2).

Na verdade, eu fiquei foi admirada com os AIS principalmente, a capacidade que eles têm, a experiência que eles têm também aqui dentro (Participante 3).

O grau de conhecimento dos indígenas chega a representar, em alguns momentos, uma ameaça. O profissional se sente testado ou cria uma desconfiança acerca do comportamento dos indígenas.

Agora, existe uma outra realidade, que é o real do trabalho do enfermeiro que é a questão da pressão. Existe uma pressão, porque eles (profissionais indígenas) aprenderam muitas coisas aqui (participante 8).

Algumas falas sugerem que a surpresa vem acompanhada da subestimação sobre a capacidade dos indígenas. A falta de reconhecimento e a desqualificação da atuação dos profissionais indígenas, em especial o AIS, figura entre os conflitos mais comuns presentes na relação entre estes e os demais integrantes das EMSI (LANGDON et al., 2006; NOVO, 2009).

E uma das outras coisas que eu me senti muito admirado com eles, com os profissionais indígenas, foi a questão do horário de medicamentos. Eu não sabia, eu nunca tinha visto isso, os próprios índios darem a medicação. Eu não achava que era assim. Isso foi uma das coisas que eu mais me surpreendi aqui também (Participante 7).

Mas, foi uma surpresa boa também saber que eles têm capacidade, que eles podem ajudar a gente, eles podem ensinar a gente, até pela experiência... e isso foi uma surpresa bem gratificante, boa (Participante 4). 
No PIX, as experiências de formação de profissionais indígenas foram desenvolvidas pela UNIFESP atendendo às diretrizes apontadas pelo Ministério da Saúde e, ao mesmo tempo, voltadas para a realidade local. Dessa forma, a formação desses profissionais efetivou-se de forma muito particular, com ares artesanais e aspectos bastante distintos das demais experiências no restante do país. O objetivo foi formar profissionais indígenas capazes de intervir de forma competente sobre os problemas de saúde no contexto de sua realidade sociocultural reconhecendo a importância de seu papel na efetivação do princípio da atenção diferenciada (MENDONÇA, 2005; OLIVEIRA, 2005a; RECH, 2008). O protagonismo dos indígenas também foi permanentemente valorizado pela UNIFESP.

Como reflexo disso, a participação e a atuação dos profissionais indígenas integrando as equipes multidisciplinares sempre foi bastante expressiva. Somado a isso, semelhante ao que ocorre em outros territórios indígenas no país, nos períodos de ausência dos demais profissionais da equipe e em aldeias de mais difícil acesso, com frequência são os profissionais indígenas que assumem a maior parte das atividades de saúde em suas comunidades (DIEHL et al., 2012). No PIX este é um dos motivos que colaboram com a maior participação dos profissionais indígenas no trabalho.

Ainda sobre o trabalho da EMSI, a atuação do enfermeiro é apontada pelos participantes como a maior das surpresas, um dos pontos mais marcantes nesse contato com a realidade do trabalho. Os novos profissionais se depararam com enfermeiros assumindo um papel central no gerenciamento da equipe, desenvolvendo diversas atividades e, muitas vezes, atuando de forma solitária. Um perfil de atuação muito diferente do que já havia sido vivenciado por todos eles.

E quando eu vi a enfermeira que estava aqui no atendimento, eu fiquei um pouco assustada porque ela estava só e ela tinha que fazer o atendimento, dar um possível diagnóstico. Avaliar e dar um diagnóstico. [...] Aquilo me assustou. Porque dentro do hospital é diferente. Ali eu só mexia com papéis. E quando eu vi ela sozinha com esse tanto de gente eu me assustei (Participante 2).

Na verdade também as várias coisas que são feitas aqui dentro de área, não tem nada a ver com o que o enfermeiro pode fazer na cidade. Isso me deixou bastante assustada no primeiro impacto. Meu primeiro impacto quando eu cheguei e que me falaram que eu tinha 
que fazer parto, que eu tinha que fazer sutura. Então, com isso eu fiquei bastante assustada na verdade (Participante 3).

O que mais marcou foi a dificuldade que estava no Pavuru, naquele momento estava o $D$. (enfermeiro) sozinho aqui e quando a gente chegou aqui, foi o lugar onde a gente mais sentiu medo. Porque estava uma demanda muito grande e a UBS lotada, o $D$. sozinho aqui. De toda a viagem, o que mais marcou foi isso. Quando a gente chegou aqui, nossa! E daí já estava meio certo que eu viria para cá. Então eu pensei: "Nossa, onde é que eu fui parar" (Participante 10).

Foi possível concluir que o primeiro contato com o trabalho dentro da área indígena constitui efetivamente uma experiência bastante impactante para os profissionais, tornando-se um dos marcos da experiência de trabalho neste campo. O caráter exploratório da primeira entrada parece garantir um determinado conforto. Essa primeira incursão ao território permitiu aos profissionais conhecerem um pouco mais sobre as características do trabalho e consistindo também uma oportunidade de experimentar, mesmo que de forma breve e superficial, a permanência dentro da área indígena. Neste momento, todos vivenciaram situações diversas sendo algumas bastante positivas, de encantamento, e outras, reveladoras da realidade de trabalho e das dificuldades que estavam por vir. Em sua primeira entrada, a participante oito experimentou o desconforto e a insegurança causados pela convivência em grupo e pelo contato com os indígenas.

Foi um baque, porque era muito tempo junto com aquelas pessoas diferentes, em um ambiente diferente, aquela expectativa, o medo de estar sendo observada por todos, não só pelos colegas também, mas pelos indígenas (Participante 8).

Para muitos deles, este primeiro contato foi o suficiente para se questionarem sobre retornar ou não. Entretanto, todos os profissionais retornaram. Interrogar sobre os motivos que fizeram com que esses profissionais assumissem o trabalho torna-se relevante. Porque esses profissionais assumiram o trabalho?

Os participantes três e dez relataram o quanto se sentiram assustados com 0 contexto e o quanto se sentiram inaptos para o trabalho. Quando questionados sobre o porque retornaram, ambos apontaram a boa acolhida dos indígenas e a ajuda dos outros profissionais da equipe como motivadores para a permanência. 
Quando eu entrei, por exemplo, não tinha gerador em área, não tinha água, nada. Tudo era uma outra realidade eu nunca tinha passado por isso lá fora, ter que ir para o rio, todos os dias sem energia. Então pra mim, isso, eu achei que eu ia sair para a folga e não voltaria mais para área (Participante 3).

Na colocação do participante nove, a permanência em área parece figurar como um refúgio de problemas vivenciados no meio urbano.

Então, assim... eu tinha os meus problemas extras na cidade e lá era um lugar que me fazia esquecer essas coisas. Ás vezes eu pegava folga, mas eu tinha vontade já de estar voltando. E a amizade. As equipes que naquele tempo trabalhavam com a gente. Nós éramos praticamente irmãos mesmo, de verdade. Aquela coisa, aquela harmonia, trabalhava todo mundo junto. Aquilo lá favorecia a gente. As equipes que trabalhavam lá, os profissionais da saúde indígena lá, trabalhavam bastante. O próprio respeito da comunidade com você, as crianças. O fator primordial para mim hoje são as crianças indígenas e os idosos que eu gosto (Participante 9).

\subsection{2 - A Imersão na Área Indígena}

A partir dessa primeira aproximação, os profissionais passam a experimentar o trabalho e, à medida que prosseguem com a experiência, vão se apropriando do contexto e de suas demandas num percurso bastante particular. Pouco a pouco, a vivência da interculturalidade vai se colocando de forma mais clara e expressiva.

Os participantes descreveram o início do trabalho como uma fase difícil, marcada pelo enfrentamento de muitas dificuldades.

Dificuldade de comunicação, de entendimento com o indígena, essa questão espiritual da pajelança, saber respeitar o momento deles, da questão de falta de estrutura da UBS, materiais, medicamentos. Da questão também de logística, tudo, que envolve a retirada de voo, solicitação de voo, questão burocrática relacionada a isso. Seriam mais estas dificuldades de primeiro momento, que a gente teve mais dificuldade para enfrentar (Participante 10). 
Todos apontaram a dificuldade com as demandas técnicas como um ponto marcante deste momento. Para muitos deles, tais dificuldades superaram as dificuldades pessoais $^{16}$.

Eu fui identificando minhas dificuldades nas minhas avaliações do exame físico mesmo. Avaliação de uma ausculta pulmonar que eu tinha só a teoria, eu não tinha a prática. Foi a avaliação física mesmo (Participante 2).

Eu nunca me imaginava ajudando em um parto, fazendo uma sutura (Participante 2).

As falas são reveladoras em sinalizar que as dificuldades técnicas se sobressaem às demandas colocadas pelo trabalho em um contexto tão particular em termos de língua, ambiente, cultura e estrutura. Alguns participantes chegaram a colocar que essas dificuldades quase não existiram ou foram superadas com muita facilidade. Não faltaram afirmações sobre uma adaptação rápida, fácil ou tranquila às novas características do ambiente e à cultura, fruto da ajuda ofertada pelos profissionais mais experientes e também pelos indígenas, cumprindo o papel de apresentar o contexto aos novatos.

A relação com os indígenas não foi colocada de forma clara e alguns participantes relataram não terem enfrentado dificuldades a esse respeito. $\mathrm{Na}$ fala de alguns deles, o sucesso da relação está associado ao tipo de vínculo estabelecido como os indígenas, que deve ser pautado na confiança, termo presente nas colocações de seis dos onze participantes.

\footnotetext{
${ }^{16}$ Durante as entrevistas, para uma melhor compreensão e maior facilidade de abordagem aos participantes, as dificuldades enfrentadas na experiência do trabalho foram classificadas como "profissionais" e "pessoais". As primeiras correspondem às dificuldades enfrentadas com o desempenho profissional, especialmente o desempenho técnico e a realização de atividades de saúde. Como dificuldades pessoais foram consideradas aquelas relacionadas à permanência em um ambiente diferente, características geográficas, condições de moradia, convivência intensa e direta com os indígenas e com os outros profissionais da equipe.
} 
Então foi mais uma questão no início de ter a confiança deles e eles a minha, conseguir se relacionar, ter essa confiança mútua um no outro. De primeiro momento foi isso mesmo, depois a gente não teve mais tanta dificuldade (Participante 10).

O tempo todo a gente vê uma desconfiança. Uma desconfiança muito grande. Par eles conseguirem confiar na gente, a gente tem que ter um trabalho assim bem devagar (participante 8).

Uma característica importante do trabalho dentro de área no DSEI Xingu é a imersão vivida pelos profissionais. Pouco a pouco o profissional vai experimentando uma imersão no contexto de trabalho, um mergulho em águas pouco conhecidas.

Os participantes relataram uma rotina diária em que todas as ações são permeadas em maior ou menor grau pela atuação profissional, tornando-se difícil estabelecer os limites temporais e espaciais do trabalho. É possível delimitar o que é trabalho nesse contexto? Em que momento o profissional se vê trabalhado e em que momento não? Dessa forma, os longos períodos dentro de área além de intensificarem a vivência da relação intercultural estão associados ao cansaço físico e ao desgaste emocional.

Porque a gente está longe da nossa realidade, da família, dos amigos, das coisas que te dão prazer, eu falo das coisas materiais. $E$ isso te desgasta um pouco, né? Você está introduzido dentro da realidade deles e aí você abdica um pouco de você para viver esta realidade. A gente passa por muitas privações e, particularmente, eu vejo que a vida da gente fica, a gente fica vivendo a vida deles e a nossa vida fica um pouco parada no tempo (Participante 4).

Se, num primeiro momento, as dificuldades com a dimensão técnica parecem se sobressair na vivência do trabalho de campo, aos poucos, outras questões vão emergindo e se impondo no cotidiano do trabalho. Algumas dificuldades estão relacionadas diretamente à interculturalidade: língua, hábitos alimentares, etiquetas no trato do dia a dia e relação com os indígenas.

A cultura tem uma outra coisa também que foi muito difícil para mim no começo, duas experiências que eu posso dizer que, para mim, foi difícil, que me abalaram no começo e aquela dúvida se eu ia 
conseguir ficar aqui ou não. Era a questão do uso da água, que a hidratação deles é muito restrita, então eu era a enfermeira da água aqui. Chegava na minha consulta, eu falava de água e já viravam os olhinhos e começavam a falar na língua dando bronca em mim. E a outra experiência foi quando eu estava fazendo um curativo numa criança que machucou. No segundo dia que ela foi fazer o curativo, ela estava toda suja de barro e tinha que fazer o curativo com ela toda suja de barro de manhã cedinho. E aí eu peguei a criança no colo do pai, fui lá, lavei a perna debaixo da torneira e foi a maior ofensa que eu fiz (Participante 8).

Até mesmo as características pessoais entram em jogo nesta relação com os indígenas:

\begin{abstract}
Agora mesmo a minha maior dificuldade é com o meu jeito, que também eles (indígenas) cobram muito. E eu estou tentando mudar este jeito. O meu jeito fechado, calada, eu não brinco, não estou sorrindo. Eles falam que eu fico triste. Mas é meu jeito mesmo de ser. Calada e quieta num canto. E eles acham que eu não estou bem aqui. E não é isso. É porque é o meu jeito (Participante 2).
\end{abstract}

Em qualquer lugar, a vida, o comportamento das pessoas pode ir mudando. Mas você tem a sua vida pessoal também, um jeito de ser seu no meio de um lugar que é diferente. Para mim, no começo pessoalmente foi difícil (Participante 8).

Somado a isso, há outras questões adjacentes, colocadas pela organização do trabalho dentro da terra indígena, que são também muito significativas nesta vivência. Concordando com o que foi colocado por Louzada e Neto (2010), além do isolamento e distanciamento da família já colocados anteriormente, a falta de privacidade, o cansaço físico, e a intensidade das relações interpessoais também foram citadas pelo grupo como fontes de desgaste emocional, trazendo implicações para a atuação profissional.

A participante oito colocou suas dificuldades com a falta de privacidade e citou estratégias elaboradas para enfrentá-las.

Em dezembro que eu fiquei mais sozinha, sozinha mesmo, estava sem água aqui no polo, estava muito cansativo. Então eu falava: "Da licença que eu preciso descansar". Tinha vezes eu tinha que ficar até 
mais tarde na UBS, para não vir mais cedo para casa para não entrarem aqui (Participante 8).

Neste ponto, merece destaque as relações interpessoais entre os integrantes da equipe, uma questão recorrentemente colocada nas falas. Inúmeras vezes os participantes citaram as dificuldades advindas da convivência intensa e prolongada entre os profissionais da equipe. Autocontrole, paciência e cautela foram apontados como necessários para a convivência diária menos conflituosa, principalmente no trato com aqueles profissionais que têm personalidade forte.

Outra dificuldade é estar com outros profissionais, trabalhar junto. Trabalhar junto, morar junto, executar tudo junto. Fica trinta dias ao lado de uma pessoa que é só um colega de trabalho, mas, na mesma hora ele é um colega seu pessoal, se torna mesmo que você não queira. Mas ele vira um colega seu pessoal, vira um confidente, vira sua família. Sua família se torna este profissional que está com você (Participante 4).

Porque não é fácil, conviver com uma pessoa o dia inteiro no trabalho, em casa. Aqui a gente convive vinte e quatro horas por dia. Então não é fácil ainda mais que ninguém é igual e tem pessoas com a personalidade muito forte. Tem que aprender a lidar com elas também (Participante 6).

As dificuldades e conflitos interpessoais são esperados no trabalho em equipe, sendo natural que, em um contexto como o do PIX onde trabalho e vida se tornam indissociáveis, eles se tornem mais presentes. No caso em questão, os conflitos também podem ser entendidos como um reflexo do aumento expressivo do número de profissionais das EMSI a partir de 2010. O incremento no número de profissionais nas equipes implica também em maior diversidade de personalidades, experiências, capacidades técnicas e envolvimento com o trabalho. A EMSI se concretiza como um espaço relacional, que abriga distintas formas de relação com o trabalho e todo o seu contexto.

Independente da origem dos conflitos e a esfera onde eles ocorrem, a longa permanência em área não pode ser desconsiderada como sendo um fator de peso importante na forma como o profissional vivencia o trabalho. 
Todos os participantes relataram insatisfação com a escala de trabalho que implica em períodos de, aproximadamente, 28 dias dentro da terra indígena. A última semana dentro de área é descrita como um período pouco produtivo, em que o profissional não rende mais. Apesar da insatisfação, não há um consenso sobre uma escala de trabalho ideal. Para os profissionais que atuam em abrangências maiores, com grande número de aldeias e longas distâncias a serem percorridas, a escala de trinta dias é vista como necessária, apesar de cansativa.

Porque quando chega a terceira semana... É muito tempo, porque você acaba perdendo todo o trabalho que você fez nas três semanas em uma semana só (Participante 3).

São trinta dias, vinte e quatro horas, porque qualquer hora que eles precisarem, você tem que estar à disposição. Você tem que ajudar, você tem que estar bem, você não pode reclamar. Então a gente tem que saber lidar com isso (Participante 2).

Eu sou do ponto de vista que o profissional, quando passa do vigésimo dia, o rendimento dele não é bom, a tendência é cair. Se mudasse a escala dos profissionais, com certeza todos trabalhariam com mais prazer, o rendimento seria muito melhor. Essa é a minha opinião (Participante 9).

Foi identificado que, com o passar do tempo, algumas situações e questões consideradas de fácil enfrentamento ganham outro peso. Após alguns anos de trabalho, o esforço aplicado no enfrentamento dos problemas passa a ser sentido como um sacrifício, e a longa permanência dentro de área parece tornar-se inviável. As colocações da participante oito indicam possivelmente um ponto de saturação. Após pouco mais de dois anos trabalhando em área, as estratégias elaboradas por essa profissional para garantir a permanência nesse contexto, parecem não serem mais suficientes, sinalizando que o tempo de trabalho dentro de área já se esgotou.

A gente precisa ultrapassar o nosso limite físico e psicológico aqui dentro. Ás vezes, eu tenho que fazer, muitas vezes, sacrifício físico (Participante 8). 
O que faz o profissional prosseguir com o trabalho? Quando interrogada sobre o porquê da permanência no trabalho, a participante oito ressaltou a satisfação com o trabalho, a importância de sua atuação e de sentir-se valorizada.

Porque eu fico com saudade. A gente reclama, né? Mas, eu gosto muito. Eu gosto demais daqui. [...] Você fica pensando assim: "você está aqui, essas pessoas precisam de você." Pensar que as pessoas gostam de mim. E eu sei que tem muita coisa que eu consegui fazer a diferença aqui. Isso me faz continuar, me sinto satisfeita, realizada profissionalmente e valorizada (Participante 8).

Da mesma forma, com o tempo, também passam a ganhar destaque as situações difíceis, com desfechos ruins. As situações de conflito estão invariavelmente relacionadas ao trabalho e, em geral, se dão nas situações de urgência e emergência, tendo como pano de fundo a interculturalidade.

Os profissionais parecem seguir um trajeto rumo a um estado de acomodação ao contexto $^{17}$. À medida que se acomoda, o profissional vai se distanciando do estranhamento inicial e sente-se mais confortável no contexto em que está inserido.

Algumas falas, sugerem, no entanto, que essa acomodação, não se traduz em uma adaptação plena, livre de tensão. Pelo contrário, é possível inferir que o contexto se caracteriza por uma tensão latente. A memória das situações conflituosas e de maior tensão vivenciadas pelos profissionais parecem contribuir com isso.

O participante nove enfatizou em sua fala a preocupação em trabalhar da forma correta. Tal postura parece ser reflexo das experiências que vivenciou durante trabalho em campo e na CASAI, enquanto atuou no DSEI Xavante.

Mas muitas coisas que não existiam no período que eu trabalhava em área indígena (DSEI Xavante), hoje mudou bastante. Quando eu vim para cá (DSEI Xingu) eu já sabia o risco, o risco não, eu já sabia o que poderia acontecer, as coisas que a gente tem que estar fazendo, sempre trabalhar do modo correto para não ter fofoca $e$ cobranças. [...] Então eu cheguei e "Opa! Sempre estar fazendo correto para não ter nenhum problema." Eu tento fazer o máximo, não ter dúvida, fazer o correto para não ter problema. [...] A questão

${ }^{17}$ O termo acomodação é utilizado aqui com o sentido de adaptar-se, sentir-se confortável. 
do preenchimento de planilhas, estas coisas, a gente sempre estuda, tenta melhorar para não ter problema, não ter cobrança. (Participante 9).

A preocupação com o agir corretamente parece não se restringir à parte técnica, havendo uma preocupação com o comportamento, em atuar de acordo com o que os indígenas e os gestores consideram bom.

\section{4 - RUPTURAS, PERMANÊNCIAS E NOVAS CONSTRUÇÕES: CONCEPÇÕES DOS PROFISSIONAIS A PARTIR DA EXPERIÊNCIA.}

Da mesma forma que os participantes trouxeram consigo concepções acerca do que iriam encontrar no momento da inserção no trabalho, eles também fizeram colocações que evidenciaram as concepções elaboradas a partir da vivência. Não faltaram colocações apontando características e definições sobre o trabalho, sobre o papel do enfermeiro e sobre os indígenas.

Os conteúdos sugerem que o entendimento sobre o trabalho dentro da terra indígena e sobre a atuação do enfermeiro neste contexto sofrem modificações, num processo contínuo de elaboração e reelaboração. Novas compreensões e novas explicações vão sendo elaboradas a partir da releitura do contexto, fundamentadas agora sob um outro ponto de vista, o da vivência, da imersão. Permanências, rupturas e novas construções delineiam uma realidade um pouco mais ou um pouco menos distante do imaginário inicial. As concepções sobre os indígenas também são fruto dessa proximidade e interlocução, promovidos pela imersão na área indígena. 


\subsection{1 - O Trabalho Dentro de Área e a Atuação dos Enfermeiros}

O trabalho aqui é diferente, é diferente de qualquer lugar.

(Participante 10)

O trabalho dentro da área indígena é definido pelos participantes como diferente, difícil e que exige dos profissionais um conjunto de habilidades técnicas e pessoais consideradas indispensáveis.

Uma colocação muito presente nas falas foi sobre a impossibilidade de se trabalhar sozinho. O trabalho em equipe foi apontado por vários profissionais como um ponto essencial para o sucesso e alcance dos objetivos.

O trabalho em equipe hoje é fundamental, não só com os brancos, mas com os indígenas também. Isso é o primordial daqui. Se você conseguir trabalhar em equipe aqui, vai se dar bem (Participante 7).

Pelo conteúdo de algumas falas foi possível identificar que a convivência em grupo se confunde com o trabalho em equipe. O que, muitas vezes, foi mencionado pelos participantes como trabalho em equipe, se referia, na verdade, à convivência em grupo.

Primeiro, o trabalho em equipe é tudo. Se você não estiver trabalhando em equipe o serviço não flui, o serviço não anda. Se não trabalhar em equipe não vai, não anda, não flui. A gente fica aqui o tempo todo, praticamente, a casa nossa é aqui. A primeira aqui e a segunda lá com sua família. Então, o fator primordial é a equipe, união, um ouvir o outro. Vai ter aqueles momentos que pode acontecer alguma coisa, mas trabalho em equipe é tudo (Participante 9).

Segundo Ciamponi e Peduzzi (2000, p.144), há uma concepção do senso comum "onde a equipe é representada como o conjunto de profissionais que realizam um trabalho comum". Nessa perspectiva, o trabalho em equipe fica simplificado a um agrupamento de agentes.

Mais do que isso, o trabalho em equipe se constrói na relação intrínseca entre trabalho e interação. Implica na integração de saberes e na interação dos 
profissionais, impondo a necessidade de relacionamentos interpessoais saudáveis que satisfaçam as necessidades de comunicação, interação e articulação necessárias ao desenvolvimento do trabalho (PEDUZZI, 2001).

Foge aos objetivos da pesquisa analisar o tipo de interação que prevalece entre os profissionais das equipes de campo. Contudo, é possível afirmar que as relações interpessoais entre os profissionais da equipe são muito determinadas pelas particularidades do trabalho dentro de área, sendo fortemente impactadas pela longa permanência no território. Isso precisa ser considerado como fator importante na determinação da atuação dos profissionais e do trabalho.

Um participante relatou sobre a melhor relação entre os integrantes da equipe da qual faz parte em virtude de vínculos de amizade entre os profissionais, anteriores ao trabalho.

\begin{abstract}
Eu acho que a gente enfrentou menos problemas que os outros (polos base) porque eu e o D., a gente já era colega, a gente era amigo, já se conhecia. A gente já tinha um vínculo de amizade de muito tempo. Isso facilita né? A gente tem mais intimidade para perguntar, tirar dúvida, trocar ideia, e a questão da personalidade de cada um mesmo (Participante 10).
\end{abstract}

Como integrantes das Equipes Multidisciplinares de Saúde Indígena, os profissionais indígenas, especialmente os AIS, são reconhecidos como tendo atuação indispensável, sem a qual o trabalho não pode ser desenvolvido.

Sem eles, é praticamente impossível. É impossível você exercer um trabalho aqui no Xingu sem a ajuda de um profissional indígena. $\mathrm{Na}$ minha opinião, na minha avaliação, é praticamente impossível já por todas essas questões. Você ser de um outro lugar, a questão cultural envolvida, a questão deles não confiarem num primeiro momento em você. Muitos, até hoje preferem contar alguma coisa para o AIS e o AIS vem trazer para a gente. Ele é um profissional chave da saúde indígena (Participante 10).

Sobre a atuação no Xingu, os participantes a classificam como uma prática bastante solitária e, ao mesmo tempo, multifacetada. Solidão e responsabilidade foram 
expressões muito utilizadas pelos participantes ao se referirem ao trabalho em área. A figura que emerge é a do enfermeiro sozinho, à frente do trabalho da equipe e assumindo muitas responsabilidades.

Eu sabia que eu tinha que seguir uma rotina no trabalho, mas, as atribuições do enfermeiro na saúde indígena eu fui aprendendo com a rotina, vindo mesmo, pegando no grosso. Ainda é muito confuso. Se faz muitas coisas, muitas coisas mesmo, ao mesmo tempo (participante 8).

As falas do grupo apontam para o desenho de um perfil de atuação onde se fundem características profissionais e pessoais, compondo as dimensões do ser e do fazer profissional. Dinamismo, proatividade e disponibilidade para aprender são citadas como atitudes essenciais ao enfermeiro para o trabalho no campo. A importância da competência técnica é uma unanimidade no grupo.

Dentro da saúde indígena você tem que ser dinâmico, ser maleável nas situações, tentar trabalhar com as ferramentas que você tem. Isso eu aprendi com uma enfermeira da saúde indígena lá no Xavante. Você tem que ser dinâmico, tem que criar uma situação, criar um cenário (Participante 5).

O participante dez resume o perfil profissional com base em três componentes essenciais:

[...] Aqui são várias questões. Não adianta você ser bom tecnicamente, se você tem uma personalidade difícil de trabalhar com a equipe e com os indígenas. Então, aqui, são três coisas fundamentais: você ser bom tecnicamente, claro, você saber trabalhar em equipe e você saber trabalhar com indígena (Participante 10).

Diálogo, escuta, capacidade de ponderar e renunciar às próprias ideias frente a uma variedade de opiniões são posturas pessoais que garantem uma melhor convivência entre o grupo e entre a equipe, e minimizando os conflitos. Para o participante oito, a intensidade das relações interpessoais provocada pela imersão, 
parece ser tão desafiadora, em alguns momentos, quanto as outras demandas colocadas pelo contexto do trabalho.

Pode ser um excelente profissional, mas a questão pessoal... você fazer comida, lavar banheiro, lavar roupa, relação interpessoal com uma pessoa que você não conhece, nunca viu. Às vezes, é muito mais sofrivel do que o desconhecimento que ela tem na saúde, na parte profissional (Participante 8).

A atuação do enfermeiro dentro das áreas indígenas é definida, em grande parte, pelas características do trabalho. Dispersão geográfica, difícil acesso a algumas aldeias, pouca oferta de profissionais médicos e falta de estrutura são fatores que se somam e colaboram para o desenho do perfil de atuação desse profissional. A competência técnica é exigida frente à necessidade de conhecimento e manejo adequado dos principais problemas de saúde que acometem as populações indígenas, em especial aqueles que respondem pelos elevados índices de mortalidade nestas populações, como, por exemplo, as infeções respiratórias nas crianças. As principais dificuldades enfrentadas pelos participantes estão relacionadas à atenção à saúde materno infantil: pré-natal, assistência ao parto e às crianças menores de cinco anos.

Duas outras características bastante apontadas no grupo para descrever a atuação do enfermeiro foram responsabilidade e a maior autonomia profissional.

A responsabilidade foi associada ao papel de destaque do enfermeiro estando à frente do trabalho da equipe. A organização do trabalho no Xingu coloca o enfermeiro em posição centralizada. No Xingu, a centralidade do enfermeiro deriva de um vasto repertório de atividades assistenciais e gerenciais que estão sob sua responsabilidade, diferente da centralidade do profissional médico característica do modelo clínico, caracterizada por um papel bastante definido e ancorado no saber Diferente da centralidade do profissional médico característica do modelo clínico, caracterizada por um papel bastante definido e ancorado no saber científico. Isso inclui o desenvolvimento de atividades para as quais os enfermeiros não foram preparados ou para as quais não estão respaldados legalmente. 
As falas sugerem que, para os participantes, o desempenho de atividades que normalmente não são realizadas pelos enfermeiros em outros espaços de trabalho, fugindo dos limites legais da profissão, é entendido como autonomia.

A autonomia do enfermeiro em área é bem diferente da cidade. Como eu te falei, prescrever medicamento é uma coisa que a gente não faz na cidade. Sutura, parto, essas coisas assim (Participante 3).

Dentro da saúde indígena, a autonomia que a gente tem, a confiança deles também, que eles depositam na gente. Quando eu entrei tinha muita dificuldade nessa questão de não ter sempre a presença da figura do médico (Participante 4).

A autonomia técnica pode ser entendida como capacidade que o profissional tem de tomar decisões baseadas em conhecimento, valores éticos e experiência, responsabilizando-se pelos resultados obtidos. Na enfermagem, a autonomia é a capacidade do enfermeiro de cumprir suas funções profissionais de forma auto determinada, com liberdade para tomada de decisão frente às necessidades de saúde, respeitando os aspectos legais, éticos e técnicos da profissão. 0 conhecimento é a base para a tomada de decisões. Em um trabalho em equipe, a autonomia técnica dos enfermeiros é relativa e seus limites estão inscritos nos saberes e competências dos demais profissionais, na organização do trabalho e na filosofia institucional (PEDUZZI, 2001; GOMES e OLIVERIA, 2005a, 2005b; MARQUES e LIMA, 2008; DIAS, 2009; PIRES, 2008; PRZENYCZKA et al., 2012; BELLAGUARDA et al., 2013).

Nesse sentido, o entendimento da autonomia como a simples realização de um repertório de procedimentos técnicos é um equívoco e se torna mais preocupante quando tais práticas são desempenhadas sem os conhecimentos e as habilidades necessárias para tal, ou estão fora dos limites legais da profissão.

Segundo Rocha (2007) e Fernandes (2010), é comum que o desempenho de atividades para as quais não foram preparados passe a ser naturalizado pelos enfermeiros e considerado "aceitável" para o trabalho em área indígena.

No Xingu o mesmo perfil de atuação que traz aos profissionais a impressão de uma atuação mais autônoma é também fonte de ansiedade uma vez que os enfermeiros 
reconhecem o despreparo para o desempenho de tais atividades e expressam medo e insegurança. Nesse caminho, a identidade profissional também parece ficar perdida, e a comparação da atuação do enfermeiro com a de outros profissionais, em especial o médico, é recorrente nas falas dos participantes.

Porque eu cheguei lá e me vi como enfermeira, como dentista, como médica, e isso eu não imaginava. [...] Foi onde eu me peguei várias vezes em apuros. "Putz, eu tô fazendo papel de médico aqui" era uma coisa que eu não podia estar fazendo (Participante 6).

Porque você não é só enfermeiro. Você é psicólogo, é médico. O médico fica quinze dias em área e quinze dias fora. Mas, num polo desse tamanho, às vezes, você fica muito, muito pouco tempo com o médico. Então, se você não tiver plena convicção do que você está fazendo, não tiver certeza, é muito complicado essa parte (Participante 7).

Mas eu não achava que a gente tinha que fazer tudo isso que agente faz aqui em área, tipo... um atendimento quase igual ao médico na verdade (Participante 3).

O participante onze considera que o perfil de atuação do enfermeiro dentro de área o afasta de sua profissão.

Porque se você tem um médico em área, você pode atuar mais como enfermeiro e deixar toda aquela demanda clínica para ele. Eu acho que o enfermeiro se ocupa muito com clínica lá dentro, clínica, clínica, clínica e clínica! E ele esquece do trabalho dele como profissional de enfermagem (Participante 11).

Amor e abdicação também foram citados entre os valores e as atitudes necessárias à atuação dos profissionais que se propõem a trabalhar dentro de área, atendendo a uma expectativa dos próprios indígenas.

Além de você ser um bom profissional, você tem que ser uma pessoa humana. E eles gostam de ser tratados bem, eles gostam de sentir a sua preocupação quanto a eles e eles querem que o profissional que esteja aqui tenha amor pelo que faz. Os indígenas te vem como uma pessoa que está lá para fazer o bem, eles não te veem como uma pessoa que está lá por estar. Eles te veem como uma pessoa que 
está lá para ajudar, que vai ajudar a família dele a não adoecer, a família dele não morrer (Participante 4).

Tais afirmações apontam para uma visão sobre o profissional e seu papel moldada sob o estereótipo da caridade. Assim, parecem apenas reforçar velhas concepções e explicitar a força dos estereótipos e das representações sociais sobre a profissão.

O panorama elaborado pelos participantes desta pesquisa sobre $\mathrm{o}$ trabalho e a atuação do enfermeiro guardam semelhanças com o que foi encontrado por Rech em estudo envolvendo enfermeiros no Parque Indígena do Xingu em 2008. "Insegurança para o desempenho de intervenções clínicas e treinamentos dos AIS no momento da inserção no trabalho, percepção das lacunas da graduação, e necessidade de desenvolver habilidades nas relações" compunham a percepção sobre o trabalho nesta terra indígena (RECH, 2008 p.173).

Chama atenção, nas falas dos profissionais, a ausência de algumas questões sobre as características do trabalho. Nenhum dos participantes mencionou sobre atuação como educadores. Na Política Nacional de Atenção à Saúde dos Povos Indígenas a formação de profissionais indígenas, em especial o AIS, é destacada pela sua importância na efetivação do subsistema. Os profissionais da EMSI devem participar da formação dos AIS, atuando como instrutores/supervisores. Na prática, esta atividade tem se configurado como atribuição quase que exclusiva dos profissionais enfermeiros. No PIX, a última iniciativa sistematizada de formação de profissionais indígenas foi concluída em $2012 \mathrm{com}$ a formação de 55 AIS, contando com a franca participação dos profissionais da EMSI durante todo o período em que foi desenvolvida. Segundo Oliveira (2005b, p.252), essa era uma oportunidade dos profissionais "aproximarem-se do mundo do Xingu". De acordo com Rech (2008), naquele momento, a dimensão educativa do trabalho era percebida e orientada aos profissionais logo na inserção no trabalho. Após 2012, nenhuma outra proposta de formação sistematizada foi implementada. Essa pode ser uma das razões para o afastamento dos enfermeiros das atividades de formação dos profissionais indígenas. Esse afastamento sinaliza para uma falta de norteamento sobre a atuação profissional, bem como para o não reconhecimento de que a formação dos profissionais indígena não se encerra com a conclusão do curso. Pelo contrário, o processo de aprendizado prossegue e se dá no cotidiano do trabalho. 
A interlocução com a educação escolar indígena também não foi apontada por nenhum participante. No PIX, o espaço da escola e os professores sempre foram mobilizados como apoio ao trabalho de saúde, em especial nas ações de educação em saúde nas comunidades e a formação dos profissionais indígenas. Entre os produtos dessa interlocução entre saúde e educação estão os livros didáticos bilíngues, produzidos pelos professores e pelos profissionais indígenas de saúde abordando diversos temas, dente eles a saúde.

Temas importantes relacionados ao modelo de atenção como: territorialidade e vigilância também estiveram ausentes nas falas.

\subsection{2 - Quem são os indígenas sob o ponto de vista dos} profissionais

Simplicidade e humildade foram palavras utilizadas pelo participante quatro para caracterizar os indígenas e sua relação com o mundo.

Eles querem ficar aqui dentro, eles gostam da comida deles, eles não gostam da comida da gente, e eles são felizes com o pouco que tem. [...] E você não vê maldade quando um indígena te chama para casa dele, ele tem a maior satisfação de te receber na casa dele, tenta te agradar mesmo com toda a humildade da família. Humildade na nossa visão. Só que para eles, aquilo é tudo maravilhoso, mas a casa deles tem muito pouca coisa (Participante 4).

As falas da participante um apontam para uma relação de subordinação dos indígenas em relação aos profissionais de saúde.

Eles são bem aconchegantes com a gente. Se a gente precisa fazer, por exemplo, um exame físico neles, eles estão à disposição. Se você pede, eles te deixam você conversar com eles direitinho (participante 1). 
As colocações apontam para concepções bastante "formatadas" acerca dos indígenas. $O$ indígena humilde, que se contenta com o pouco que tem e que tem pouco a oferecer, são marcas características de um estereótipo moldado pelo signo da falta. Apontam também uma relação com os indígenas e uma atuação profissional pautadas na bondade e na caridade reforçando a posição de submissão e de inferioridade historicamente atribuída a este grupo.

A perpetuação das concepções equivocadas sobre os indígenas sinaliza a dificuldade de relativizar e redução da potencialidade e do valor das relações interculturais.

\section{5 - OS CAMINHOS PARA CONSTRUÇÃO DE COMPETÊNCIA \\ Aprende-se trabalhando, mas sofre mais para aprender. Sofre mais, principalmente sozinho.}

(Participante 10)

Todos os participantes reconheceram a vivência como uma fonte de aprendizado, um caminho legítimo para a compreensão e a apreensão do trabalho e a consequente qualificação da prática profissional. Numa autoavaliação sobre a atuação profissional, todos se veem mais qualificados para o trabalho e também mais seguros e confiantes.

Uma vez imersos no contexto de trabalho dentro da terra indígena, os profissionais passam a procurar por recursos que possam auxiliá-los a dar respostas às demandas que vão se apresentando. Cada profissional segue uma trajetória particular rumo à qualificação, determinada pela individualidade do processo de aprendizado e pela particularidade da vivência de cada um. Cada qual a seu tempo e a sua forma. Contudo, algumas questões se colocaram como comuns ao grupo dando pistas sobre características importantes do processo de aprendizado neste contexto. A permanência dentro da terra indígena foi apontada como condição indispensável ao conhecimento. Os indígenas e os enfermeiros da equipe se destacaram no papel de educadores e o aprendizado se revelou como um processo espontâneo e permanente, que ocorre em diversos espaços e momentos da vivência 
de atuação do profissional não se restringindo às atividades e rotinas do trabalho em saúde. O aprendizado também não se restringiu ao campo profissional. Pelo contrário, estendeu-se para as esferas da vida pessoal.

\subsection{1 - Como, Com Quem e O Que se Aprende: Saber Fazer e Saber Ser}

As colocações dos participantes demonstraram que os principais recursos mobilizados pelos profissionais recém-inseridos no trabalho em busca de qualificação são: o conhecimento repassado pelos profissionais mais experientes. indígenas e não indígenas; o conhecimento repassado pelos indígenas da comunidade; e o conhecimento adquirido de forma autodidata por meio do estudo.

Foi identificado que, de início, o profissional assume uma postura de reprodução do comportamento e da atuação de profissionais mais experientes, naquele momento considerados como detentores do conhecimento sobre a realidade e, portanto, sabedores do que é certo ou errado. Um saber fazer vai sendo adquirido com a experiência e apoiado em referenciais externos. A valorização da experiência é uma unanimidade nas falas.

Tem pessoas com doze anos na saúde indígena, outros já trabalham ha quase quatro anos. Então, eles sabem (Participante 7).

O que eu mais me apeguei mesmo foi com as pessoas que tinham mais experiência em área. Porque não adiantava eu pedir orientação pra alguém que não sabia da realidade lá de dentro. Eu procurei as pessoas que já estavam há mais tempo mesmo em área para pedir qual era a melhor forma, qual o melhor caminho para seguir (Participante 6).

As pessoas que tem mais experiência, eu vi elas como exemplo (Participante 4).

Ficou evidente o estabelecimento de uma dinâmica de reprodução de práticas e atitudes, em que aqueles considerados mais experientes atuam como norteadores 
para os mais novatos, ensinando sobre como proceder e se comportar, o modo de estar e de agir no espaço de trabalho.

Esse caminho abre espaço para a reprodução de práticas equivocadas e inapropriadas. Os participantes cinco e seis relataram sobre a prática de oferta imprudente de medicamentos aos indígenas logo no início do trabalho.

Não apenas as práticas, como também os pontos de vista e as interpretações que as embasam passam a ser reproduzidas a partir da transmissão entre os profissionais. Elas se solidificam como verdades e assumem a condição de conhecimentos a serem aprendidos, e que irão impactar as atitudes dos profissionais, um saber ser. Dessa forma, a dinâmica de reprodução se dá não apenas na maneira como os profissionais desempenham as atividades, na tomada de decisões, como também no comportamento frente a várias questões do dia a dia do trabalho e na permanência dentro da terra indígena. Neste momento, parece não haver espaço para a reflexão e, de forma acrítica, os profissionais recém-ingressos vão incorporando um modo de ser e fazer neste contexto de trabalho.

Para um observador externo, esse parece ser um caminho natural e, até mesmo, lógico, assim como parece ser para os participantes que vivenciam esta experiência.

Acho que aqui todos os profissionais que entram é dessa forma, quando chegam, o pessoal vai passando (Participante 9).

Para o participante nove, essa dinâmica de reprodução de práticas e de atitudes também pode ser entendida como uma consequência da chegada de um novo profissional em um contexto onde as rotinas já estão estabelecidas. Para um profissional recém-formado, sem experiência em um campo tão específico - situação de muitos dos participantes - não é fácil questionar rotinas já instituídas.

Como foi o meu primeiro serviço como enfermeiro, eu já cheguei em um polo onde já estavam acontecendo as coisas. Os profissionais que ali trabalham disseram "Olha, vai ter que ser feito assim, assim." Aí a gente vai fazendo (Participante 9). 
O enfermeiro mais experiente parece ser uma referência importante para os recémingressos no trabalho. Isso pode ser explicado pela preponderância do papel do enfermeiro no trabalho da equipe, pela identificação profissional e até mesmo pela falta de outro profissional que cumpra esse papel.

Apesar disso, as histórias dos participantes mostram que nem sempre o enfermeiro foi o profissional que estava disponível para oferecer ajuda aos iniciantes. A participante seis vivenciou o processo de introdução no trabalho duas vezes, a primeira como integrante de EMSI em um ponto de apoio e a segunda vez como responsável técnica pela imunização em um dos polos base. Nas duas ocasiões, a profissional foi acolhida e orientada por um profissional técnico de enfermagem.

No começo, foi bastante difícil pela falta de orientações que lá a gente não tinha muito. Quem me ajudou muito nesta parte foi a técnica de enfermagem que ficava comigo, que já tinha uns nove anos de experiência. Acabou que ela foi a minha orientadora lá. Me orientou várias coisas que não deveriam ter sido orientadas, que ela mesma tinha aprendido também de forma errada e foi passando para mim (Participante 6).

Eu estava sozinha, foi muito intenso para mim. Então eu concordei em ir, só que eu não tive as orientações novamente igual quando eu entrei para área mesmo. $O M$ (enfermeiro responsável) saiu e não deixou nada. A única pessoa que estava comigo era a $J$ (técnica de enfermagem). Então era ela que estava me orientando mesmo, me norteando. Eu tentei fazer o serviço da forma como a Júlia estava me orientando. Achei que por ela já estar, sei lá há quanto tempo na vacina, ela já sabia o suficiente (Participante 6).

Alguns profissionais apontaram a importância da atuação do médico como um educador no cotidiano de trabalho, especialmente no que diz respeito ao manejo das demandas clínicas. Como já foi citado anteriormente, o Programa Mais Médicos para o Brasil colaborou para o enfrentamento da dificuldade de provimento e fixação dos profissionais médicos nas áreas indígenas, até mesmo nas mais remotas. Todos os participantes da pesquisa foram inseridos no trabalho em área em um momento privilegiado, no que diz respeito à presença do profissional médico nas equipes, todos intercambistas vinculados ao PMMB. Contudo, a maior disponibilidade de médicos nas equipes parece não garantir a atuação destes como educadores. Para um dos participantes isso se deve, em parte, à organização da escala de trabalho, 
que nem sempre garante o encontro entre médicos e demais profissionais da equipe durante o período em que permanecem em área.

Essa dinâmica de reprodução de práticas e atitudes parecer constituir uma ferramenta indispensável para que o profissional consiga se estabelecer minimamente no contexto dando conta de todas as dificuldades iniciais do processo. Os conhecimentos fornecidos pelo outro, aqui legitimado e reconhecido em sua experiência, desempenham um papel fundamental no processo de acomodação que permite que o profissional se sinta mais seguro e mais distante do estranhamento inicial.

Apesar da importância desse momento inicial, os participantes reconhecem que o aprendizado se dá de forma constante e quase sempre mediado pelo outro. Ainda que haja um destaque inicial da figura do profissional não indígena, em especial do enfermeiro, foi possível identificar que os indígenas se sobressaem como os principais atores que colaboram com o aprendizado dos profissionais que atuam em campo, contribuindo para a construção de competências para o trabalho. Como era de se esperar, cabe os indígenas, profissionais de saúde ou não, o papel fundamental de mediadores no aprendizado sobre o universo cultural. São eles que ajudam o profissional iniciante a permanecer no ambiente, decifrar seus códigos e a aprender a se comportar de forma mais apropriada e respeitosa frente à cultura.

Todos um pouco. O médico, os outros enfermeiros também. Quem tem mais tempo em área também, com certeza ajuda bastante. Mas quem mais me ensina são os indígenas (Participante 4).

Os próprios AIS. Eles são os principais. É com eles que nós vamos aprender as tradições, o jeito de trabalhar, a forma do trabalho (Participante 7).

Os profissionais indígenas são também, muitas vezes, a fonte do aprendizado técnico, especialmente os auxiliares de enfermagem.

Eu me sinto também muito segura quando eu estou com ele (auxiliar de enfermagem indígena). Ele me ajuda muito, me ensina muito, me mostra. Eu nunca tinha feito uma sutura. Ele me ensinou a fazer. 
Ensinar, falar, mostrar direitinho como que é. Na questão do exame físico foi com ele (Participante 2).

Eu não tenho vergonha de dizer que eu aprendi muito com eles (profissionais indígenas), muito mesmo. A minha primeira sutura, eu cheguei lá, eu só tinha técnica de teoria, mas para colocar a mão na massa mesmo eu nunca tinha feito (Participante 5).

A aproximação com os especialistas tradicionais parece ser fonte não só de aprendizado como também de segurança para os profissionais.

Eu criei um vínculo muito grande com a parteira da aldeia. Eu sento, converso com ela e com a filha dela também. Criei um vínculo bastante próximo eu e ela, para ela estar me falando o que pode e não pode, o que é da cultura. Quando tem os partos ela me chama. Ela me ensinou bastante sobre o parto. O pré-natal eu não faço sozinha. Eu trago ela junto comigo para fazer o pré-natal. Eu aprendi muita coisa com ela e hoje em dia eu me sinto mais segura para fazer um pré-natal. Esse vínculo com ela e com a filha dela está me ajudando bastante também (Participante 2).

Os indígenas mais velhos também são apontados como fonte de conhecimento, principalmente sobre o universo cultural.

Para alguns participantes, este momento inicial em que a única referência parecia ser o profissional mais experiente, seja ele indígena ou não, foi seguido por uma postura crítica, passando a questionar sobre a coerência e a adequação de várias atitudes e práticas aprendidas e reproduzidas. Retomando o exemplo da oferta de medicamentos citada anteriormente, a participante seis descreve que sua postura crítica foi despertada pelo contato com outros profissionais que atuavam nas outras abrangências.

A gente pegava uma bandejinha e ia fazer as visitas domiciliares. Só que isso era diariamente. Todos os dias a gente passava nas casas para ver se estava tudo bem e acabou criando um costume, um vício de todos os dias ter alguém passando nas casas com uma bandejinha de remédio para ver esse estava tudo bem. Se estivesse com dor de cabeça tomava um remedinho. [...] Porque eu entrei, ela já tinha o costume de fazer e eu já entrei na onda dela também. Eu achei que era o correto na época. Depois eu fui conversar com outros 
colegas que disseram: "Nossa, para que isso? Não tem necessidade" (Participante 6).

Situação semelhante também foi relatada pelo participante cinco, quando discorreu sobre como passou a questionar a suposta "excelência" da capacidade técnica dos profissionais indígenas, no momento em que percebeu uma certa padronização de condutas frente a casos de crianças com quadro sugestivo de infecção respiratória.

\begin{abstract}
Porque os AIS... eu sabia que eles tinham uma formação e eu sempre respeitei muito essa formação dele. Mas eu vi que estava tudo muito mecânico, e eu sempre tentei trabalhar em conjunto com eles. Então eu me lembro que eu auscultava e pedia para um deles: "ausculta para mim". E todos eles tinham o mesmo discurso: ausculta com presença de roncos, sibilos e estertores. Daí eu perguntava de novo, a gente olhava junto de novo. Era um discurso meio que igual. Eu falei: "gente, esse trem não está certo" (Participante 5).
\end{abstract}

A interlocução entre profissionais de abrangências diferentes parece colaborar convocando o profissional a pensar sobre sua prática a partir da experiência do outro, por meio do diálogo sobre semelhanças e diferenças e as estratégias adotadas frente às dificuldades. Isso aponta para a importância da troca de experiências como uma fonte de aprendizado e reflexão.

Outros atores que também colaboram com o aprendizado são os profissionais de fora, que não integram as EMSI, mas que participam de atividades desenvolvidas em área de forma pontual ou regular. Foram citados os profissionais que compõem o Núcleo de Apoio à Saúde Indígena, que são referência técnica para as equipes de campo em várias áreas, além dos profissionais vinculados à UNIFESP.

Os participantes enfatizaram a oportunidade de aprendizado garantida durante as atividades desenvolvidas pela UNIFESP, especialmente as etapas de imunização.

Esse trabalho que vem sendo feito pela UNIFESP, com a equipe que já tem um conhecimento maior, facilita muito nosso trabalho. A E. (enfermeira da UNIFESP responsável pela imunização em três dos polos base) foi a minha primeira referência. Depois dela vieram outras referências. Muitos médicos passaram. Eu tenho contato de 
médicos que vieram, que passaram para uma ação ou para conhecer e que eu tenho contato e hoje se eu os aciono, eles me ajudam, eles me dão um retorno (Participante 5).

Aqui, o que eu fico esperando mais é quando passa a vacina, porque eu sei que ela vai trazer bastante novidade e ensinar muita coisa (Participante 2).

Isso demonstra que a universidade ainda cumpre um papel na formação de profissionais, o que, em certa medida, colabora para suprir as demandas de formação de recursos humanos no DSEI.

Outro caminho para a qualificação apontado pelo grupo foi o estudo individual. Alguns participantes apontaram a busca por conteúdos técnicos em livros e por meio da internet como uma prática que ocorre, em geral, nos momentos de folga. $O$ estudo dentro de área fica impossibilitado pela disponibilidade de acesso a internet, falta de tempo e disposição.

Quando eu estou em casa, fora de área é a internet e livros (Participante 2).

Porque aqui dentro de área você não consegue estudar. Eu já tentei várias vezes trazer material. Mas, chega uma hora que você está tão cansado à noite, ou preocupado em interagir com os colegas da convivência que você não traz (Participante 5).

Os conteúdos buscados, em sua maioria, estão relacionados às demandas técnicas mais presentes no dia a dia do trabalho: prescrição medicamentosa, atenção ao prénatal, exame físico entre outros.

Os protocolos clínicos foram pouco citados pelos participantes. Esses protocolos foram implantados pela UNIFESP e compunham um conjunto de ferramentas que auxiliavam a implementação do modelo de atenção, levando em consideração o perfil epidemiológico, a realidade do serviço e a composição das equipes de saúde. Para alguns, o uso de protocolos foi uma novidade. Outros consideraram os protocolos utilizados no PIX muito diferentes daqueles que conheceram em serviços anteriores. Em todas as falas os protocolos foram reconhecidos como uma importante ferramenta de apoio técnico aos profissionais. Os protocolos ajudam o 
enfermeiro a atuar de forma correta e amparam na tomada de condutas, não sendo recomendável aos profissionais recém-inseridos no trabalho ignorá-los.

Proatividade, autocrítica e reflexão foram apontadas pelos participantes como indispensáveis ao profissional no processo de aprendizado. Sobre a necessidade dessa postura de busca pelo conhecimento, o participante cinco criticou a atitude dos colegas de trabalho que, segundo ele, em geral, não buscam o conhecimento amplo sobre questões e dificuldades vivenciadas no cotidiano. Para ele, tal comportamento pode ser indicativo de uma visão equivocada sobre a não necessidade de conhecimento para trabalhar com indígenas.

Porque eu vejo muito colega que não busca um conhecimento amplo sobre alguma coisa, sobre determinado assunto. Eu vejo as coisas muito limitadas. O que é, para que serve, como faz, porque isso já basta para passar. Eu acho que soa como um preconceito, de repente achar que é limitado o conhecimento do indígena. Mas, às vezes, você passa vergonha. Porque muitas das vezes você vai discutir e a conversa gira para uma conversa ampla e que, se você não estiver preparado, você passa vergonha (Participante 5).

Os participantes quatro e oito falaram sobre a importância da abertura para uma avaliação pelo outro.

Eu tive a humildade de falar: "Fulano, o que você está achando do meu trabalho? O que você acha que eu tenho que melhorar?" Isso dá uma abertura para as pessoas te falarem (Participante 4).

Sempre com muita humildade. Sempre fazendo uma auto-reflexão, você mesmo do seu trabalho e vendo as falhas. Como será que está sendo o meu trabalho? Eu sempre pensava assim. Eu sabia onde eu estava errando, onde estava sendo ruim (Participante 4).

De imediato, o DSEI não foi citado pelos participantes como um ator no processo de aprendizado deles. Apesar disso, quando interrogados pela entrevistadora, todos os participantes concordaram com a importância do DSEI como um agente formador dos profissionais que atuam em área. 


\subsection{2 - O Espaço e o Tempo do Aprendizado}

O que eu sei hoje foi o que eu aprendi aqui.

(Participante 6)

A permanência dentro da terra indígena aparece como condição indispensável para a compreensão sobre o trabalho neste universo tão particular. Todas as situações que promovem acesso à informação, reflexão, discussão e troca de experiências, mediadas ou não por diversos atores, foram apontadas como favoráveis ao aprendizado. Além das já citadas atividades desenvolvidas pela UNIFESP ou pelos profissionais do NASI, os atendimentos na UBS, as visitas domiciliares e o trabalho nas aldeias também foram identificados como espaços de aprendizado. Isso aponta para a importância da vivência do trabalho e da interlocução com o outro, como caminho privilegiado de aprendizado, se sobressaindo à forma mais autodidata. Reforça também o potencial do trabalho como espaço de aprendizado.

As visitas domiciliares e o trabalho nas aldeias se destacaram como espaços privilegiados pela possibilidade de aproximação com os indígenas, condição fundamental para a criação de vínculo e construção de uma relação de confiança. A aproximação com os indígenas também permite maior conhecimento sobre a cultura e sobre as práticas tradicionais de cuidado e cura.

Quando você começa a estar mais perto, mais presente com eles em vigilância, na visita domiciliar, eles acabam que se aproximam mais de você. Não só esperar na UBS, ele chegar perto de você e te falar. Você estar junto com eles mesmo. Estar indo na casa dele, estando junto ali (Participante 3).

As situações de emergência também são citadas como gatilho do processo de aprendizado, reforçando a necessidade de estudo e conhecimento, especialmente sobre as questões técnicas.

Acho que são os casos quando vem essas ações em que a gente tem contato fácil com o médico. É quando a gente vai expor um caso que a gente já vivenciou e está acontecendo agora de novo e a gente 
não sabia lidar. A gente pode pedir orientação para eles. E quando tem essas emergências mais graves em que você se obriga a aprender (Participante 6).

Foi possível identificar que as atividades do trabalho em saúde não delimitam o espaço do aprendizado. Pelo contrário, os participantes falaram sobre o quanto as atividades do dia a dia de permanência em campo colaboram com o conhecimento, especialmente acerca da cultura e da história dos povos com os quais trabalham.

\begin{abstract}
A gente tem as rodinhas de conversa entre a gente, os profissionais. Isso também ajuda bastante a aprender. De vez em quando eles (os indígenas) vêm conversar com a gente. Sentam lá com a gente e vai batendo papo. Daí a gente sabe o que realmente está acontecendo com uma pessoa, com a outra [...] (Participante 1).
\end{abstract}

Curiosamente, pouco foi colocado sobre estratégias tradicionais de ensino/aprendizado, como oficinas, cursos e capacitações. Colocações sobre este tipo de atividade só se fizeram presentes nas falas a partir do questionamento da entrevistadora.

A importância das capacitações foi associada especialmente ao momento de inserção dos profissionais no serviço. A partir de reflexões sobre suas próprias experiências de inserção no trabalho, os participantes consideraram indispensável a oferta de capacitação para os recém ingressos, especialmente com conteúdos de antropologia e conteúdos técnicos relacionados à atuação do enfermeiro dentro de área. Acolhimento, orientações sobre a realidade de trabalho $e$ um acompanhamento sistemático no momento de inserção foram também apontados como indispensáveis.

Acho que antes de colocar um profissional em área, lá fora, no DSEI, poderia ter um... vamos dizer assim... um treinamento, não sei... uma capacitação. Uma capacitação antes de você entrar em área, porque o trabalho aqui é diferente (participante 2).

Então, o que pode ser oferecido é algum instrumento, um norteamento antropológico, da realidade epidemiológica, da realidade ambiental. Porque é isso que depois a gente sofreu muito 
aqui. O profissional precisa ter um pré-conhecimento da parte sociológica, cultural para ajudá-lo a viver o início de tudo. [...] mostrar para o profissional que é uma realidade diferente, uma população diferente, mas também esse outro lado de estar fora de tudo, do conforto que ela vive e tal (participante 8).

Com base em suas experiências pessoais, os participantes apontaram um período entre três e seis meses como período o mínimo para que o profissional se sinta à vontade e se aproprie do contexto, dominando minimante questões importantes sobre a organização do trabalho e sobre a relação com os indígenas. Com exceção do participante dez, que esboçou um plano mais consistente e de longo prazo necessário à adaptação do profissional, todos os demais fizeram apontamentos nos quais a adaptação se configura como um processo estanque, limitada por um curto período de introdução ao trabalho.

\subsection{3 - A Certeza do Aprendizado}

Aqui eu aprendi muito, mudei muito a minha pessoa.

(Participante 2)

Ainda tenho muito para aprender, mas eu me sinto mais segura.

(Participante 8)

Pereira (2012) discorre sobre a possibilidade dos profissionais de saúde serem afetados nessa experiência de trabalho na saúde indígena. O autor caracteriza a afetação como resultado do processo de interlocução com o outro, com a alteridade. Ao se depararem com situações que não podem ser traduzidas ou encaixadas no repertório de saberes teóricos e práticos que possuem, os profissionais são impelidos a se distanciarem de suas convicções e a reconhecerem os limites de sua atuação sob o paradigma da biomedicina. Ser afetado se traduz no reconhecimento de outros saberes em postura oposta às traduções etnocêntricas que são bastante comuns neste contexto. Nos relatos foram recorrentes falas dos participantes apontando para insuficiência da biomedicina e de todo o seu aparato organizacional e tecnológico no enfretamento de situações diversas vivenciadas no trabalho. Os profissionais reconhecem os limites de seu conhecimento e a necessidade de se abrirem para o conhecimento do outro. 
Em sentido semelhante, Ceccin (2012, p.27) aponta que os profissionais precisam "ser afetados pelos signos que informam o cotidiano e as necessidades sociais em saúde" para que desenvolvam competências.

Nesse trabalho na saúde indígena, ser afetado significa conseguir identificar que se está atuando em um território específico, que abarca uma outra realidade social, cultural, epidemiológica e com populações expostas a uma situação de vulnerabilidade historicamente construída. Os profissionais estão conseguindo captar os signos, serem afetados e reconhecerem de fato o contexto e as demandas do trabalho?

Todos os profissionais reconheceram a aprendizagem e apontaram modificações na forma de se relacionar com o trabalho. Afirmaram sentirem-se mais à vontade e com mais domínio sobre o trabalho em área, o que os torna mais confiantes e seguros.

Com certeza, hoje eu tenho muito mais segurança do que eu faço. Hoje, mesmo que eu não saiba, eu tenho uma segurança para lidar com a situação, de tentar buscar um meio, de tentar fazer as coisas acontecerem do jeito que tem que ser. Eu não sei tudo, mas eu consigo ter esse discernimento de entender a situação e buscar uma alternativa para agilizar as coisas ou para agilizar assistência, para atender naquele momento. E essa segurança eu acho que é no dia a dia mesmo que vai te dando, é a vivência do trabalho. Se eu voltar lá atrás e hoje, é totalmente diferente (Participante 5).

Dos quatro primeiros meses para cá, eu evoluí bastante na questão tanto da parte profissional aqui dentro trabalhando, quanto da parte do convívio com o pessoal mesmo (Participante 7).

A necessidade de respeito às concepções indígenas e de valorização das práticas tradicionais também foi reconhecida. Foram comuns falas sobre mudanças na postura profissional e na forma como passaram a enxergar a realidade na qual estão inseridos. Com o tempo, também adquiriram uma melhor compreensão sobre os aspectos culturais e sobre a forma como lidar com eles.

[...] com o passar do tempo, mudou. Mudou bastante, a gente já consegue ter uma relação diferente principalmente com o trabalho com o pajé (participante 10). 
[...] aprendi bastante também além do relacionamento. Com as mulheres, antigamente eu achava que elas não estavam me entendendo quando a gente conversava. Então eu tratava elas assim, sabe? Como se não fosse uma pessoa, sabe? Mas à medida que eu fui mudado que elas foram vendo que eu tratava elas com mais valor, eu ganhei vínculo. O relacionamento, o vínculo, para mim isso foi um aprendizado muito importante (Participante 8).

Mesmo sentindo-se mais preparados para o trabalho, os participantes reconhecem o caráter contínuo do aprendizado.

É um aprendizado constante. A cada dia surgem situações, surgem momentos que te fazem repensar enquanto profissional, enquanto pessoa. Dentro da saúde indígena você aprende a cada dia, sempre tem alguém para te ensinar alguma coisa diferente, sempre tem alguma coisa que pode ser mudada para melhorar, para que as coisas aconteçam (Participante 5).

Foi possível notar também que experiência do trabalho dentro da terra indígena é uma fonte de aprendizado que extrapola a dimensão profissional. O plano pessoal também é afetado pela experiência. Apesar das colocações acerca da qualificação técnica e dos conhecimentos sobre como lidar com o outro, com a alteridade, quando interrogados sobre o maior aprendizado proporcionado pela experiência, muitos participantes enfatizaram os reflexos sobre o comportamento pessoal.

Aqui eu aprendi muito, mudei muito a minha pessoa. Todo mundo fala: "Depois que você foi para lá, você é outra pessoa". Eu aprendi muito a dar valor a família, ao companheiro de trabalho que está ali ao seu lado. Conviver ali dia e noite. Eles (indígenas) ensinam muita coisa (Participante 2).

Eu acho que eu aprendi a respeitar mais as pessoas depois que eu vim para cá. Aprendi a dar valor a tudo. Sei lá... muita coisa (Participante 6).

$O$ relacionamento. O que eu mais aprendi foi relacionar com as pessoas. Para mim é muito difícil isso, eu tive que aprender (Participante 8). 
Talvez isso tudo possa ser suficiente para afirmar que os profissionais são efetivamente afetados pela experiência de trabalho. Por outro lado, foi identificado também que os participantes apresentam dificuldade em reelaborar velhas convicções e representações solidificadas. Isso fica claro na forma como caracterizam o trabalho dentro da área indígena, a atuação do enfermeiro e os indígenas. Dessa forma, não se pode mensurar o quanto o discurso sobre mudança e aprendizado se traduz em uma efetiva prática profissional qualificada no cotidiano do trabalho.

\section{6 - SOBRE O APRENDIZADO E AS COMPETÊNCIAS}

\section{[...] a competência é como a inteligência que vem depois.}

Ricardo B Ceccin

No trabalho em saúde no Parque Indígena do Xingu, os profissionais são imersos em um contexto onde estão presentes um conjunto de elementos necessários à aprendizagem e ao desenvolvimento de competências.

Os conteúdos demonstraram que o aprendizado é um processo vivenciado pelos profissionais que, a partir da inserção no trabalho vão, aos poucos, identificando os recursos necessários para a sua prática e passam a buscá-los. A vivência do trabalho vai apresentando ao profissional quais saberes, habilidades e atitudes são necessários e adequados para a sua atuação profissional. Na composição da competência profissional alguns elementos se destacaram como mais expressivos, entre eles, conhecimentos e atitudes que guardam uma relação direta com a interculturalidade.

\subsection{1 - O Aprendizado Significativo}

Apesar de não estarem inseridos em uma estratégia oficial de formação é possível afirmar que o processo de aprendizado vivenciado pelos profissionais caracteriza uma experiência de aprendizagem significativa. As duas condições necessárias a 
este tipo de aprendizagem estão presentes: conteúdos significativos e a busca ativa pelo conhecimento. $\mathrm{O}$ aprendizado está fundamentado na prática cotidiana e ganha sentido a partir da realidade de trabalho. A partir de situações vividas na prática os profissionais são impelidos a atuarem de forma ativa, a se mobilizarem na construção de novos conhecimentos.

Uma boa parte dos participantes teve acesso prévio a conhecimentos sobre o trabalho na saúde indígena durante a formação acadêmica. Alguns deles relatam inclusive visitas às terras indígenas durantes estágios curriculares. Essas experiências resultaram em um acúmulo de conhecimentos. Contudo, foi somente a partir da vivência e impulsionados pela imersão no contexto, que os conhecimentos adquiridos anteriormente se tornaram significativos.

É a vivência que torna significativo o que já foi aprendido e abre portas para os novos conhecimentos que serão agregados, modificando continuamente o repertório de conhecimentos que os profissionais já possuem e repercutindo na atuação profissional.

$\mathrm{Na}$ aquisição dos novos conhecimentos, os profissionais recorreram ao cardápio de conhecimentos prévios adquiridos na formação acadêmica e na vida. Os participantes que haviam concluído a especialização em saúde indígena salientaram a importância dos conteúdos de antropologia, política e epidemiologia abordados no curso. Um deles fez associações entre as características do trabalho e conceitos do campo da saúde coletiva.

Os profissionais também contam com a participação de mediadores diversos que favorecem o processo de aprendizado. São indígenas e não indígenas ocupantes de posições variadas dentro do contexto de trabalho.

\subsection{2 - Os Elementos que Compõem a Competência Profissional} no Trabalho em Saúde no Xingu

O conceito de competência profissional utilizado neste estudo tem como eixo central a compreensão de que a competência é formada por três componentes básicos conhecimentos, habilidades e atitudes - que precisam ser mobilizados de forma 
adequada e oportuna no enfrentamento de situações vivenciadas no trabalho. No campo da saúde, a competência profissional também implica em uma atuação capaz de impactar a situação de saúde e colaborar com a efetivação dos princípios do SUS.

A competência profissional para a atuação no interior das terras indígenas pode ser definida como a mobilização de conhecimentos (saber), habilidades (saber fazer) e atitudes (saber ser) necessários ao trabalho em contexto intercultural com vistas a uma atuação profissional que colabore com a melhoria do quadro sanitário do território e com a efetivação da atenção diferenciada, princípio norteador da assistência à saúde dos povos indígenas em nosso país.

As principais habilidades demandadas aos profissionais estão relacionadas ao desempenho técnico exigido para o trabalho no campo. Como já foi colocado anteriormente, o trabalho no Xingu demanda conhecimentos e a capacidade de executar tarefas técnico-assistenciais que extrapolam o campo de domínio do profissional enfermeiro. No desempenho destas habilidades, os profissionais também enfrentam as dificuldades advindas da falta de estrutura adequada para o trabalho. A reprodução configura como a principal estratégia para superar as deficiências do saber fazer.

Talvez seja o campo das atitudes o mais expressivo e também o mais revelador dos desafios enfrentados para o trabalho no contexto da interculturalidade e em processos de trabalho organizados à maneira do que foi encontrado no Xingu.

Os conteúdos apontaram que a capacidade de se relacionar de forma apropriada com o outro é a atitude a mais exigida para o trabalho. A imersão no contexto intercultural e as características da organização do trabalho impõe a necessidade de relacionar-se constantemente com os não indígenas, com os indígenas e suas distintas concepções sobre as coisas do mundo, incluindo a saúde.

Uma característica importante do trabalho em saúde é que ele é possui uma dimensão relacional. O relacionar-se com o outro é uma condição inerente ao trabalho em saúde e à produção de cuidado. Esta dimensão relacional faz parte do campo das tecnologias leves e possui preponderância no ato de cuidar (Merhy 1997). O estabelecimento de relações e vínculos positivos entre os profissionais, e 
entre estes e os usuários, ocupa lugar central entre as diretrizes que norteiam iniciativas de reorientação do modelo assistencial e de produção do cuidado em saúde individual ou coletivo, como, por exemplo, a Política Nacional de Humanização.

O trabalho dentro do Xingu se efetiva através do uso de tecnologia leves, essenciais para a geração de processos relacionais positivos e produtivos com os indígenas e entre a equipe, e necessários para exercer cuidados de saúde.

Dessa forma, o outro com quem o profissional se relaciona ora são os demais profissionais técnicos, ora são os indígenas ou ainda uma série de elementos presentes no contexto que remetem à relação intercultural. A capacidade de relacionar-se com os profissionais e lidar com a convivência interpessoal intensa é a garantia de uma boa permanência em área, contribuindo para a efetivação do trabalho em equipe. A relação com os indígenas, seus modos, costumes e concepções também trás implicações diretas para a qualidade da assistência à saúde individual e coletiva.

É nessa dimensão relacional com os indígenas e suas culturas que a interculturalidade se faz presente de forma mais expressiva, colocando demandas ao profissional. Uma postura relativista, a capacidade de escuta, a disposição para o diálogo e a interlocução com os saberes e práticas indígenas, apontados como indispensáveis a um saber ser competente neste campo, parecem não constituírem atitudes simples, capazes de serem desenvolvidas e mobilizadas com facilidade. Para desenvolver tais posturas, consideradas essenciais nesse encontro com a diferença, o profissional é convocado a revisitar e questionar seus paradigmas e suas convicções.

Conhecer o diferente passa por uma reflexão sobre a nossa prática, confirma a necessidade de se dispor a ouvir, se dispor ao diálogo. Essa é uma das habilidades mais importantes que os profissionais de saúde que atuam em saúde indígena devem exercitar e construir. Quando nos dispomos a ouvir, não só ouvir, mas escutar, e exercer nosso papel de interlocutores, estamos trabalhando com a perspectiva de repensar nossa própria cultura, relativizar nossos próprios paradigmas (MENDONÇA, 2010, p.182). 
Conseguir valorizar e respeitar os modos, concepções e costumes indígenas, admitindo-os como legítimos, passa por um reconhecimento desses povos muito diferente do que a maior parte dos profissionais carrega. Passa também por repensar valores e concepções sobre a profissão e sobre a atuação profissional. Questionar e repensar tais convicções é tarefa árdua e também desafiadora.

A respeito disso, ficou evidente o quanto as atitudes são moldadas na esfera individual, sendo influenciadas pelos valores e experiências prévias dos participantes. A forma como os participantes caracterizam o trabalho e os indígenas, é reveladora da força das concepções consolidadas que esses profissionais carregam consigo, evidenciando a influência do contexto sociocultural sobre $\mathrm{O}$ processo de aprendizado e sobre a atuação profissional de cada um. A dimensão sociocultural dos profissionais é destacada na matriz dialógica da competência como um dos fatores que permeiam o processo de aprendizado e a atuação profissional.

No trabalho em saúde as atitudes presentes nas relações entre os profissionais de saúde e os pacientes guardam uma dimensão ética. Na saúde indígena, o agir eticamente se traduz no respeito às concepções indígenas sobre o processo saúdedoença, quesito fundamental para a efetivação do princípio da atenção diferenciada.

Os conteúdos também revelaram o quanto o repertório de conhecimentos trazidos pelos profissionais se mostrou frágil ou insuficiente frente às demandas do trabalho. Apesar da simples aquisição de um conjunto de conhecimentos não ser suficiente para sustentar o desenvolvimento de competências, o componente saber tem grande importância sendo matriz sustentadora dos demais componentes saber fazer e saber ser. Assim como as ações técnicas estão ancoradas em conhecimentos teóricos trabalhados no espaço acadêmico, o desenvolvimento de atitudes também demanda uma sensibilização por parte dos profissionais, podendo ser despertada a partir de conhecimentos teóricos.

O campo da antropologia é fonte de conceitos-chave como, por exemplo, cultura, diálogo intercultural e relativismo cultural. O conhecimento sobre o perfil epidemiológico local, a história de contato e as particularidades socioculturais dos povos com os quais trabalha são essenciais para que o profissional entenda 0 contexto das demandas de saúde. Por fim, conhecimentos sobre o subsistema de 
atenção e a política que o norteia são imprescindíveis para entender o modelo de atenção proposto, bem como as implicações para a atuação profissional. Os conteúdos sobre política e antropologia foram reconhecidos como importantes pelos participantes que haviam concluídos a especialização em Saúde Indígena. Aqueles que tinham especialização em saúde indígena ou saúde pública fizeram referências a conceitos como vulnerabilidade, educação em saúde, promoção e prevenção em suas falas.

Curiosamente, colocações sobre a Política Nacional de Atenção à Saúde dos Povos Indígenas e sobre o subsistema não emergiram espontaneamente nas falas de nenhum dos profissionais. Da mesma forma, o princípio da atenção diferenciada também não foi citado.

O imperativo da interculturalidade expõe as fragilidades da formação acadêmica, cujos conteúdos estão muito distanciados das necessidades específicas deste campo de trabalho. Contudo, seria equivocado atribuir exclusivamente ao campo acadêmico a responsabilidade pela formação. É necessário considerar que a realidade de trabalho observada no estudo é bastante particular, só podendo ser conhecida e entendida a partir de uma aproximação. Voltando a uma pergunta já colocada anteriormente: é possível preparar para o trabalho?

As participantes afirmam ser possível um preparo básico anterior à inserção no trabalho, por meio da oferta de conteúdos de antropologia, perfil epidemiológico, informações sobre os povos do Xingu e suas culturas. Informações importantes sobre a organização do trabalho, ambiente e acomodações deveriam ser repassadas aos futuros profissionais já na etapa de entrevista, durante o processo seletivo. Todos entendem que esse preparo deve ser realizado pelo DSEI.

\subsection{3 - O Papel da Gestão do DSEI na Formação}

Com exceção do suporte ofertado pelos profissionais de fora, em especial aqueles vinculados à UNIFESP, todos os recursos adquiridos e mobilizados pelos enfermeiros são oriundos do espaço de trabalho. O processo de aprendizado e o desenvolvimento de competências parecem se restringirem ao interior da área 
indígena, efetivado na vivência do dia a dia em que trabalho e vida não têm seus limites definidos.

É esperado que o espaço da prática se consolide como privilegiado no processo de aprendizagem, especialmente por se tratar de um contexto tão específico como o apresentado no campo de estudo. Contudo, é possível afirmar que no Xingu, o aprendizado e o desenvolvimento de competência pelos enfermeiros também são afetados pela gestão e organização do trabalho.

Os conteúdos apontam para um distanciamento entre a gestão e o trabalho dentro da terra indígena. Nas colocações dos participantes, as referências ao DSEI constituem uma ausência e, quando presentes, estão vinculadas a queixas sobre o desconhecimento dos gestores a respeito da realidade do trabalho dentro de campo. As expectativas dos profissionais de acolhida, apoio e norteamento para o trabalho não são atendidas. Os profissionais do Núcleo de Apoio a Saúde Indígena são criticados pelo não cumprimento de sua atribuição principal, que é o apoio às Equipes Multidisciplinares de Saúde Indígena. Os participantes também se queixaram de falta de reconhecimento no trabalho, que gera desmotivação. Para eles, a decisão dos profissionais de virem trabalhar no interior das áreas indígenas precisa ser reconhecida já que tal decisão implica em um leque de restrições sociais e abdicações pessoais.

O DSEI é citado pelos participantes justamente na falta do cumprimento de seu papel como acolhedor, formador e direcionador do trabalho.

Muito, eles (profissionais do NASI) ajudam muito. Também teriam que cumprir este papel, principalmente eles. Mas eles vão entrar em área e ajudar? Essa é a minha pergunta também. Eu não sei. Eles podem ajudar lá, mas, se entrar junto pode ajudar também (Participante 8).

Porque o que acaba acontecendo é que quando você sai de área e vai passar no DSEI, os Responsáveis Técnicos te cobram muito. São vários fatores. Ou seja, se quando entra um profissional aqui dentro novo, se puder acompanhar seria a melhor forma (Participante 3).

Eu vejo que a equipe do DSEI não prepara o profissional para entrar. Simplesmente contrata o profissional, não passa nenhuma orientação, e joga o cara aqui dentro com a responsabilidade da equipe de área fazer esta introdução. A equipe do DSEI não sente esta responsabilidade de introdução do profissional (Participante 4). 
Enquanto gestor, cabe ao DSEI a responsabilidade pela formação profissional e pelo norteamento do trabalho. Para isso, a educação permanente e a parceria com centros formadores e universidades são caminhos apontados na PNASPI. O estudo não levantou informações a respeito de iniciativas de formação no DSEI. Contudo, os conteúdos sinalizam que o DSEI Xingu não tem conseguido cumprir com a função de formador. A despeito disso, o processo de aprendizado dos profissionais segue dentro do território, reforçando a relação entre prática e aprendizado. A UNIFESP parece seguir cumprindo um papel de colaborador na formação e na assistência à saúde neste território.

O distanciamento do DSEl faz com que o processo de aprendizagem se dê de forma mais autônoma. Segundo Mitre et al. (2008) a autonomia é o princípio que ancora as metodologias ativas. Isso não significa porém que o aprendiz seja capaz de lidar sozinho com o aprendizado. A aprendizagem é um processo complexo e a vivência não pode ser a sua única via, devido ao caráter individual da significação. Por isso é preciso criar espaços e ações direcionadas para discutir acolher e problematizar tudo o que foi vivenciado.

Nesse sentido é importante a figura do DSEI enquanto mediador do processo de aprendizado. A presença do DSEI ofertando momentos de discussão e aporte teórico colaboraria para uma experiência de aprendizado mais reflexiva e menos auto-dirigida, menos autônoma. Também colaboraria para que a experiência de trabalho dentro de campo fosse vivenciada de forma menos tensa, especialmente no período inicial do trabalho. $\mathrm{O}$ acolhimento requerido pelos profissionais teria assim $\mathrm{o}$ duplo papel de nortear o trabalho e minimizar as dificuldades advindas da imersão na interculturalidade.

A falta de orientação para o trabalho e o distanciamento do DSEI trazem implicações para o desenho do processo de trabalho, para o perfil da atuação profissional e também para o modelo de atenção.

A organização do trabalho dentro do território é definida por um conjunto de atividades e ações comuns que devem ser desempenhadas pelas equipes de campo e modificadas a partir das particularidades de cada Polo Base. Há também um 
conjunto de ferramentas de organização disponíveis. Contudo, o modelo de atenção se consolida a partir da atuação dos profissionais da EMSI. Entre eles o enfermeiro é figura de destaque. Além de se encontrar à frente do trabalho da equipe, ele conta com um perfil de a atuação caracterizado por um modo de ser e de fazer próprios, gerado de forma pouco orientada, a partir do enfrentamento dos desafios do trabalho e utilizando como principal recurso a reprodução de práticas e atitudes. Uma atuação distante do modelo proposto na PNASPI e do que já vinha sendo praticado nesta terra indígena antes mesmo da consolidação do Subsistema, por meio da atuação da UNIFESP.

\section{7 - O IMPERATIVO DA INTERCULTURALIDADE E OS LIMITES DO DIÁLOGO INTERCULTURAL}

As noções e os conceitos de interculturalidade surgiram e se desenvolveram na América Latina na década de 1970, e tomaram mais corpo nas décadas de 1980 e 1990 por diversos motivos, entre eles legitimar, defender e empoderar diversos grupos étnicos. A interculturalidade pode ser entendida como qualquer relação entre pessoas ou grupos sociais de diferentes culturas. As relações interculturais podem ser positivas ou negativas a depender da forma como se configuram. As relações negativas conduzem à anulação, desvalorização ou assimilação de uma das culturas enquanto que relações positivas se dão na aceitação da diferença e se estabelecem com o enriquecimento e o aprendizado mútuo, sem que nenhuma parte deixe de ser o que é (ALBÓ, 2004; RAYMUNDO, 2011; MENÉNDEZ, 2015).

A interculturalidade refere-se à inter-relação e à comunicação. Por isso, o diálogo é apontado como a principal ferramenta para efetivação de relações interculturais positivas. Para isso, o diálogo precisa ser pautado na compreensão, no respeito, na tolerância e no reconhecimento do outro (DIBBITS, 2010; RAMOS, 2001; UNESCO, 2009).

No campo da saúde as diferentes propostas de interculturalidade que também surgiram na América Latina a partir de questões da saúde indígena, e possuem um propósito comum: a possibilidade de articular a biomedicina com as práticas 
tradicionais, a partir de relações de respeito e reconhecimento, e não de dominação ou subalternidade. (RAYMUNDO, 2011; MENÉNDEZ, 2016)

No Brasil, o respeito às concepções, valores e práticas indígenas sobre o processo saúde-doença é o princípio central que sustenta a proposta de atenção à saúde para esses povos. A interlocução entre a biomedicina e as práticas tradicionais indígenas é uma das diretrizes da política que orienta o modelo de atenção. Nessa proposta, a interculturalidade está expressa num ideal de relações, interlocuções e vínculos entre indígenas e não indígenas. A efetivação dessa proposta depende de um conjunto de ações com implicações para os profissionais de saúde, para os serviços e as instituições. Nesse cenário, a atuação dos profissionais que compõem as EMSI, espaço privilegiado da interlocução com a diferença, ganha destaque. Para estes profissionais, projeta-se de forma prescritiva uma atuação profissional ancorada em relações dialógicas harmoniosas com os indígenas, seus modos e suas práticas.

Os resultados do estudo reforçaram que no trabalho em saúde indígena, a interculturalidade é a grande marca do contexto. Os conteúdos mostraram que mesmo antes do contato mais efetivo como os indígenas e com o trabalho, os profissionais foram atraídos pela diferença. Eles experimentaram um flerte com a diferença cultural a partir de experiências pessoais prévias. Uma vez inseridos no trabalho, a relação intercultural se tornou uma permanência. Contudo, apesar de seu caráter inerente ao contexto, a interculturalidade nem sempre foi percebida pelos profissionais de imediato. Foi possível identificar que, no plano individual, a vivência da interculturalidade foi compreendida de forma diferente pelos profissionais, sendo um ponto comum o reconhecimento tardio dessa situação. Embora os profissionais reconheçam que estão em contato permanente com o diferente, eles têm dificuldade de perceber que a interlocução com essa diferença se dá a todo momento, a despeito do tipo de atividade realizada neste cenário, onde os espaços de vida e trabalho são pouco delimitados. O apelo da dimensão técnica da atuação profissional impede que os profissionais percebam que, mesmo a realização de procedimentos "essencialmente" técnicos exige sempre uma interlocução com os aspectos culturais.

No trabalho no Xingu ficou explícito o quanto a dimensão relacional é exigida dos profissionais. Nesse plano individual, a qualidade da relação intercultural é 
determinada pelas atitudes e pela capacidade do profissional de se comunicar e se relacionar. A competência relacional é individual. Assim, o alcance de diálogos e relações mais ou menos positivos e produtivos profissionalmente é bastante variável, a depender de singularidades de cada um. As dificuldades enfrentadas por alguns dos profissionais na relação com os indígenas, já mencionadas anteriormente exemplificam isso.

Para Raymundo (2013, p.224) alguns fatores podem contribuir para que as relações interculturais sejam positivas: "conhecer a cultura do outro, conhecer a própria cultura, eliminar ou neutralizar preconceitos e ser capaz de estabelecer relações empáticas. [...] fazer uma leitura daquilo que não está explícito no momento da comunicação".

A comunicação e o diálogo tendem a ser mais facilitados quando os interlocutores partilham de um universo de significações comum. Quando contrário, a comunicação se estabelece com menos facilidade e tende a gerar problemas. Uma das dificuldades é escapar, desvencilhar-se do etnocentrismo, descentrar-se. Os estereótipos e preconceitos também podem constituir obstáculos à comunicação. $O$ maior desafio para o diálogo é conseguir equilibrar-se entre o universalismo etnocêntrico que anula as diversidades culturais e o extremo relativismo em que só a diferença existe (ROUANET, 1990; RAMOS, 20001; LORENZO, 2011; ARRUDA, 2015; PERUZZO, 2016).

A interculturalidade pressupõe conflitos e atritos, não sendo espaço de acomodação. O diálogo intercultural nem sempre será tranquilo ou alcançará o consenso. $\mathrm{Na}$ saúde indígena, interação e comunicação se dão em um contexto historicamente construído e fortemente marcado pela subjugação dos indígenas, aos quais se destina uma posição de permanente inferioridade. Além disso, todo o aparato que estrutura o modelo de atenção tende a privilegiar as práticas biomédicas, reduzindo a interlocução com as práticas tradicionais ao plano da complementariedade (LANGDON e DIEHL, 2007; LORENZO, 2011; RAYMUNDO, 2013; PERUZZO, 2016).

No Xingu, a falta de conhecimentos teóricos prévios e também de suporte faz com que o conhecimento sobre o outro seja construído pelo profissional ao longo da vivência da relação intercultural. A qualidade da relação também fica subordinada à 
capacidade pessoal de cada profissional de desenvolver relações empáticas, respeitosas e dialógicas. A força dos estereótipos e concepções prévias também denuncia a dificuldade enfrentada pelos profissionais para se desvencilharem do etnocentrismo. A interlocução com as práticas tradicionais foi pouco expressa pelos participantes da pesquisa. Alguns deles citaram interlocução com especialistas tradicionais como uma estratégia de enfrentamento das dificuldades técnicas e para adquirir maior segurança no trabalho.

O que os profissionais enfermeiros vivenciam no trabalho no Xingu é uma experiência de desconforto permanente em que não há lugar para a plena acomodação na interlocução com o outro.

Apesar da importância das características pessoais na determinação da qualidade das relações interculturais estabelecidas no nível mais imediato, o do contato direto entre os profissionais e os indígenas, é necessário considerar que o alcance do diálogo intercultural almejado na Política Nacional de Atenção à Saúde dos Povos Indígenas extrapola a dimensão individual.

Para Albó (2004), apesar da base fundamental das relações interculturais se constituírem de relações entre pessoas (nível individual) ou grupo de pessoas (nível grupal), o alcance da relação intercultural positiva de forma mais ampla se dá na articulação com uma terceira dimensão que é a estrutural representada pelas instituições e pelas estruturas sociais.

Essa dimensão estrutural colocada por Albó remete ao histórico das relações entre os Estado brasileiro e os povos indígenas. O esforço permanente para se impor aos indígenas uma posição de inferioridade nessa relação, faz com que em todos os espaços, inclusive na saúde, a relação intercultural seja marcada pela assimetria e esteja mais próxima da subjugação e da imposição do que do respeito à diferença.

$\mathrm{Na}$ saúde indígena, os DSEl também podem ser entendidos como parte da dimensão estrutural interferindo na qualidade das relações interculturais estabelecidas dentro do território. A aparente ausência do DSEI Xingu e a dificuldade em cumprir seu papel como formador e norteador também influencia a vivência da interculturalidade pelos profissionais que atuam dentro de área, 
posicionando a relação estabelecida entre indígenas e não indígenas para mais ou menos distante do desejado no modelo de atenção proposto. 
CONSIDERAÇÕES FINAIS 


\section{5 - CONSIDERAÇÕS FINAIS}

A realização do estudo permitiu evidenciar a potencialidade da vivência do trabalho como um espaço de formação e de desenvolvimento de competências para os profissionais enfermeiros que atuam no território do Parque Indígena do Xingu. Isso se tornou possível por meio da análise da trajetória percorrida por estes profissionais a partir da inserção no trabalho. Da análise dos conteúdos das entrevistas foram destacados um conjunto de temas que se inter-relacionam e que dão a dimensão concreta da experiência vivenciada pelos profissionais no trabalho, incluindo a forma como eles vão construindo e adequando a sua prática profissional em busca de uma atuação mais qualificada e adequada ao contexto do trabalho.

A inserção no trabalho em saúde no Parque Indígena do Xingu configurou-se como resultado de um conjunto de fatores pessoais que impulsionaram os profissionais para o trabalho neste campo. Entre eles, vale destacar o atrativo exercido pela diferença cultural e a concepção do campo de trabalho como um espaço de realização e reconhecimento profissional. Ficou explícito também que o DSEI Xingu funciona como um espaço concreto de absorção de profissionais na região, refletindo as dificuldades enfrentadas na profissão no que diz respeito à oferta de trabalho e remuneração. Em meio a desejos e expectativas, os profissionais também carregam em suas bagagens um imaginário acerca do que irão vivenciar no trabalho. Este imaginário é composto por um conjunto suposições sobre as características do trabalho, da atuação profissional e sobre os indígenas.

Já no primeiro contato com a realidade do trabalho, os contrastes entre o imaginário e o real aproximam os profissionais das particularidades do contexto. Contudo, é a partir da imersão, característica marcante do trabalho nesta terra indígena, que os profissionais efetivam a vivência da relação com a alteridade e se deparam com os desafios colocados para o trabalho em saúde no contexto de interculturalidade. 0 estranhamento, o confronto com o novo e a necessidade de aprender são uma constante e movem a dinâmica de interação com a diferença, não havendo lugar para acomodação.

$\mathrm{Na}$ vivência desta dinâmica pelos enfermeiros que integram as EMSI, surpresas e desafios são pontos comuns que unem as experiências singulares de encontro com 
a diferença. O comportamento ativo e acolhedor dos indígenas, a atuação qualificada e efetiva dos profissionais indígenas de saúde e a presença do enfermeiro sempre à frente do trabalho da equipe, atuando de forma solitária e desempenhando tarefas técnicas diversas, surpreendem a todos. São imagens que contrastam com os estereótipos e representações sobre os indígenas, com as referências da formação acadêmica e com o imaginário elaborado pelos profissionais antes da inserção no trabalho. As demandas técnicas figuram como o maior desafio enfrentado no início do trabalho gerando insegurança. As novas condições de trabalho e de vida também são desafiadoras para os profissionais.

Pouco a pouco as habilidades, atitudes e conhecimentos necessários para uma atuação profissional competente vão sendo identificados, impelindo os profissionais a buscar recursos que qualifiquem sua prática e os auxiliem a dar conta das demandas a serem enfrentadas.

O caráter singular da vivência se estende ao processo de aprendizado e ao desenvolvimento de competências. Apesar disso, há um conjunto de características comuns às experiências de cada profissional. As trajetórias explicitaram o quanto o aprendizado se desenvolve de forma processual, intrínseco ao trabalho no território e bastante dirigido pelos próprios profissionais. A importância dos conteúdos a serem apreendidos e a postura proativa dos profissionais na busca pelo conhecimento configuram uma experiência de aprendizado significativo que é a base para a qualificação profissional.

Dentro da área indígena, os enfermeiros vivenciam uma experiência solitária de aprendizado pessoal e profissional forjado a partir da vivência. Se o território do trabalho se consolida como lugar do aprendizado, é dele também que derivam os recursos utilizados pelos profissionais em busca de uma melhor qualificação para o trabalho. A experiência acumulada pelos profissionais já inseridos no trabalho é muito valorizada, legitimando um conjunto de práticas e atitudes consideradas adequadas e que passam a serem reproduzidas pelos recém-ingressos. Os indígenas cumprem o papel de porta voz da cultura, modos e práticas de cada etnia. Os profissionais indígenas de saúde também colaboram com o aprendizado técnico e também na mediação de conflitos que surgem no trabalho. A interlocução com os especialistas tradicionais, embora pouco citada, se desenrolou mais como uma fonte 
estratégica de segurança frente às demandas técnicas, do que propriamente uma iniciativa de articulação com as práticas tradicionais. Todas as atividades do trabalho e da vida diária que propiciam reflexão e interlocução com outros profissionais, bem como a aproximação com os indígenas constituem espaços importantes de aprendizado.

Os profissionais reconhecem o caráter contínuo do aprendizado propiciado pelo trabalho, acarretando um maior entendimento do contexto, segurança para o trabalho e modificações em suas práticas. Após alguns anos de trabalho, os profissionais consideram-se mais capacitados e com uma atuação profissional mais congruente com o contexto. Apesar disso, o perfil de atuação profissional ainda permanece pouco claro para os enfermeiros.

A partir da experiência, os enfermeiros caracterizaram o seu trabalho dentro da terra indígena como uma prática diferente, desafiadora, autônoma e, muitas vezes, solitária. Sobre os indígenas, a vivência parece não ter sido capaz de modificar concepções e representações trazidas pelos profissionais. Descritos como pessoas simples, humildes, presas às suas culturas e que conseguem ser felizes com muito pouco, nas concepções dos profissionais, os indígenas permanecem presos ao estigma da falta.

O perfil da atuação dos enfermeiros é desenhado, em parte, pelas particularidades do território e da organização do serviço proposta pelo DSEI. Assim, escala de trabalho, demandas de saúde do território, rotinas do serviço, dispersão geográfica, estrutura e composição das EMSI são fatores que colaboram para o desenho da prática e do perfil de atuação profissional.

Contudo, o saber fazer e saber ser que compõem a competência profissional são estabelecidos dentro do território. Dentre os elementos que compõe uma atuação profissional competente neste contexto, destacam-se o domínio de habilidades técnicas, a capacidade de atuar em equipe e se relacionar cotidianamente com os demais profissionais, bem como a aquisição de conhecimento sobre os povos com os quais trabalha. São habilidades, conhecimentos e atitudes adquiridos e desenvolvidos por meio da vivência do trabalho. 
Ainda sobre a competência para o trabalho, a escuta diferenciada e o relativismo cultural são atitudes exigidas aos profissionais como garantia para que a interlocução com os indígenas e suas práticas ocorra de forma dialógica e respeitosa, congruente com o modelo assistencial proposto na PNASPI. Contudo, a realidade do trabalho dentro da terra indígena demonstrou que o alcance do diálogo intercultural proposto não depende somente da relação entre os profissionais e os indígenas. Para além dessa dimensão individual, a qualidade das relações interculturais também são influenciadas pela atuação da gestão do DSEI.

A interculturalidade se firma como caráter inerente ao contexto do trabalho e sua vivência é intensificada pela imersão no trabalho.

Ficou evidente que no DSEI Xingu não há estratégias sistemáticas de acompanhamento dos profissionais e do trabalho dentro do território e que a gestão tem dificuldade em cumprir o seu papel de acolher, nortear o trabalho e formar recursos humanos, conforme colocado na PNASP. Embora a reprodução de práticas e atitudes configure um meio legítimo de aprendizado, no Xingu ela se torna perigosa, na medida em que é adotada como o principal recurso que norteia a prática profissional do enfermeiro.

A imersão e a falta de acompanhamento do trabalho fazem com que todo o aprendizado dos profissionais seja bastante autônomo, estando mais submetido às normatizações instituídas dentro do território. O caráter autônomo do aprendizado extrapola os pressupostos das metodologias ativas de ensino e aprendizagem.

A falta de acolhimento, suporte e orientação por parte do DSEI são uma constante no percurso dos profissionais, desde a inserção no trabalho. Como resultado, o DSEI parece não ser uma referência imediata para os profissionais enfermeiros no que diz respeito ao direcionamento do trabalho, da atuação profissional e da formação. É premente a necessidade de uma maior aproximação do DSEI com o trabalho dentro do território, bem como a elaboração de estratégias mais sistemáticas de acolhimento, acompanhamento no trabalho e formação.

Conhecer o percurso realizado pelos profissionais enfermeiros a partir da inserção no trabalho em saúde no Parque Indígena do Xingu permitiu ir além das questões relacionadas ao aprendizado e ao desenvolvimento de competências trazendo à 
tona pontos relevantes sobre 0 trabalho em saúde em contextos de interculturalidade. A análise sobre a vivência desses profissionais tem muito a colaborar no desenvolvimento de estratégias de formação e organização do trabalho, bem como na construção de um perfil de atuação para os enfermeiros, que são hoje uma força de trabalho muito expressiva na saúde indígena. Assim, podem subsidiar iniciativas e estratégias no DSEI Xingu, nos demais DSEl e também em outros contextos de interculturalidade. 


\section{REFERÊNCIAS}

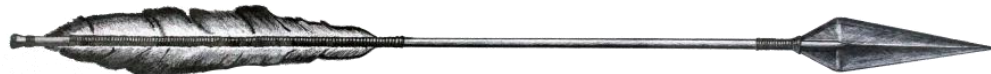




\section{6 - REFERÊNCIAS}

ALBÓ, Xavier. Interculturalidad y salud. In: JUÁREZ, G. F. (Coord.). Salud e Interculturalidad en América latina: perspectivas antropológicas. Quito: Abya-Yala, 2004. p. 65-74.

ALMEIDA, Maria. C. P. de; MELLO, Débora. F. de; NEVES, Lis. A. de. S. O trabalho de enfermagem e sua articulação com o processo de trabalho em saúde coletiva: rede básica de saúde em Ribeirão Preto. Revista Brasileira de Enfermagem, Brasília, v. 44, n. 2, p. 64 -75, 1991. Disponível em:

$<$ http://www.scielo.br/pdf/reben/v44n2-3/v44n2-3a09.pdf>. Acesso em: 20 nov. 2016.

ARAÚJO, Dolores. Noção de competência e organização curricular. Revista Baiana de Saúde Pública, Salvador, v. 31, p. 32-43, jun. 2007. Suplemento 1. Disponível em: <bhttp://inseer.ibict.br/rbsp/index.php/rbsp/article/viewFile/1422/1059>. Acesso em 10 jan. 2017.

ARROYO, M. G. Escola e trabalho: desafios e oportunidades na construção de uma política pública de formação profissional em saúde. 1 Fórum Nacional do PROFAE. Construindo uma política pública de formação profissional em saúde, Brasília, p. 64-80, 2002.

ARRUDA, Rinaldo. S. Os dilemas da relação intercultural: limites da autonomia indígena para o estabelecimento de um verdadeiro diálogo. In: DANTAS, Sylvia. D.

(Org.). Diálogos Interculturais: reflexões interdisciplinares e intervenções psicossociais. São Paulo: IEA-USP, 2012. p.161-168.

ARRUDA, Rinaldo. S. A noção de cultura e o campo da saúde indígena. São Paulo: UNIFESP, 2015. Texto de Apoio, Disciplina de Antropologia, Curso de Especialização em Saúde Indígena à distância - UAB/UNIFESP. Acesso restrito.

ATHIAS, Renato; MACHADO, Marina. A saúde indígena no processo de implantação dos Distritos Sanitários: temas críticos e propostas para um diálogo interdisciplinar. Cadernos de Saúde Pública, Rio de Janeiro, v. 17, n. 2, p. 425-431, 2001. Disponível em: <http://scielo.br/pdf/csp/v17n2/4187.pdf>. Acesso em: 15 out. 2015.

BANIWA, Gersem. Educação escolar indígena no Brasil: avanços, limites e novas perspectivas. In: Reunião Nacional da ANPED, 36., 2013 Goiânia. Trabalhos encomendados... Rio de Janeiro: ANPED, 2013. Disponível em: $<$ http://36reuniao.anped.org.br/pdfs trabalhos encomendados/gt21 trabalhoencome ndado gersem.pdf>. Acesso: 20 dez. 2015.

BARDIN, Lawrence. Análise de conteúdo. São Paulo: Edições 70, 2016.

BARRENNE, Maria E. I; ZUÑIGA, Fernando V. Competência profissional: manual de conceitos, métodos e aplicações no setor de saúde. Tradução Hiloko Ogihara Marins. Rio de Janeiro: Senac Nacional, 2004, 296p. 
BARUZZI, Roberto G. Do Araguaia ao Xingu. In: BARUZZI, Roberto. G.; JUNQUEIRA, Carmem. (Org.). Parque Indígena do Xingu: saúde, cultura e história. São Paulo: Terra Virgem, 2005. p. 59-112.

BARUZZI, Roberto G. A Universidade na Atenção à Saúde dos Povos Indígenas: a experiência do Projeto Xingu da Universidade Federal de São Paulo/Escola Paulista de Medicina. Saúde e Sociedade, São Paulo, v.16, n. 2, p.182-186, 2007.

Disponível em: < http://www.scielo.br/pdf/sausoc/v16n2/19.pdf>. Acesso em: 5 dez. 2015.

BATISTA, Karina. B. C; GONÇALVES, Otília. S. J. Formação dos profissionais de saúde para o SUS: significado e cuidado. Saúde e Sociedade, São Paulo v. 20, n. 4, p. 884-899, 2011. Disponível em: < http://www.scielo.br/pdf/sausoc/v20n4/07.pdf>. Acesso em: 15 nov. 2016.

BELLAGUARDA, Maria L. R. et al. Reflexão sobre a legitimidade da autonomia da enfermagem no campo das profissões de saúde à luz das ideias de Eliot

Freidson. Escola Anna Nery Revista de Enfermagem, v. 17, n. 2, p. 369-374, 2013. Disponível em: <http://www.redalyc.org/pdf/1277/127728367023.pdf>. Acesso em: 10 jan. 2017.

BERTOLANI, Marlon. N. Representações sociais da saúde e políticas de saúde voltadas a populações indígenas: uma análise da relação entre o sistema de saúde Guarani e a biomedicina, 2008. 183 p. Dissertação (Mestrado em Política Social) - Universidade Federal do Espírito Santo, vitória, 2008.

BERTOLANI, Marlon. N.; LEITE, Izildo. C. O Respeito à Diferença: contribuições da Teoria das Representações Sociais para as políticas de saúde voltadas a populações indígenas. Revista de Políticas Públicas, São Luís, v. 13, n. 2, p. 291 301, 2009. Disponível em:

<http://www.periodicoseletronicos.ufma.br/index.php/rppublica/article/view/27>. Acesso em: 15 out. 2015.

BRASIL. Ministério da Saúde. Conferência Nacional de Proteção à Saúde do Índio. Brasília, DF, 1986.

BRASIL. Lei n 9394 de 20 de dezembro de 1996. Estabelece as diretrizes e bases da educação nacional. Diário Oficial da União, Brasília, DF, 23 dez. 1996. Seção 1, p. 27833. Disponível em: <http://www.planalto.gov.br/ccivil_03/LEIS/L9394.htm>. Acesso em: 15 out. 2015.

BRASIL. Lei $n^{\circ}$ 9836, de 23 de setembro de 1999. Dispõe sobre as condições para a promoção, proteção e recuperação da saúde, a organização e o funcionamento dos serviços correspondentes e dá outras providências, instituindo o Subsistema de Atenção à Saúde Indígena. Diário Oficial da União, Brasília, DF, 24 set. 1999. Seção 1, p.1. Disponível em <http://www.planalto.gov.br/ccivil 03/leis/l9836.htm>. Acesso: 10 jul. 2015.

BRASIL. Ministério da Saúde. Secretaria de Gestão do Trabalho e da Educação em Saúde. Departamento de Gestão da Educação na Saúde. Política de educação e desenvolvimento para o SUS: caminhos para a Educação Permanente em Saúde - Pólos de Educação Permanente em Saúde. Brasília, DF, 2004a. 
BRASIL. Ministério da Saúde. Secretaria executiva. Núcleo técnico da Política Nacional de Humanização. Política Nacional de Humanização: a humanização como eixo norteador das práticas de atenção e gestão em todas as instâncias do SUS. Brasília, DF, 2004b. Série B. Textos básicos de saúde. Disponível em: $<$ http://www.saude.sp.gov.br/resources/humanizacao/biblioteca/pnh/pnh.pdf > Acesso em: 15 nov. 2016.

BRASIL. Ministério da Saúde. Secretaria de Gestão do Trabalho e da Educação na Saúde. Departamento de Gestão da Educação na Saúde. A Educação Permanente entra na roda: polos de educação permanente em saúde. Brasília, DF, 2005.

BRASIL. Ministério da Saúde. Gabinete do ministro. Portaria n 1996, de 20 de agosto de 2007. Dispõe sobre as diretrizes para a implementação da Política Nacional de Educação Permanente em saúde. Diário Oficial da União, Brasília, DF, 22 ago. 2007. Seção 1. Disponível em:

<http://bvsms.saude.gov.br/bvs/saudelegis/gm/2007/prt1996 2008 2007.html >. Acesso em: 30 ago. 2015.

BRASIL. Ministério da Saúde. Secretaria executiva coordenação geral de inovação gerencial. Estrutura regimental do Ministério da Saúde decreto $n^{\circ} 7.336$ de 19 de outubro de 2010. Brasília, DF, 2011. Série E. Legislação em saúde. Disponível em:

$<$ http://bvsms.saude.gov.br/bvs/publicacoes/estrutura regimental ms decreto 7336 . pdf>. Acesso em: 10 jun. 2015

BRASIL. Ministério da Saúde. Secretaria de atenção à Saúde. Departamento de Atenção Básica. Política Nacional de Atenção Básica. Brasília, DF, 2012. Série E. Legislação em saúde. Disponível em:

$<$ http://189.28.128.100/dab/docs/publicacoes/geral/pnab.pdf $>$. Acesso em 15 nov. 2016.

BRASIL. Ministério da Saúde. Secretaria de Gestão do Trabalho e da Educação na Saúde. Programa mais Médicos dois anos: mais saúde para a população. Brasília, DF: Ministério da Saúde, 2015a.

BRASIL. Ministério da Saúde. Secretaria de vigilância em saúde. Boletim epidemiológico 46 n. 10 - indicadores de vigilância em saúde, analisados segundo a variável raça/cor. Brasília, DF, 2015b. Disponível em: $<$ http://portalsaude.saude.gov.br/images/pdf/2015/abril/22/Boletim-raca-cor-09-0415-v2.pdf>. Acesso em: 03 out. 2015.

CAMELO, Silvia. H. H; ANGERAMI, Emília. L. S. Competência profissional: a construção de conceitos, estratégias desenvolvidas pelos serviços de saúde e implicações para a enfermagem. Texto e Contexto Enfermagem, Florianópolis, v.22, n. 2, p. 552-560, abr./jun. 2013. Disponível em: $<$ http://www.redalyc.org/html/714/71427998034/>. Acesso em: 5 jan. 2017.

CARDOSO, Andrey. M.; SANTOS, Ricardo. V.; COIMBRA JR, Carlos. E. A. Políticas públicas em saúde para os povos indígenas. In: BARROS, Denise. C; OLIVEIRA e SILVA, Denise; GUGELMIN, Silvia. A. (Org.). Vigilância Alimentar e Nutricional para a Saúde Indígena. Rio de Janeiro: Fiocruz, 2007. p. 75-91.

CARDOSO, Marina D. Políticas de saúde indígena no Brasil: do modelo assistencial à representação política. In: LANGDON, Esther Jean; CARDOSO, Marina. D. (Org.). 
Saúde Indígena: Políticas comparadas na América latina. Florianópolis: UFSC, 2015. p. 83-106.

CECCIM, Ricardo. B. Desenvolvimento de competências no trabalho em saúde: educação, áreas de conhecimento e profissões no caso da saúde. Revista Tempus Actas de Saúde Coletiva, v.6, n.2 p. 253-277, 2012. Disponível em: $<$ http://www.tempusactas.unb.br/index.php/tempus/article/view/1128/1041>. Acesso em: 15 jan. 2017.

CECCIM, Ricardo. B.; FERLA, Antônio. A. Educação permanente em saúde. In: PEREIRA, Isabel. B.; LIMA, Júlio. C. F (Org.). Dicionário da educação profissional em saúde. 2. ed. Rio de Janeiro: Escola Politécnica de saúde Joaquim Venâncio, 2008, p. 162-168.

CHIESA, Anna. M. et al. A formação de profissionais da saúde: aprendizagem significativa à luz da promoção da saúde. Cogitare Enfermagem, Curitiba, v.12, n. 2, p. 236-240, 2007. Disponível em: $<$ http://revistas.ufpr.br/cogitare/article/view/9829>. Acesso em: 28 fev. 2017.

CIAMPONE, Maria Helena Trench; PEDUZZI, Marina. Trabalho em equipe e trabalho em grupo no programa de saúde da família. Revista Brasileira de Enfermagem, Brasília, v. 53, p. 143-147, 2000. Número especial. Disponível em: $<$ http://www.scielo.br/scielo.php?script=sci_arttext\&pid=S0034-

$71672000000700024 \& \operatorname{lng}=e n \& n r m=i s o>$. Acesso em: 15 dez. 2016.

CIMI. CONSELHO INDIGENISTA MISSIONÁRIO. A violência contra os povos indígenas no Brasil dados de 2012. Brasília, DF, 2013a. Disponível em: $<$ http://www.cimi.org.br/pub/viol/viol2012.pdf >. Acesso em: 20 jun. 2015

CIMI - CONSELHO INDIGENISTA MISSIONÁRIO. Política de atenção à saúde indígena no Brasil: breve recuperação histórica sobre a política de assistência à saúde nas comunidades indígenas. Brasília, DF, 2013b. Disponível em: $<$ http://6ccr.pgr.mpf.mp.br/institucional/grupos-de-trabalho/saude/cartilha-sobresaude-indigena-cimi>. Acesso em: 15 jun. 2015.

CIMI - CONSELHO INDIGENISTA MISSIONÁRIO. A violência contra os povos indígenas no Brasil dados de 2013. Brasília, DF, 2014. Disponível em: $<$ http://www.cimi.org.br/pub/Relatviolenciadado2013.pdf>. Acesso em: 20 maio. 2015.

CIMI -CONSELHO INDIGENISTA MISSIONÁRIO._A violência contra os povos indígenas no Brasil dados de 2014. Brasília, DF, 2015. Disponível em: $<$ http://www.cimi.org.br/pub/Arquivos/Relat.pdf>. Acesso em: 20 maio. 2015.

COIMBRA JR, Carlos. J. E. A. Saúde e povos indígenas no Brasil: reflexões a partir do I Inquérito Nacional de Saúde e Nutrição Indígena. Cadernos de Saúde Pública, Rio de Janeiro, v. 30, n. 4, p. 855-9, 2014. Disponível em: <http://www.scielo.br/pdf/csp/v30n4/0102-311X-csp-30-4-0855.pdf>. Acesso em: 20 maio. 2015.

COIMBRA JR, Carlos. E. A.; SANTOS, Ricardo. V. Saúde, minorias e desigualdade: algumas teias de inter-relações, com ênfase nos povos indígenas no Brasil. Ciência e Saúde Coletiva, Rio de Janeiro, v. 5, n. 1, p. 125-132, 2000. Disponível em: $<$ http://www.scielo.br/pdf/csc/v5n1/7084.pdf>. Acesso em: 15 abr. 2015. 
COIMBRA JR, Carlos. E. A.; SANTOS, Ricardo. V. Cenários e tendências da saúde e da epidemiologia dos povos indígenas no Brasil. In: COIMBRA JR, Carlos. E. A.; SANTOS, Ricardo. V; ESCOBAR, Ana lúcia. (Org.). Epidemiologia e saúde dos povos indígenas no Brasil. Rio de janeiro: FIOCRUZ/ABRASCO, 2003, p. 13-48.

COIMBRA JR, Carlos. E. A.; SANTOS, Ricardo. V.; CARDOSO, Andrey.

M. Processo saúde-doença. In: BARROS, Denise. C; OLIVEIRA e SILVA, Denise; GUGELMIN, Silvia. A. (Org.). Vigilância Alimentar e Nutricional para a Saúde Indígena. Rio de Janeiro: Fiocruz, 2007. p. 47-74.

CONFALONIERI, Ulisses E.C. O Sistema Único de Saúde e as populações indígenas: por uma integração diferenciada. Cadernos de Saúde Pública, Rio de Janeiro, v. 5, n. 4, p. 441-450, 1989. Disponível em: < http://www.scielo.br/pdf/csp/v5n4/08.pdf>. Acesso em: 20 maio. 2015.

CONTERNO, Solange. F.R; LOPES, Roseli. E. Inovações do século passado: origens dos referenciais pedagógicos na formação profissional. Trabalho, Educação e Saúde, Rio de Janeiro, v. 11, n. 3, p. 503-523, 2013. Disponível em: <http://www.scielo.br/pdf/tes/v11n3/v11n3a04.pdf>. Acesso em: 10 fev. 2017.

COSTA, Dina. C. Política indigenista e assistência à saúde: Noel Nutels e o serviço de unidades sanitárias aéreas. Cadernos de Saúde Pública, Rio de Janeiro, v. 3, n. 4, p. 388-340, 1987. Disponível em: <http://www.scielo.br/pdf/csp/v3n4/v3n4a03.pdf>. Acesso em: 22 maio. 2015.

DE MATTOS CORRÊA, Ludmilla Zangali; DOS SANTOS, Neuci Cunha; KOBI, Mirian Costa Barbosa. Expansão dos cursos de graduação em enfermagem em Mato Grosso: implicações e desafios. Revista Eletrônica de Enfermagem, v. 16, n. 4, p. 744-753, 2014. Disponível em:

<https://www.fen.ufg.br/fen_revista/v16/n4/pdf/v16n4a06.pdf>. Acesso em: 30 jun. 2017.

DEL CURA, M. L. A; RODRIGUES, A. R. F. Satisfação profissional do enfermeiro. Revista Latino Americana de Enfermagem, Ribeirão Preto, v. 7, n. 4, p. 21-28, 1999. Disponível em: <http://www.revistas.usp.br/rlae/article/view/1388>. Acesso em: 12 jan. 2017.

DELUIZ, Neise. O modelo das competências profissionais no mundo do trabalho e na educação: implicações para o currículo. Boletim técnico do SENAC, Rio de Janeiro, v. 27, n. 3, p 13-24, 2001a. Disponível em: $<$ http://www.bahiana.edu.br/CMS/Uploads/O\%20modelo\%20das\%20competencias\% 20profissionais\%20N Deluiz.pdf>. Acesso em: 20 jan. 2017.

DELUIZ, Neise. Qualificação, competências e certificação: visão do mundo do trabalho. In: Ministério da Saúde. Secretaria de gestão de investimentos em saúde. Formação, n. 2, Brasília: 2001b, p. 5-15. Disponível em: <http://bvsms.saude.gov.br/bvs/publicacoes/profae/Revista2002.pdf>. Acesso em 20 jan. 2017.

DIBBITS, Ineke. A interculturalidade deve apontara para atitude de assumir positivamente a situação de diversidade cultural. Rio de Janeiro, Revista RETS, $n$. 6, abr./maio./jun. 2010. Entrevista concedida a Ana Beatriz de Noronha. Disponível em: <http://www.epsjv.fiocruz.br/noticias/entrevista/a-interculturalidade-deve-apontar-para-aatitude-de-assumir-positivamente-a>. b Acesso em: 20 out. 2016. 
DIEHL, Eliana. E; LANGDON, Esther Jean; SCOPEL, Raquel. P.D. Contribuição dos agentes indígenas de saúde na atenção diferenciada à saúde dos povos indígenas brasileiros. Cadernos de Saúde Pública, Rio de Janeiro, v. 28, n. 5, p. 819-831, 2012. Disponível em:

$<$ https://www.researchgate.net/profile/Esther Jean Langdon/publication/225069271 The contribution of indigenous community health workers to special healthcare for Brazilian indigenous peoples/links/0f31752fd04e3202f1000000.pdf >. Acesso em: 20 jan. 2016.

DIEHL, Eliana. E; PELLEGRINI, Marcos. A. Saúde e povos indígenas no Brasil: o desafio da formação e educação permanente de trabalhadores para atuação em contextos interculturais. Cadernos de Saúde Pública, Rio de Janeiro, v. 30, n. 4, p. 867-874, 2014. Disponível em: <http://www.scielo.br/pdf/csp/v30n4/0102-311X-csp30-4-0867.pdf>. Acesso em: 20 out. 2015.

DUMÊT FERNANDES, Josicélia et al. Expansão da educação superior no Brasil: ampliação dos cursos de graduação em enfermagem. Revista Latino Americana de Enfermagem, Ribeirão Preto, v. 21, n. 3, p. 670-678, 2013. Disponível em: <http://www.revistas.usp.br/rlae/article/view/75972/79503 >. Acesso em: 30 jun. 2017.

EPM- Escola Paulista de Medicina. Departamento de Medicina Preventiva. Proposta para o plano de saúde a ser implantado no Parque Nacional do Xingu. São Paulo: EPM, 1983. 20 p.

EPM- Escola Paulista de Medicina. Departamento de Medicina Preventiva. Proposta para o plano de saúde a ser implantado no Parque Nacional do Xingu. São Paulo: EPM, 1987. 32 p.

EPM- Escola Paulista de Medicina, Unidade de Saúde e Meio Ambiente. Avaliação das atividades do projeto de atenção à saúde das comunidades do Parque Indígena do Xingu pela Unidade de Saúde e Meio ambiente setembro de 1992 a janeiro de 1994. São Paulo: EPM, 1994. 32 p.

EPM- Escola Paulista de Medicina. Unidade de Saúde e Meio Ambiente. 30 anos Xingu: relatório de atividades da unidade de Saúde e Meio ambiente no Parque Indígena do Xingu, 1995. São Paulo: UNIFESP, 1996.

FALKENBERG, Mirian Benites. Representações sociais do cuidado entre trabalhadores que atuam em contextos de interculturalidade na atenção à saúde indígena. 2014. 146 f. Dissertação (Mestrado em Saúde Coletiva) Universidade de Brasília, Brasília, 2014.

FELIX, F. A; NAVARRO, E. C. Habilidades e competências: novos saberes educacionais e a postura do professor. Revista Interdisciplinar, v.2, n. 2, 2009. Disponível em: $<$ http://revista.univar.edu.br/index.php/interdisciplinar/article/view/238>. Acesso em 15 jan. 2017.

FERNANDES, Maria. N. de F. Representações sociais sobre a prática do cuidado para enfermeiros da saúde indígena: um estudo transcultural. 2010.118 p. Dissertação (Mestrado em Ciências da Saúde) - Universidade Federal do Rio Grande do Norte, Natal, 2010. 
FERREIRA, Luciana. B.; PORTILLO, Jorge Alberto. C.; DO NASCIMENTO, Wanderson. F. A Criação da Secretaria Especial de Saúde Indígena. Tempus Actas de Saúde Coletiva, Brasília, DF, v. 7, n. 4, p. 83-95, 2013. Disponível em: $<$ http://tempusactas.unb.br/index.php/tempus/article/view/1419 >. Acesso em: 15 jan. 2016.

FERREIRA, Luciane. O. Os discursos oficiais e a emergência do tradicional como objeto de políticas públicas. In: Medicinas indígenas e as políticas da tradição: entre discursos oficiais e vozes indígenas. Rio de Janeiro: Fiocruz, 2013. Cap. 2, p. 49-70.

FERREIRA, Luciane. O. Interculturalidade e saúde indígena no contexto das políticas públicas brasileiras. In: LANGDON, Esther Jean; CARDOSO, Marina. D. (Org.). Saúde Indígena: Políticas comparadas na América latina. Florianópolis: UFSC, 2015. p. 217-246.

FLEURY, Maria Tereza Leme; FLEURY, Afonso. Construindo o conceito de competência. Revista de Administração contemporânea, Curitiba, v. 5, p.183-196, 2001. Número Especial. Disponível em: $<$ http://www.scielo.br/pdf/rac/v5nspe/v5nspea10.pdf>. Acesso em: 20 nov. 2016.

FRAGELLI, Thaís. B. O; SHUMIZU, Helena. E. Competências profissionais em Saúde Pública: conceitos, origens, abordagens e aplicações. Revista Brasileira de enfermagem, Brasília, v. 65, n. 4, p. 667-674, jul./ago. 2012. Disponível em: $<$ http://www.scielo.br/pdf/reben/v65n4/a17v65n4.pdf>. Acesso em: 10 jan. 2017.

FUNAI. FUNDAÇÃO NACIONAL DO ÍNDIO. Povos Indígenas Isolados e de Recente Contato. Brasília, DF, [s.d.]. Disponível em: $<$ http://www.funai.gov.br/index.php/nossas-acoes/povos-indigenas-isolados-e-derecente-contato $>$. Acesso em: 15 ago. 2015.

FUNASA - Fundação Nacional de Saúde. 2ª Conferência Nacional de Saúde indígena: relatório final. Brasília, DF, 1993.

FUNASA - Fundação Nacional de Saúde. 3a Conferência Nacional de Saúde Indígena: relatório final. Brasília, DF, 2001.

FUNASA - Fundação Nacional de Saúde. Política Nacional de Atenção à Saúde dos Povos Indígenas. Brasília, DF, 2002.

FUNASA - Fundação Nacional de Saúde. 4a Conferência Nacional de Saúde Indígena: relatório final. Brasília, DF, 2007.

FUNASA - Fundação Nacional de Saúde. Vigilância em Saúde Indígena: síntese dos indicadores 2010. Brasília, DF, 2010.

GARNELO, Luiza. Política de Saúde Indígena no Brasil: notas sobre as tendências atuais do processo de implantação do subsistema de atenção à saúde. In:

GARNELO, Luiza; PONTES, Ana Lúcia. (Org.). Saúde indígena: uma introdução ao tema. Brasília: MEC-SECADI, 2012. p. 18-59.

GARNELO, Luiza; BUCHILLET, Dominique. Taxonomias das doenças entre os índios Baniwa (Arawak) e Desana (Tukano oriental) do Alto Rio Negro (Brasil). Horizontes Antropológicos, Porto Alegre, v. 12, n. 26, p. 231-260, 2006. 
Disponível em: <http://www.scielo.br/pdf/ha/v12n26/a10v1226.pdf>. Acesso em: 10 jan. 2016.

GIMENO, Suely. G. A. et al. Perfil metabólico e antropométrico de índios Aruák, Mehináku, Waurá e Yawalapití, Alto Xingu, Brasil Central, 2000/2002. Cadernos de Saúde Pública, Rio de Janeiro, v. 23, n. 8, p. 1946-54, 2007. Disponível em: $<$ http://www.scielo.br/pdf/csp/v23n8/21.pdf $>$. Acesso em: 10 jan. 2016.

GOMES, Antônio. M. T; OLIVEIRA, Denize. C. Estudo da estrutura da representação social da autonomia profissional em enfermagem. Revista da Escola de Enfermagem USP, São Paulo, v. 39, n. 2, p. 145-153, 2005a. Disponível em: $<$ http://www.ee.usp.br/reeusp/upload/pdf/17.pdf>. Acesso em: 15 jan. 2017.

GOMES, Antônio. M. T; OLIVEIRA, Denize. C. Representação social da autonomia profissional do enfermeiro na saúde pública. Revista Brasileira de Enfermagem, Brasília, v. 58, n. 4, p. 393-395, 2005b. Disponível em: <http://www.scielo.br/pdf/reben/v58n4/a03v58n4.pdf>. Acesso em: 15 jan. 2017.

GOMES, Mércio. P. Os índios e o Brasil: passado, presente e futuro. São Paulo: Contexto, 2012.

GONÇALVES, Ricardo. B. M. Prática de saúde: processos de trabalho e necessidades. São Paulo: Cefor,1992. 53p.

HAUSMANN, Mônica; PEDUZZI, Marina. Articulação entre as dimensões gerencial e assistencial do processo de trabalho do enfermeiro. Texto Contexto Enfermagem, Florianópolis, v.18, n. 2, p. 258-265, 2009. Disponível em: $<$ http://www.scielo.br/pdf/tce/v18n2/08>. Acesso em: 15 jan. 2017.

HORIBA, N. M. de Souza. Um olhar da enfermagem à saúde no Distrito Sanitário Especial Indígena do Alto Rio Negro. 2012. 75 p. Dissertação (Mestrado em Educação Profissional em Saúde) - Escola Politécnica de Saúde Joaquim Venâncio, Fundação Oswaldo Cruz, Rio de Janeiro, 2012.

IBGE - INSTITUTO BRASILEIRO DE GEOGRAFIA E ESTATÍ́STICA. Censo Demográfico 2010. Características gerais dos indígenas, resultados do universo. Rio de Janeiro, 2010. Disponível em:

$<$ http://www.ibge.gov.br/home/estatistica/populacao/censo2010/default resultados u niverso.shtm>. Acesso em: 20 maio. 2015.

IDS-SSL-CEBRAP - INSTITUTE OF DEVELOPEMENT STUDIES - SAÚDE SEM LIMITES - CENTRO BRASILEIRO DE ANÁLISE E PLANEJAMENTO. Diagnóstico situacional do Subsistema de Saúde Indígena: relatório inicial (revisado). Brasília, 2009.

ISA - INSTITUTO SOCIOAMBIENTAL. Almanaque socioambiental: Parque Indígena do Xingu 50 anos. São Paulo, 2011.

ISA - INSTITUTO SOCIOAMBIENTAL. Povos indígenas no Brasil. A Fundação Nacional do índio (FUNAI). São Paulo, [s.d.a]. Disponível em:

$<$ http://pib.socioambiental.org/pt/c/politicas-indigenistas/orgao-indigenistaoficial/funai>. Acesso em: 15 set. 2015.

ISA - INSTITUTO SOCIOAMBIENTAL. Povos indígenas no Brasil. O serviço de proteção aos índios (SPI). São Paulo, [s.d.b]. Disponível em: 
$<$ http://pib.socioambiental.org/pt/c/politicas-indigenistas/orgao-indigenista-oficial/oservico-de-protecao-aos-indios-(spi)>. Acesso em: 15 set. 2015.

ISA - INSTITUTO SOCIOAMBIENTAL. Povos indígenas no Brasil. De olho nas terras indígenas no Brasil. São Paulo, [s.d.c]. Disponível em:

$<$ http://ti.socioambiental.org/pt-br/\#!/pt-br/terras-indigenas/390>. Acesso em: 15 set. 2015.

JUNQUEIRA, Carmem. Etiqueta e Sutileza no trato da questão indígena. In: Saúde Indígena: primeiro curso de atenção terciária. São Paulo: FUNASA, 2004. p. 87-94.

KAWATA, Lauren. S. et al. Atributos mobilizados pela enfermeira na saúde da família: aproximação aos desempenhos na construção da competência gerencial. Revista de Enfermagem da USP, São Paulo, v. 45, n. 2, p. 349-335, 2011. Disponível em: $<$ http://www.producao.usp.br/bitstream/handle/BDPI/2971/art KAWATA Atributos m obilizados pela enfermeira na Saude da 2011. pdf? sequence $=1$ \&isAllowed $=y>$. Acesso em 10 jan. 2017.

KRENAK, Aílton. Uma visita inesperada. Povos indígenas e tolerância: construindo práticas de respeito e solidariedade. São Paulo: Edusp, p. 71-78, 2001.

LANGDON, Esther Jean. Saúde e povos indígenas: os desafios na virada do século. In: Congreso Latinoamericano de Ciencias Sociales y Medicina, Venezuela, 5., 1999,Venezuela. Anais... Isla de Margarita, 1999. Disponível em: <http://www.antropologia.com.br/tribo/nessi/textos/Margsav.htm>. Acesso em: 10 out. 2015.

LANGDON, Esther Jean. Uma avaliação crítica da atenção diferenciada e a colaboração entre antropologia e profissionais de saúde. In: Saúde dos Povos Indígenas: reflexões sobre antropologia participativa. Rio de Janeiro: Contra Capa, 2004. p. 33-52.

LANGDON, Esther Jean. et al. A participação dos agentes indígenas de saúde nos serviços de atenção à saúde: a experiência em Santa Catarina, Brasil. Cadernos de Saúde Pública, Rio de Janeiro, v. 22, n.12, p. 2637-2646, 2006.

LANGDON, Esther Jean; DIEHL, Eliana. E. Participação e autonomia nos espaços interculturais de Saúde Indígena: reflexões a partir do sul do Brasil. Saúde e

Sociedade, São Paulo, v. 16, n. 2, p. 19-36, 2007. Disponível em: $<$ http://www.scielo.br/pdf/sausoc/v16n2/04.pdf>. Acesso em: 10 out. 2015.

LANGDON, Ester Jean; WIIK, Flávio Braune. Antropologia, saúde e doença: uma introdução ao conceito de cultura aplicado às ciências da saúde. Revista Latino Americana de Enfermagem, Ribeirão Preto, v.18, n.3, p. 173-181, maio-jun. 2010. Disponível em: <http://www.scielo.br/pdf/rlae/v18n3/pt 23>. Acesso em: $18 \mathrm{fev}$. 2017.

LIMA, Valéria. V. Competência: distintas abordagens e implicações na formação de profissionais de saúde. Interface (Botucatu), Botucatu, v. 9, n.17, p. 369-379, marago. 2005. Disponível em: <http://www.scielo.br/pdf/icse/v9n17/v9n17a12>. Acesso em: 15 nov. 2016. 
LORENZO, Cláudio. Desafios para uma bioética clínica interétnica: reflexões a partir da Política Nacional de Saúde Indígena. Revista Bioética, Brasília, DF, v. 19, n. 2, p. 329-342, 2011. Disponível em:

$<$ http://revistabioetica.cfm.org.br/index.php/revista bioetica/article/view/631 >. Acesso em 10 nov. 2017.

LOUZADA, Jaime; NETO, David Lopes. Abordagem crítico-interpretativa das fragilidades e potencialidades do trabalho de enfermagem aos ianomâmis,

Amazonas. Enfermagem em Foco, Brasília, v.1, n.2, p. 42-45, maio. 2010.

Disponível em:

$<$ http://revista.portalcofen.gov.br/index.php/enfermagem/article/view/12>. Acesso em: 15 dez. 2016.

LIMA, A. C. S. Um olhar sobre a presença das populações nativas na invenção do Brasil. In: SILVA, A. L.; GRUPIONI, L. D. B. (Org.). A questão indígena na sala de aula: novos subsídios para professores de $1^{\circ}$ e $2^{\circ}$ graus. Brasília: Ministério da Educação e Cultura, 1995. p. 407-419.

LIMA, Maria Alice. D. S; ALMEIDA, Maria. C. P. de. O trabalho de enfermagem na produção de cuidados de saúde no modelo clínico. Revista Gaúcha de

Enfermagem, Porto Alegre, v. 20, p. 86-101,1999. Número especial. Disponível em: $<$ http://www.lume.ufrgs.br/bitstream/handle/10183/23457/000265968.pdf $>$. Acesso em 15 jan. 2017.

LIMA, Valéria. V. Competência: distintas abordagens e implicações na formação de profissionais de saúde. Interface (Botucatu), Botucatu, v. 9, n. 17, p. 369-379, 2005. Disponível em: <http://www.scielo.br/pdf/icse/v9n17/v9n17a12.pdf>. Acesso em: 10 jan. 2016.

MACHADO, José Nilson. Sobre a ideia de competência. In: PERRENOUD, Philippe et al. As competências para ensinar no século XXI: formação de professores e o desafio da avaliação, Porto Alegre: Artmed, 2002, p. 137-155.

MACHADO, José Nilson. Sobre a ideia de competência. Seminários de Estudos em Epistemologia e Didática (SEED), São Paulo, ago. 2006, p.1-6. Disponível em: < http://www.nilsonjosemachado.net/20060804.pdf>. Acesso em: 20 nov. 2016.

MACKERTE, Natália. G. S; OTT, Ari. M. T. O protagonismo da enfermagem na saúde indígena: um estudo de caso no distrito Sanitário Especial Indígena Porto Velho. In: Reunião Anual da SBPC, 66., 2014, Rio Branco. Anais eletrônicos... São Paulo: SBPC/UFAC, 2014. Disponível em: <http://www.sbpcnet.org.br/livro/66ra/resumos/resumos/7638.htm>. Acesso em: 13 dez. 2016.

MARCONI, Marina de Andrade; LAKATOS, Eva Maria. Fundamentos de metodologia científica. 5. ed. São Paulo: Atlas, 2003.

MARQUES, Giselda. Q; LIMA, Maria Alice. D.S. Organização tecnológica do trabalho em um pronto atendimento e a autonomia do trabalhador de enfermagem. Revista da Escola de Enfermagem da USP, São Paulo, v. 42, n. 1, p. 41-47, 2008.

Disponível em: $<$ http://www.lume.ufrgs.br/bitstream/handle/10183/69670/000634530.pdf? sequence $=$ 1>. Acesso em 15 jan. 2017. 
MÉDICI, André. C. Estrutura e dinâmica da força de trabalho médica no Brasil na década de 70. Revista de Administração Pública, Rio de Janeiro, v.19, n. 2, p.3177, 1985. Disponível em:

<http://bibliotecadigital.fgv.br/ojs/index.php/rap/article/viewFile/10289/9280>. Acesso em: 15 dez. 2016.

MÉDICI, André. C. A força de trabalho em saúde no Brasil nos anos 70: percalços e tendências. Revista de Administração Pública, Rio de Janeiro, v.20, n. 3, p.54-69, 1986. Disponível em:

$<$ http://bibliotecadigital.fgv.br/ojs/index.php/rap/article/viewFile/10019/9021>. Acesso em: 15 dez. 2016.

MENÉNDEZ, Eduardo. L. Salud intercultural: propuestas, acciones y fracasos. Ciência e Saúde Coletiva, Rio de Janeiro, v. 21, n.1, p.109-

118, 2016. Disponível em: <http://www.scielo.br/pdf/csc/v21n1/1413-8123-csc-2101-0109.pdf >. Acesso em: 10 fev. 2017.

MENDONÇA, Sofia. B. M. de. O agente indígena de saúde no Parque Indígena do Xingu. 1996. Dissertação (Mestrado em Ciências Sociais) - Pontifícia Universidade Católica de São Paulo, São Paulo, 1996.

MENDONÇA, Sofia. B. M. de. O Agente Indígena de Saúde no Parque Indígena do Xingu: reflexões. In: BARUZZI, Roberto. G; JUNQUEIRA, Carmem. (Org.). Parque Indígena do Xingu: saúde, cultura e história. São Paulo: Terra Virgem, 2005. p. 227-246.

MENDONÇA, Sofia. B. M. de. Saúde indígena: distâncias que aproximam. In: BRASIL. Ministério da Saúde. Secretaria de Atenção à Saúde. Política Nacional de Humanização. Cadernos Humaniza SUS, v.2, Brasília, DF, 2010, p. 179-194. Série B. Textos básicos de saúde.

MENDONÇA, Sofia. B. M. de. Reflexões sobre a relação intercultural no campo da saúde indígena: uma introdução. São Paulo: UNIFESP, 2013. Texto de Apoio, Disciplina de Antropologia, Curso de Especialização em Saúde Indígena à distância - UAB/UNIFESP. Acesso restrito.

MERHY, Emerson. E. Em busca do tempo perdido: a micropolítica do trabalho vivo em ato. In: MERHI, Emerson. E; Onocko, Rosana. (Org.). Agir em saúde: um desafio para o público. São Paulo: Hucitec, 1997. p. 71-112.

MINAYO, M.C.S. (Org.); DESLANDES, S.F.; GOMES, R. Pesquisa social: teoria, método e criatividade. 33. ed. São Paulo: Editora Vozes, 2013.

MINAYO, M.C.S. O desafio do conhecimento: pesquisa qualitativa em saúde. 3. ed. São Paulo: Hucitec, 2014.

MITRE, Sandra $M$ et al. Metodologias ativas de ensino-aprendizagem na formação profissional em saúde: debates atuais. Revista Ciência e Saúde Coletiva, Rio de Janeiro, v. 13, p. 2133-2144, 2008. Suplemento 2. Disponível em:

<http://www.scielosp.org/pdf/csc/v13s2/v13s2a18. >. Acesso em: 15 jan. 2017.

MOREIRA, Marco A. Aprendizagem significativa: um conceito subjacente.

Aprendizagem Significativa em Revista, local, n. 3, v. 1, p. 25-46, 2011. 
Disponível em: <http://www.if.ufrgs.br/asr/artigos/Artigo ID15/v1 n3 a2011.pdf>. Acesso em: 25 fev. 2017.

NOGUEIRA, Roberto. P. O Trabalho em Serviços de Saúde. In: SANTANA, José. P.(Org.). Organização do Cuidado a partir de Problemas: uma alternativa metodológica para atuação da equipe de Saúde da Família. Brasília, DF: Organização Pan-Americana da Saúde, 2000. p. 59-64.

NOVO, Marina. P. Saúde e interculturalidade: a participação dos Agentes Indígenas de Saúde/AIS no alto Xingu. Revista Antropol Soc Alunos PPGAS/UFSCAR., São Paulo, v. 1, n.1, p. 122-147, 2009. Disponível em: <http://www.rau.ufscar.br/wpcontent/uploads/2015/05/r@uprimeiraedicao-artigo-6.p> Acesso em: 20 jan. 2016.

NOVO, Marina. P. Política e intermedicalidade no alto Xingu: do modelo à prática de atenção à saúde indígena. Cadernos de Saúde Pública, Rio de Janeiro, v. 27, n.7, p. 1362-1370, 2011. Disponível em: <http://www.scielo.br/pdf/csp/v27n7/11.pdf>. Acesso em: 10 jan. 2016.

OLIVEIRA, D. C. de. Análise de Conteúdo Temático-Categorial: uma proposta de sistematização. Revista de Enfermagem UERG, Rio de Janeiro, v.16, n. 4, p. 569576, 2008. Disponível em: <http://www.facenf.ueri.br/v16n4/v16n4a19.pdf>. Acesso em: 20 ago. 2016.

OLIVEIRA, Lavínia. S. S. de. Xingu (1997-2001). In: BITTENCOURT, Maria et al. Acre, Rio Negro e Xingu: a formação indígena para o trabalho em saúde. São Paulo: Associação Saúde Sem Limites, 2005a. p. 91-115.

OLIVEIRA, Lavínia. S. S. de. O Agente Indígena de Saúde no Parque Indígena do Xingu: perspectivas de formação e trabalho. In: BARUZZI, Roberto. G; JUNQUEIRA, Carmem. (Org.). Parque Indígena do Xingu: saúde, cultura e história. São Paulo: Terra Virgem, 2005b. p. 247-258.

OLIVEIRA, Lavínia. S. S. de. Um panorama sobre o trabalho e os trabalhadores da saúde indígena. São Paulo: UNIFESP, 2014. Texto de Apoio, Disciplina de Antropologia, Curso de Especialização em Saúde Indígena à distância UAB/UNIFESP. Acesso restrito.

OLIVEIRA, Maria Luiza. C. de. Análise da capacitação dos enfermeiros que atuam na atenção à saúde das populações indígenas. 2013. 136 p. Dissertação (Mestrado associado em Enfermagem) - Escola de Enfermagem de Manaus, Universidade Federal do Amazonas, Manaus, 2013.

OMS. Estrategia de la OMS sobre medicina tradicional 2002-2005. Genebra, 2002. Disponível em:

$<$ http://www.dominiopublico.gov.br/download/texto/op000023.pdf >. Acesso em: 15 nov. 2015.

PAI, Daiane Dal; SCHRANK, Guisela; PEDRO, Eva Neri Rubim. O enfermeiro como ser sócio-político: refletindo a visibilidade da profissão do cuidado. Acta Paul

Enferm., São Paulo, v.19, n. 1, p. 82- 87, 2006. Disponível em: $<$ http://www.scielo.br/pdf/ape/v19n1/a13v19n1>. Acesso em: 20 jan. 2017. 
PEDUZZI, Marina. Equipe multiprofissional de saúde: conceito e tipologia. Revista Saúde Pública, São Paulo, v. 35, n. 1, p. 103-9, 2001. Disponível em: <http://www.scielo.br/pdf/rsp/v35n1/4144.pdf>. Acesso em: 20 jan. 2017.

PELLON, Luiz. H. C. Tensões interculturais e os impactos nos processo saúdedoença na população Guarani Mbyá do município de Aracruz, espírito Santo. 2008. 218p. Dissertação (Programa de Pós Graduação em Enfermagem) Universidade Federal do Rio de Janeiro, Rio de Janeiro, 2008.

PEREIRA, Ingrid. D. F; LAGES, Itamar. Diretrizes curriculares para a formação de profissionais de saúde: competências ou práxis?. Trabalho, Educação e Saúde, Rio de Janeiro, v.11, n. 2, p. 319-338, maio-ago. 2013. Disponível em: <http://www.scielo.br/pdf/tes/v11n2/a04v11n2.pdf>. Acesso em: 20 jan. 2017.

PEREIRA, Pedro P. G. Limites, traduções e afetos: profissionais de saúde em contextos indígenas. Mana, Rio de Janeiro, v. 18, n. 3, p. 511-538, dez. 2012. Disponível em: <http://www.scielo.br/scielo.php?script=sci arttext\&pid=S0104>.93132012000300004\&lng=en\&nrm=iso >. Acesso em: 30 Jan. 2017.

PEREZ, Maria I. L. Competência: uma noção plástica, polissêmica e polimorfa. Revista Praxis Educacional, Vitória da Conquista, v.1, n.1, p. 57-65, 2005. Disponível em: <http://periodicos.uesb.br/index.php/praxis/article/viewFile/400/430>. Acesso em: 02 mar. 2017.

PERRENOUD, Philippe. Construir competências é virar as costas aos saberes? Pátio Revista Pedagógica, Porto Alegre, n.11, p. 15-19,1999. Disponível em $<$ https://www.unige.ch/fapse/SSE/teachers/perrenoud/php main/php 1999/1999 39. html>. Acesso em: 20 nov. 2016.

PERRENOUD, Philippe. Construindo competências: entrevista. Revista Nova Escola, n. 135, p.1-7, set. 2000. Entrevista concedida a Paola Gentile e Roberta Bencini. Disponível em:

$<$ http://smeduquedecaxias.rj.gov.br/nead/Biblioteca/Forma\%C3\%A7\%C3\%A30\%20C ontinuada/Artigos\%20Diversos/construindo\%20competencias\%20\%20In\%20Nova\%20Escola.pdf>. Acesso em: 20 nov. 20116.

PERUZZO, Pedro. P. Direitos humanos, povos indígenas e interculturalidade. Revista Videre, Dourados, v. 8, n. 15, p. 11-25, jan./jun. 2016. Disponível em: $<$ http://ojs.ufgd.edu.br/index.php/videre/article/view/5594/3136>. Acesso em 20 mar. 2017.

PIRES, Elvira. D. Divisão técnica do trabalho em saúde. In: PEREIRA, Isabel. B.; LIMA, Júlio. C. F (Org.). Dicionário da educação profissional em saúde. 2. ed. Rio de Janeiro: Escola Politécnica de Saúde Joaquim Venâncio, 2008. p. 130-135.

PRZENYCZKA, Ramone. A. et al. O paradoxo da liberdade e da autonomia nas ações do enfermeiro. Texto e Contexto Enfermagem, Florianópolis, v.21, n. 2, p. 427-431, abr./jun. 2012. Disponível em: <http://www.scielo.br/pdf/tce/v21n2/a22v21n2>. Acesso em: 15 jan. 2017.

RAMOS, Alcida Rita. O índio Hiper-Real. Revista Brasileira de Ciências Sociais, São Paulo, v. 28, n.10, p. 5-14, 1995. Disponível em: $<$ http://www.anpocs.org.br/portal/publicacoes/rbcs 00 28/rbcs28 01.htm>. Acesso em: 20 jan. 2017. 
RAMOS, Natália. Comunicação, cultura e interculturalidade: para uma comunicação intercultural. Revista Portuguesa de Pedagogia, Lisboa, n. 2, 2001. Disponível em: $<$ https://repositorioaberto.uab.pt/bitstream/10400.2/5839/1/Ramos\%20\%282001\%29. \%20Comunica\%C3\%A7\%C3\%A30\%20cultura\%20e\%20interculturalidade.pdf $>$. Acesso em: 10 fev. 2017.

$\mathrm{RECH}$, Patrícia. Supervisão na formação profissional de agentes indígenas de saúde no parque Indígena do Xingu. 2008. 200 p. Dissertação (Mestrado em Serviços de Saúde Pública) - Faculdade de Saúde Pública, Universidade de São Paulo, São Paulo, 2008.

ROCHA, Esron. S. C. Uma etnografia das práticas sanitárias no Distrito Sanitário Especial Indígena do Rio Negro-Noroeste do Amazonas. 2007. 179 p. Dissertação (Mestrado em Sociedade e Cultura na Amazônia) - Universidade Federal do Amazonas, Manaus, 2007.

RODRIGUES, Douglas. A. Proteção e Assistência à Saúde dos Povos Indígenas Isolados e de Recente Contato no Brasil. São Paulo: OTCA, 2014.

RODRIGUES, Douglas. A; MENDONÇA, Sofia. B. M. de. Política Indigenista de Saúde. São Paulo: UNIFESP, 2015. Texto de Apoio, disciplina de Política e Organização dos Serviços de Saúde Indígena, Curso de Especialização em Saúde Indígena à distância - UNASUS/UNIFESP. Acesso restrito.

RODRIGUES, Douglas. A. et al. A atenção diferenciada em saúde indígena: considerações iniciais. São Paulo: UNIFESP, 2015. Texto de Apoio, disciplina de Política e Organização dos Serviços de Saúde Indígena, Curso de Especialização em Saúde Indígena à distância - UNASUS/UNIFESP. Acesso restrito.

ROUANET, Sérgio. P. Ética e antropologia. Estudos Avançados, São Paulo, v. 4, n. 10, p. 111-150, Dez. 1990. Disponível em:

<http://www.scielo.br/pdf/ea/v4n10/v4n10a06.pdf>. Acesso em: 20 fev. 2017.

SANNA, Maria. C. Os processos de trabalho em enfermagem. Revista Brasileira de Enfermagem, Brasília, v. 60, n. 2, p. 221-224, 2007. Disponível em:

$<$ http://www.scielo.br/pdf/reben/v60n2/a17v60n2.pdf $>$. Acesso em: 15 nov. 2016.

SANTOS, Ricardo. V; COIMBRA JR, Carlos. E. A. Cenários e tendências da saúde e da epidemiologia dos povos indígenas no Brasil. In: SANTOS, Ricardo. V; COIMBRA JR, Carlos. E. A; ESCOBAR, Ana Lúcia. (Org.) Epidemiologia e saúde dos povos indígenas no Brasil. Rio de Janeiro, FIOCRUZ, 2003. p. 13-48.

SANTOS, Ricardo. V; COIMBRA Jr, Carlos. E. A.; CARDOSO, Andrey. M. Povos indígenas no Brasil. In: BARROS, Denise. C; OLIVEIRA E SILVA, Denise; GUGELMIN, Silvia. A. (Org.). Vigilância Alimentar e Nutricional para a Saúde Indígena. Rio de Janeiro: Fiocruz, 2007, p. 21-45.

SAUPE, Rosita. et al. Conceito de competência: validação por profissionais de saúde. Saúde em Revista, Piracicaba, v. 8, n. 18, p.31-37, 2006. Disponível em: $<$ http://189.28.128.100/nutricao/docs/Enpacs/pesquisaArtigos/conceito de compete ncia validacao por prof saude 2006.pdf>. Acesso em: 15 jan. 2017.

SESAI - Secretaria Especial de Saúde Indígena. 5a Conferência Nacional de Saúde indígena: relatório final. Brasília, DF, 2014. 
SILVA, Cleonice. B. da. Profissionais de saúde em contexto indígena: Os desafios para uma atuação intercultural e dialógica. Revista de Antropologia, Brasília, n. 6, p. 3-36, 2013. Disponível em:

$<$ http://revista.antropos.com.br/downloads/dez2013/Artigo-1-Profissionais-de-saudeem-contexto-indigena-Cleonice-Barbosa-da-Silva.pdf>. Acesso em: 20 nov. 2016.

SILVA, Cristina. D. da. Cotidiano, saúde e política: uma etnografia dos profissionais de saúde indígena. 2010. 276p. Tese (Doutorado em Antropologia) - Universidade de Brasília, Brasília, 2010.

SILVA, Cristina. D. da. De improvisos e Cuidados: a saúde indígena e o campo da enfermagem. In: TEIXEIRA, C.C; GARNELO, L. (Org.). Saúde indígena em perspectiva: explorando suas matrizes históricas e ideológicas. Rio de Janeiro: Fiocruz, 2014. p.181-212.

SILVA, S. de C. R; SCHIRLO, A. C. Teoria da aprendizagem significativa de Ausubel: reflexões para o ensino de física ante a nova realidade social. Imagens da Educação, v. 4, n. 1, p. 36-42, 2014. Disponível em:

$<$ http://periodicos.uem.br/ojs/index.php/lmagensEduc/article/viewFile/22694/PDF>. Acesso em: 05 mar. 2017.

SIQUEIRA-BATISTA, Rodrigo. et al. Educação e competências para o SUS: é possível pensar alternativas à (s) lógica (s) do capitalismo tardio?. Revista Ciência e Saúde Coletiva, Rio de Janeiro, v. 18, n. 1, p.159-170, jan. 2013. Disponível em: $<$ http://www.redalyc.org/pdf/630/63025587017.pdf>. Acesso em: 10 fev. 2017.

TREZZA, Maria. C. A. F; DOS SANTOS, Regina Maria; LEITE, Joséte Luzia. Enfermagem como prática social: um exercício de reflexão. Revista Brasileira de Enfermagem, Brasília, DF, v. 7, n. 6, p. 904-908, 2008. Disponível em: $<$ http://www.scielo.br/pdf/reben/v61n6/a19v61n6.pdf >. Acesso em: 10 jan. 2016.

UNESCO. Investir na diversidade cultural e no diálogo intercultural: relatório mundial. 2009.

VERANI, Cibele. B. L. A política de saúde do índio e a organização dos serviços no Brasil. Política indigenista, movimentos étnicos e estados nacionais. Políticas públicas, políticas indigenistas e organizações indígenas. Belém: Boletim do Museu Paraense Emílio Goeldi, série antropologia, v.15, n. 2, p.171-192, 1999.

VILLAS BÔAS, O. Trinta e cinco anos de assistência e pesquisa: a Escola Paulista de Medicina e o Parque Indígena do Xingu. In: BARUZZI, Roberto. G; JUNQUEIRA, Carmem. (Org.). Parque Indígena do Xingu: saúde, cultura e história. São Paulo: Terra Virgem, 2005. p. 49-57.

VILELAS, José. M.S; JANEIRO, Sandra I. D. Transculturalidade: o enfermeiro com competência cultural. Revista Mineira de Enfermagem, Belo Horizonte, v. 16, n. 1, p. 120-127, 2012. Disponível em: <http://www.reme.org.br/artigo/detalhes/509>. Acesso em: 15 out. 2015. 
ANEXOS

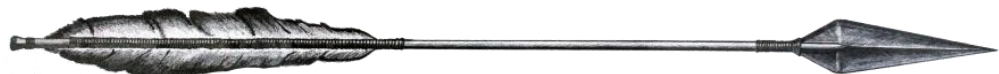




\section{ANEXOS}

Anexo A - Roteiro para entrevista semiestruturada

INSTRUMENTO PARA IDENTIFICAÇÄO DOS PERTICIPANTES E ROTEIRO PARA ENTREVISTA SEMI ESTRUTURADA

Pesquisa: "O trabalho do enfermeiro na Saúde Indígena: desenvolvendo competências para a atuação no contexto intercultural."

Autora: Juliana Cláudia Leal Martins

Dados objetivos

Entrevista $\mathrm{N}^{\circ}$

Data I

Idade Sexo

Onde mora

Tempo de duração e ano de conclusão da graduação

Instituição da graduação

Pós graduação

Instituição da pós graduação

Trajetória profissional (instituição, tipo de vínculo, público/privado, atividade profissional)

Tempo de atuação na saúde indígena (meses)

Tempo de trabalho no DSEl Xingu (meses)

Função atual

Tempo de trabalho como integrante de EMSI

Roteiro para entrevista

1. Como foi o seu primeiro dia de trabalho em campo? O que ficou de mais marcante sobre os acontecimentos daquele dia?

- O primeiro impacto do contato com o campo (os indígenas, os profissionais, geografia, espaço físico, alimentação, instalações】 
- O que era igual e o que era diferente entre o imaginado e o real?

2. Como você veio trabalhar na saúde indígena?

- Quais as principais motivações? (contato prévio com o campo, financeira, oportunidade de emprego, experiência diferente, proximidade com local de moradia)

3. Como você imaginava que ia ser este trabalho?

- O que o profissional "trouxe" para este trabalho?

- Já tinha ouvido falar do trabalho na saúde indígena?

- Conhece outros profissionais que estavam inseridos neste trabalho?

- O que sabia sobre os indígenas?

- O que sabia sobre o Parque do Xingu?

- Como ele pensava que ia ser atuação profissional dele, a relação com os indígenas, o trabalho de campo.

4. Você teve conteúdos sobre saúde indígena na graduação?

- Em algum momento teve contato com a temática indígena na graduação?

- E na vida escolar?

- Que conceitos e concepções carrega sobre indígenas a partir da formação escolar?

5. A medida que você foi prosseguindo no trabalho o que você identificou que precisava aprender?

- Quais foram as dificuldades? O que você sentia falta?

- As maiores dificuldades são profissionais ou pessoais?

- Como elas vão aparecendo? Como vai percebendo essas dificuldades.

- Habilidades, conhecimentos e atitudes demandados.

6. Como você foi aprendendo a atuar na saúde indígena?

- Quais estratégias o profissional utilizou?

- A quem e/ou a que ele recorreu para aprender?

7. A permanência dentro de área colabora o seu aprendizado?

- Você consegue aprender com o dia a dia do trabalho?

- Quais outros momentos você aprende além das atividades do trabalho 
- Quais são os espaços do aprendizado?

- Quem colabora/participa do seu aprendizado?

8. A partir da sua experiência, o que você considera necessário ser ofertado ao profissional enfermeiro que vai trabalhar dentro de área indígena?

- Conhecimentos

- Retaguarda para o trabalho

9. Qual o seu maior aprendizado nesta experiência de trabalho na saúde indígena?

10. Sobre o que conversamos, você gostaria de acrescentar alguma coisa? 
Anexo B - Percurso adotado para a definição dos temas de análise

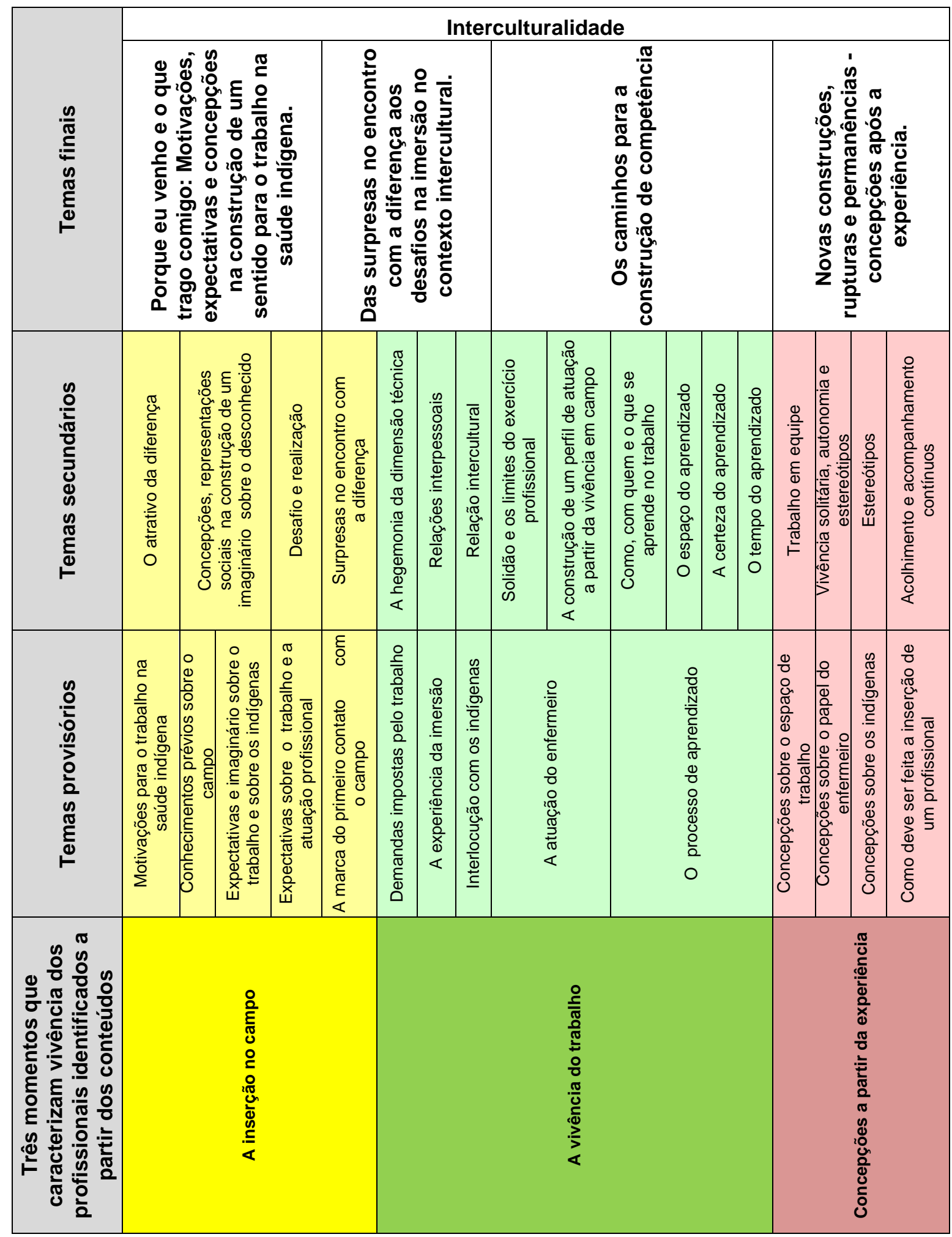




\section{Anexo C - Termo de anuência do Conselho Distrital de Saúde Indígena do DSEI Xingu}

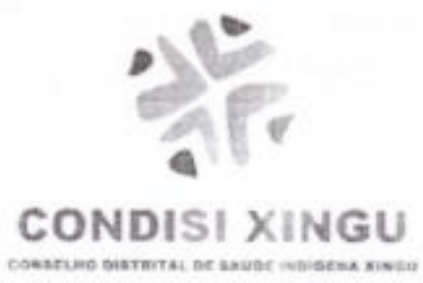

Carta de aprovação do Conselho Distrital de Saúde do Xingu

Termo de anuência do Conselho Distrital de Saúde do Xingu

Declaramos que estamos cientes e aprovamos a realizaçăo da pesquisa: "O trabalho do enfermeiro na Saúde Indigena: desenvolvendo competências para o trabalho no contexto intercultural" de responsabilidade da aluna Juliana Cláudia Leal Martins do Programa de Pós Graduaçăo da Faculdade de Saúde Pública da Universidade de Sáo Paulo, O trabalho nos foi enviado com os devidos esclarecimentos prestados. Ficou claro que a pesquisa tem como público alvo os enfermeiros que integram ou já integraram as equipes de campo. năo envolvendo a participação de indigenas. Ficou claro também que a participaçāo dos profissionais enfermeiros è voluntária e só será efetivada mediante anuência individual expressa pela assinatura do Termo de Esclarecimento Livre e Esclarecido.

Após a conclusão, os resultados deste estudo serão encaminhados para o Distrito Sanitário Especial Indigena Xingu, para o conselho Distrital de Saúde deste DSEI, para os profissionais que participarem do estudo e para a conveniada responsável pela contratação dos profissionais deste DSEI.

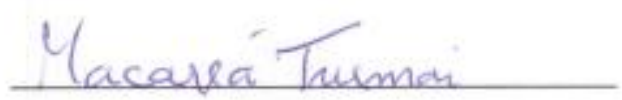

Data $105 / 02$ 1 CCIE

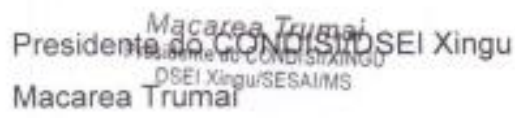

Macarea Trei Xinguisesaims 


\section{Anexo D - Termo de Consentimento Livre e Esclarecido}

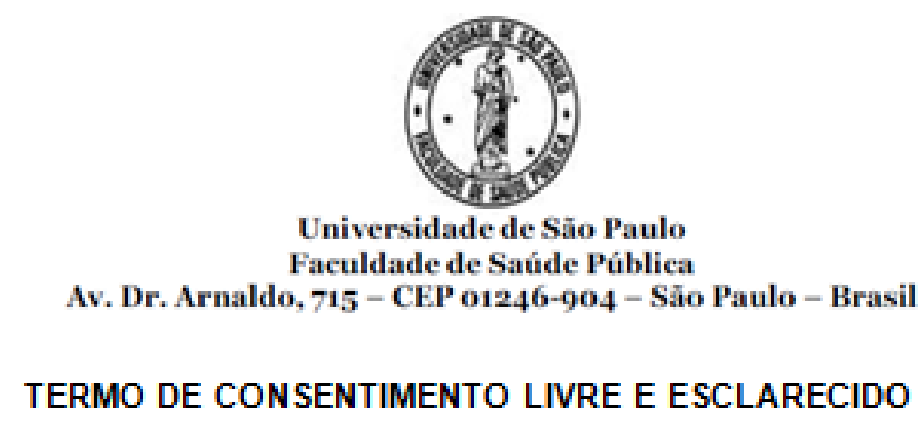

( $1^{2}$ via do sujeito da pesquisa/ $2^{2}$ via do pesquisador)

1. Dados da pesquisa

Você está sendo convidado para participar do estudo: "O trabalho do enfermeiro na Saúde Indígena: desenvolvendo competências para a atuação no contexto intercultural."

O objetivo desse estudo é compreender como o profissional enfermeiro aprende a desenvolver sua prática profissional em um contexto de trabalho tão específico como é o da atenção à saúde dos povos indígenas. $O$ estudo buscará analisar e refletir sobre as possibilidades de exploração do cotidiano de trabalho desse profissional dentro de área indígena como um espaço de aprendizagem.

Sua colaboração será de grande importância para a realização desse trabalho, motivo pelo qual solicito sua participação.

A sua participação é voluntária e consiste em uma entrevista (semi estruturada) abordando questões relativas ao tema do estudo com duração aproximada de 45 minutos. A entrevista que será gravada e posteriormente transcrita e armazenada em arquivos digitais.

Será garantido que seu nome e as suas informações permaneçam em sigilo (segredo). Qualquer dado que possa identificá-lo será omitido na divulgação dos resultados da pesquisa e o material armazenado em local seguro.

Você poderá fazer todas as perguntas que achar necessárias para o esclarecimento de dúvidas em qualquer momento. 
O risco ao qual você pode estar eventualmente submetido com a participação neste estudo é o de sentir algum constrangimento durante a realização da entrevista. Caso isso ocorra, você poderá se recusar a responder perguntas ou deixar de participar do estudo a qualquer momento sem que isto te traga qualquer tipo de prejuízo.

Os benefícios que você terá com a participação neste estudo são indiretos e estão relacionados aos resultados da pesquisa como: melhor compreensão da prática da enfermagem na saúde indígena, sobre o processo de aprendizado em serviço e as implicações para a formulação de estratégias de formação desenvolvidas dentro das áreas pelo DSEI.

Declaro que não haverá despesas pessoais (gastos) para você em qualquer fase do estudo e nem compensação financeira (pagamento) para sua participação.

Ao final do estudo, se for de seu interesse, terá livre acesso ao conteúdo da mesma, podendo discuti-lo com a pesquisadora.

Os resultados do estudo serão apresentados e discutidos na dissertação. Além disso, poderão ser apresentados em eventos acadêmicos e científicos e publicados em periódicos e revistas científicas.

Desde já agradeço a sua colaboração e me coloco à disposição.

Informações dos Responsáveis pelo acompanhamento da pesquisa para contato, em caso de dúvidas:

Nome: Juliana Cláudia Leal Martins

Endereço: Rua Dr. Nicolau de Souza Queirós $\quad$ No: 709 APTO: 22

Bairro: Vila Mariana Cidade: São Paulo CEP: 04105-001

Telefones: (11) 982585581 (11) 55752052

Email: icleal@usp.br

Nome: Comitê de Ética em Pesquisa da Faculdade de Saúde Pública da Universidade de São Paulo 
Bairro: Cerqueira César Cidade: São Paulo

CEP: 01246-904

Telefone: (11) 3061-7779

Email: coep@fsp.usp.br

\section{Consentimento pós-esclarecido}

Acredito ter sido informado o suficiente sobre as palavras que li ou que foram lidas para mim, descrevendo o estudo sobre "O trabalho do enfermeiro na Saúde Indígena: desenvolvendo competências para a atuação no contexto intercultural."

Ficaram claros para mim quais os objetivos do estudo, os procedimentos que serão feitos, as garantias de segredo e de esclarecimentos permanentes. Ficou claro também que não terei gastos ou receberei pagamento para participar.

Concordo em participar deste estudo e poderei retirar minha autorização a qualquer momento, antes, durante ou depois da entrevista, sem penalidade ou prejuízo.

Declaro que, após ter entendido o que me foi explicado, aceito participar do estudo.

de de

Assinatura do Entrevistado

Declaro que obtive de forma apropriada e voluntária o Consentimento Livre e Esclarecido deste entrevistado para participação neste estudo.

Juliana Cláudia Leal Martins 


\title{
Anexo E - Autorização para uso de dados do DSEI Xingu
}

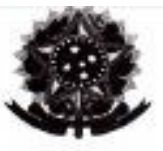 \\ Ministério da Saúde \\ Secretaria Especial de Saúde Indigena \\ Distrito Sanitário Especial Indigena Xingu \\ Avenida Goids n.97, Bairo Jardim Tropical-Cansrana/MT - CEP: 78.640-000 \\ EMAL: drabingy sesainesaude goy to
}

Termo de autorizaçăo para uso de dados

O presente termo de consentimento refere-se à pesquisa intitulada: 'O trabalho do enfermeiro na Saúde Indigena: desenvolvendo competências para a atuaçăo no contexto intercultural." $O$ estudo objetiva analisar e refletir sobre as possibilidades de exploraçâo do cotidiano de trabalho como um espaço de aprendizagem para que o enfermeiro consiga desenvolver a sua prática profissional voltada para a atuação dentro das terras indigenas. Este estudo náo apresenta quaisquer riscos para as comunidades do Parque Indigena do Xingu.

Após devidamente esclarecidos, o Coordenador do Distrito Sanitário Especial Indigena Xingu (DSEI Xingu) e o Coordenador da Divisâo de Atençăo à Saúde Indigena (DIASI) autorizam Juliana Cláudia leal Martins a utilizar informaçōes relacionadas a força de trabalho do DSEI Xingu para realizaçāo do estudo.

Canarana/MT - DSEI Xingu, 16 de Fevereiro de 2016.

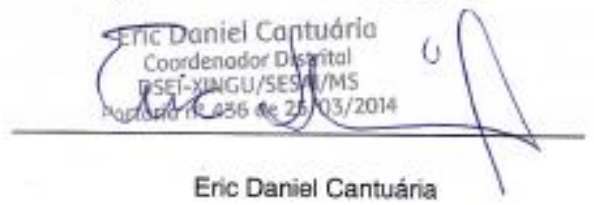

Coordenador do DSEI Xingu

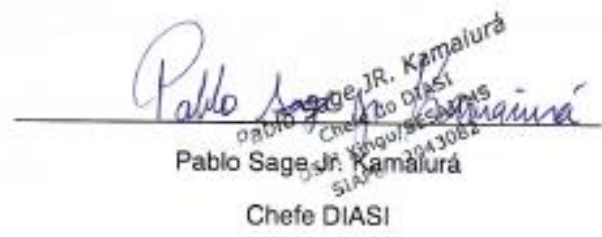




\title{
Anexo F - Autorização para utilização de dados do Projeto Xingu/ UNIFESP
}

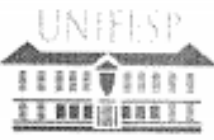

\author{
UNIVERSIDADE FEDERAL DE SÃO PAULO \\ Escola Paulista de Medicina \\ Departamento de Medicina Preventiva \\ HOSPITAL SÄO PAULO \\ Ambulatório do Índio - Projeto Xingu
}

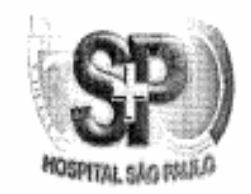

Termo de autorizaçăo para uso de dados

O presente termo de consentimento refere-se ao projeto de pesquisa intitulado "O trabalho do enfermeiro na Saúde Indígena: desenvolvendo competências para a atuação no contexto intercultural" que pretende analisar e refletir sobre as possibilidades de exploraçăo do cotidiano de trabalho como um espaço de aprendizagem para que o enfermeiro consiga desenvolver a sua prática profissional voltada para a atuaçăo dentro das terras indigenas.

Após devidamente esclarecido, o chefe da Unidade de Saúde e Meio Ambiente do Departamento de Medicina Preventiva da EPM/UNIFESP autoriza a aluna Juliana Cláudia leal Martins a utilizar dados de relatórios técnicos do Projeto Xingu para complementar o estudo vinculado ao Programa de pós graduação da Faculdade de Saúde Pública da Universidade de Săo Paulo.

Confirmo a autorizaçăo para a utilização de dados dos relatórios técnicos do Projeto Xingu/UNIFESP.

Säo Paulo 27 de Janeiro de 2016.

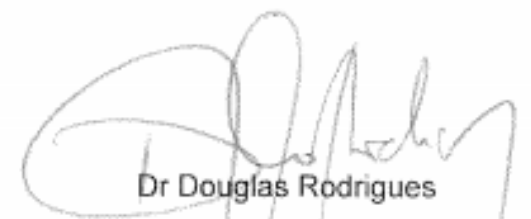

Chefe da Unidade de Saúde e Meio Ambiente

Departamento de Medicina Preventiva EPM/UNIFESP 